Historic, Archive Document

Do not assume content reflects current scientific knowledge, policies, or practices. 



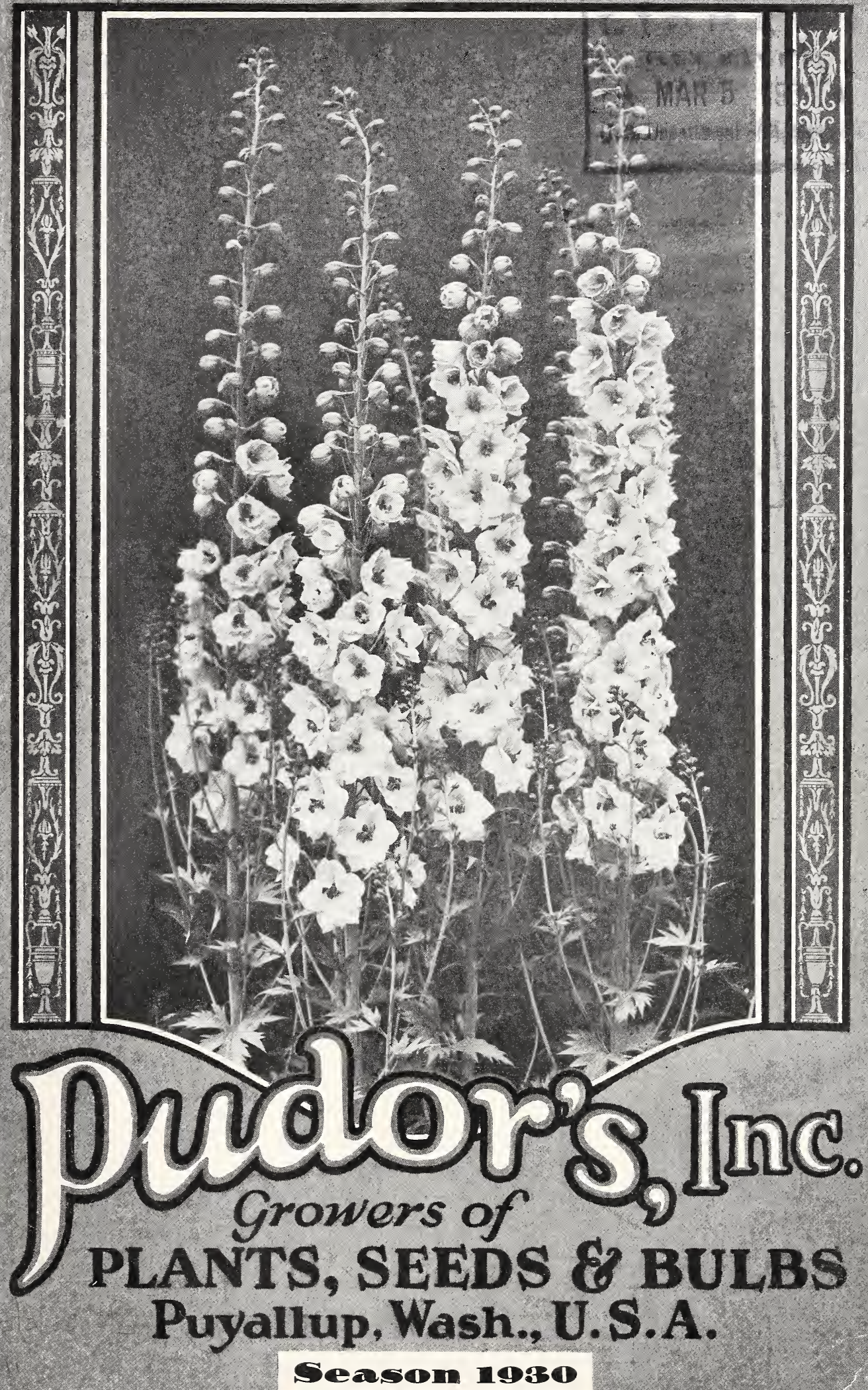




\section{TERMS-RULES}

First: No Plant order is filled for less than $\$ 1.50$, unless you pay 25 cents extra for packing and postage. No seed order is filled for less than 25 cents.

Second: We pay the postage on all mail orders, but plants on which we pay the postage are of necessity smaller than those upon which you are willing to pay the postage or have sent by express. You understand that we cannot pay out the biggest part of our profit for postage. Therefore, if you are willing to pay the express charges, or will pay 10 per cent on your order towards the postage, we gladly send you larger plants, except in cases of rare and expensive plants, of which you can expect only small divisions at the best.

Third: We do not open accounts-we are too busy, and bookkeeping is too expensive. Neither do we send plants or seeds C. O. D. unless one half is paid with the order.

Send Money Order, Express Order, Check or Draft.

If you send currency, have your letter registered; we assume no responsibility if money is sent in an ordinary letter.

If you must send stamps, please do not send more than $50 \mathrm{c}$ worth.

Fourth: All stock is offered subject to being unsold on receipt of order; if stock ordered is not available, unless you have named some substitutes, we will return your money-we do not substitute.

Fifth: We guarantee our plants and seeds to be true to name; if through some error on our part the plant turns out otherwise, we will replace it free of charge; this, however, does not apply to seedlings that have not bloomed yet and of which certain colors are ordered; we can give no warranty, express or implied, that the progeny will be true to the parent color; this applies particularly to Delphiniums, Columbines, Lupins and Oriental Poppies.

Sixth: The choice flower seeds offered herein are absolutely good and fresh and with reasonable care and skill on your part a large germination should be obtained in every case, with some exceptions, however, of a few notable bad germinators. Some seeds lie in the ground for a long time, some all Winter, and then come up strong in the Spring. With good care, all flower seeds are as good in the Spring as they were in the fall. Some people have the notion that Delphinium seeds lose all their strength by Spring. This is absolutely not the case; these seeds, if sown with ordinary care, are just as good for Spring sowing as they were in the Fall, the only difference being that instead of germinating in 10 days it might take them 3 or 4 weeks. We sow many ounces as late as April 15th; thirty days later we have a beautiful stand of tens of thousands of seedlings, the long rows looking like a wide green ribbon.

Seven:h: We are not responsible for delays in the mails, and particularly not if the stock is held up through Quarantine regulations. If your are so unfortunate as to live in a State that has stringent plant laws and where plants are sent, after being received at your Post Office, to a central inspection point, often many miles away, then opened up, handled, perhaps fumigated, and after such treatment carelessly re-packed and returned to your Post Office, often causing days of delays. We would advise shipments by express.

A complete index of all plants and seeds will be found on last page.

We want to thank all customers for their patronage in the past. On the basis of service and satisfaction we solicit your orders, large or small.

PUDOR'S, INC.

ATTENTION-THIS CATALOG CANCELS ALL PREVIOUS CATALOGS 


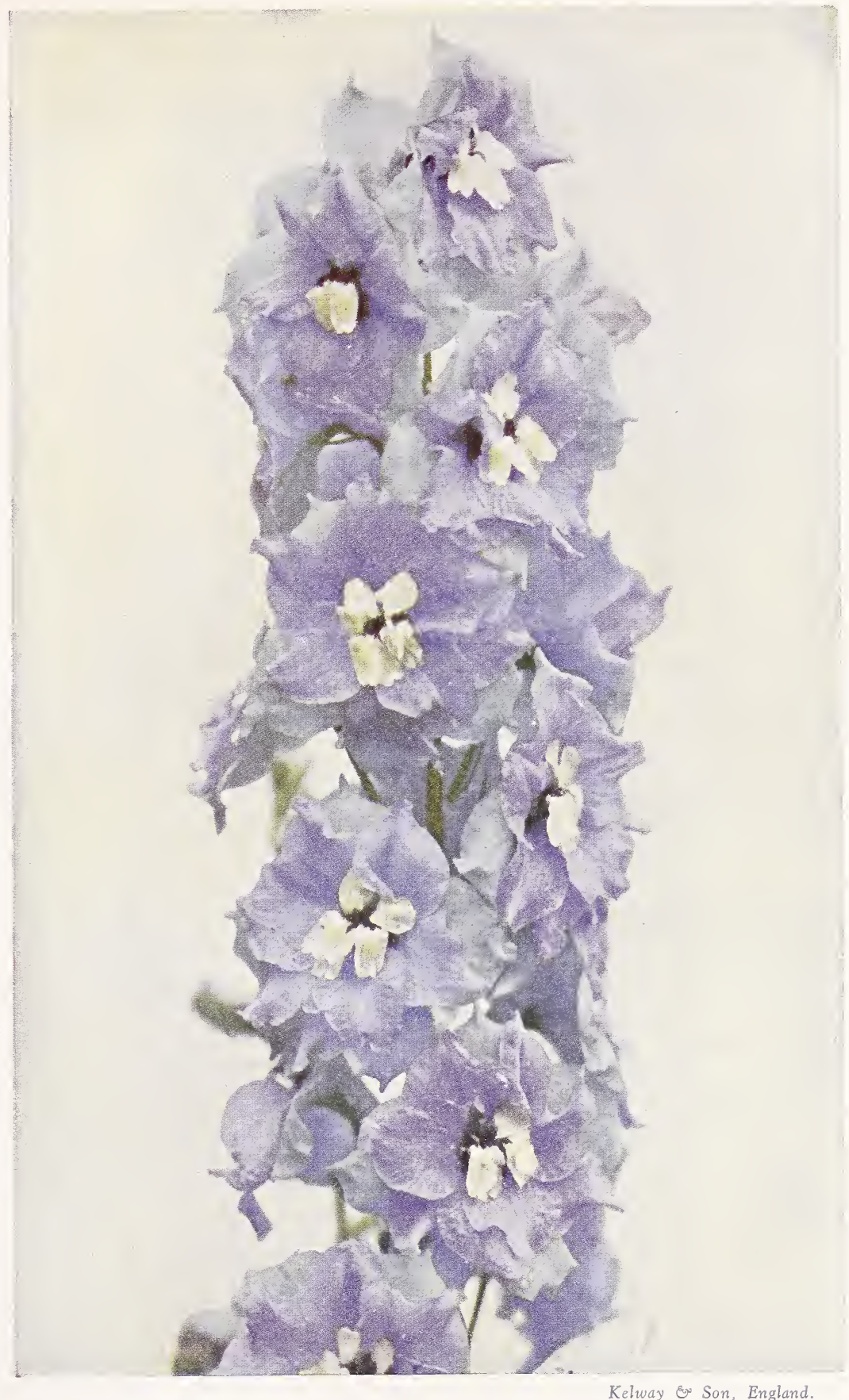

\section{GOLD MEDAL DELPHINIUM: MRS. JAMES KELWAY}

This color photo of DELPHINIUM is about half natural size, and is a portion of a 4-foot spike of flower.

Mrs. James Kelway. We selected this English named Delphinium by Kelway's as the best outstanding double variety of English origin. The color of the outside petals is a beautiful pale sky-blue with a layer of orchid pink inner petals with a large white eye or bee. We have contracted for all of the seeds from the originators. 3 pkts. for $\$ 2.50$; per pkt. 



\section{Cultural Directions for the Perennial Garden}

\section{Extract from a paper read at the recent annual convention of The Canadian Horticultural Association by W. J. Potter, Parks Department, Toronto, Ont.}

The most beautifully wrought bedding plant scheme cannot compare with a well-designed perennial garden, with its daily surprises and new faces to welcome us. One week it is a riot of color and the next something different. lt presents an ever-changing succession, commencing before the winter snows have melted, until Jack Frost calls a halt in the fall. This is one reason why we should grow more of this class of plants. Another reason is that they fill the bill in every size of a garden, from the capacity of a few dozens, for the cottage, to the broad acres of the millionaire.

The preparation of the soil for a planting of perennials should be most thorough in every detail, if we expect results that shall excel. The work should be of a permanent character. The plan that 1 have generally adopted l find works well.

Prepare the beds in the fall by trenching or digging two spade $s$ deep. This breaks up the sub-soil. It should be dug and left in a rough condition, at the same time incorporating plenty of good rotten manure, or half-rotted leaves, or both, if the soil is very heavy. This makes the best medium for growing perennials. Give a good application of charcoal, peat moss, fibre or, b e t t e r still, plenty of good, tough sod. T h e s e materials will act as mechanical agents to the soil, as well as give fertility, and at the same time will tend to increase its effectiveness as a drought resister, and a storehouse for plant food for many years.

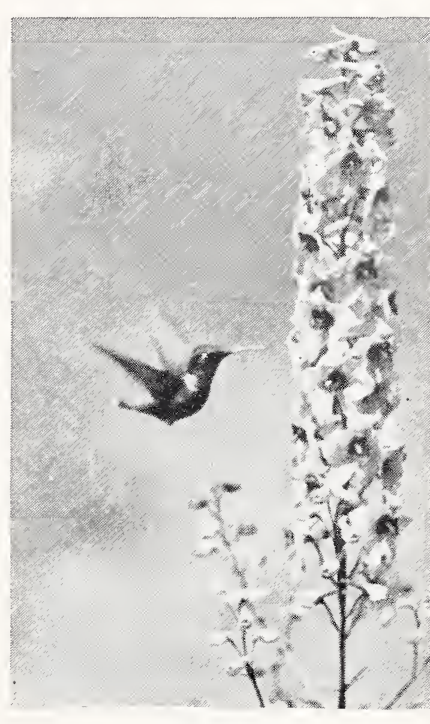

TRADE MARK

$\mathrm{D}$ e e p cultivation is very essential as many of our best perennials are deep-rooting; for example, th e Leguminose, Malvaceae, Campanulas, and many others. Nothing suits them better than to get down to the cool reservoirs of moisture and air space during the parching months of July and August. The extra trouble of deep cultivation will be amply repaid in the extra quantity and quality of the flowers. In addition they will require less attention as to watering, etc., especially if we have to de$p$ e $n d$ on the rainfall. T re n c hing not only opens up the soil and allows freedom of root action, but also drains the soil in winter, and renders it moist in summer. The action on the pores of the soil is similar to the action of warm air in contact with a cooler surface of body.

If the ground is of a very sandy nature it is better to neutralize it by the action of cow manue (if procurable). Heavy clay loam with the sod left on is preferable. Wood ashes or lime applied at the time of preparation is also good, as it has a binding effect on the soil, and being very "leachy," heavy mulching at all times is necessary for the best success. In summer it prevents too rapid evaporation and provides a constant stimulus. It acts also as a protection in winter.

I am rather in favor of nitrogenous manures for perennials, especially in the growing of the heavier varieties, although it is necessary to give a liberal dressing of bone meal or granulated bone annually, as leguminous and woody plants depend on the lime salts and phosphoric acid contained therein. On the other hand, there are some plants that do not like lime, e. g., the Foxglove, but they are few in number.

There are two general methods in the planting of a perennial garden. The first is by arrangement of colors for certain sections or divisions. Of course, in each case the aim is to have continuity of bloom for the entire season, so arrange the height, natural position, etc. This method might suit those who are partial to certain colors and shades and is easily accomplished. 
Color planting is more suitable for large gardens, where the eye rests on the whole or greater part of the scheme. It also includes the choice and use of two colors or combinations, such as pink and blue (light), cream and purple, golden yellow and deep blue, or orange and medium blue; or a gradual blending down from an intense color, using several intermediate shades. The yellow and orange shades always look well and if separated in good generous blocks, cannot help but be effective. Blocks of white flowers or green ornamental foliage will act as a foil where it is necessary to use strong colors in heavy masses, reds and scarlets for example, that if both meet the eye at the same time. The blue Delphiniums, white and pink Hollyhocks afford an example of good tones, but keep the reds and maroons away. Gypsophila and purple Delphiniums form an aesthetic combination. Place Golden Coreopsis against heavy foliage and deep shadows. Plant Foxglove among an underground of dwarfer material or among evergreens in groups. The composite flowers offer many delightful combinations. One cannot err in their use, as the colors, for the most part, can be called relative or harmonious. Examples include Heliopsis and Calimeris incisa, Stokesia and Shasta Daisy. These can be used also with Golden Anthemis. Rudbeckia purpurea and Rudbeckia fulgida or subtomentosa harmonize, and so on "ad infinitum."

Collections of Phlox show off to much advantage if separated as to color, the scarlets from the magentas and pinks from the purples. Use the white forms between.

The second method of planting may appeal to those who want to form collections without regard to color arrangement. If so, use plenty of green foliage as a foil and background. This method is the planting of each genera or family in separate masses or irregular bays in conformity with the size and shape of that portion of the bed to be planted. When following this method, make a sketch or drawing to scale and have the framework laid out first with the space alloted to each group. Then plant evergreen shrubs at vantage points. These not only act as foils to certain colors and forms, but also afford shelter in winter from cutting winds and in summer from hot sun for shade-loving plants.

There are many genera which will thus make a continuous show of bloom by judicious placing and the use of proportionate number. Take Veronica for example. The first one blooms in the spring, and so on till fall, without a blank. Phlox are the same, starting with P. ovata, and followed by Arendsii, suffiruticosa, and decussata, giving an unending succession till October. Rudbeckia, Helianthus, Spiraea, Aconitum, Campanula, Helenium, lnula, Pentstemon, Lychnis, Lilium, Aquilegia, Gypsophila, and many other families not including continuous bloomers, can be used in this way. If by chance there happens to be any blank spaces, any of the continuous bloomers in the list fill the bill.

Propagation may be done in a number of ways. The most generally adopted method is by seeds. These should be sown early enough to form good, strong plants by October so as to enable them to stand the winter. About June will usually suffice for many. l prefer sowing most everything in the spring, as it takes a long time for many to form good crowns, as it is better to err on the side of size than lose your stock through the winter. Phlox are better sown in the fall as soon as ripe. This is true also of few other hard seeds, as many will not keep, such as Aquilegia, Myosotis and Primula. These must be sown as soon as possible. This method applies only to stocks which come true from seed or with which there is no regard for mixture. Any choice varieties, such as Phlox, Delphinium, Gaillardia, etc., are better raised from cuttings or divisions.

Cuttings are made early in the spring. A frame or greenhouse is a necessary adjunct for the purpose. By wintering such stocks inside a cold house, they can be raised wholesale, and indeed many will bloom the first season. These cuttings should be taken as short as possible on the side growth or when first starting to grow. Others can be multiplied from the roots, as having running fleshy roots they can be cut up in small pieces, for example, Gaillardia, Dicentra, Lythrum, Peony, Poppies, etc.

Many perennials can be increased by a system of layers without much trouble, including the dwarfer cushion plants, such as Arabis, Campanula carpatica, Dianthus and others. All that is necessary to do is to cover the plants with sand or sandy soil so as to form a mound, but not so thick as to bury the plant. Merely fill up 
the intervals between the leaves and stems. Some plants are better propagated by earthing up the stems in a similar way, for example, tree Ponies, and some other of a semi-shrubby nature.

The majority of herbaceous perennials are easily increased in smaller quantities by simple divisions of the roots. Those which have a heavy mass of fibrous roots can be increased in the fall. Indeed, this method of dividing the roots should be carried out every few years, as the quality is better. If this is neglected, the clumps get hollow and woody in many cases and are liable to run out. These include Pyrethrum, Delphiniums, Phlox, Pentstemon, Platycodon, Aquilegia, Aster and a host of others. A constant keeping up of the utmost vigor of your plants is essential both for quality and because they are then less liable to suffer from insect attacks.

It is not the intensity of our cold winters that ruins many plants, but the dry, strong winds in early spring, as well as the fact that water remains on the crowns and forms ice, thus suffocating them. To avoid much of this trouble see that your border is well drained and encourage as much of nature's covering-snow-as possible. To this end do not clean the border off too clean and bare in the fall; in fact, no more than is necessary. The more material that is left on in the way of a rough coating of leaves, etc., the more snow is liable to find a lodgment. In the case of evergreen plants, 1 find that pieces of hemlock or spruce branches around them help wonderfully. Do not cover these evergreen plants with a heavy mulch, as it will do more harm than good. They need air at all times.

\section{No Garden is Complete Without a Liberal Planting of Irises}

\section{PLANT THEM IN FEBRUARY, MARCH AND APRIL AND AGAIN FROM JULY ON TO OCTOBER FIRST}

We grow many acres of Iris, a careful selection of over 250 of the world's best Garden Iris, constantly adding to our collection. Large estates desiring to make large plantings of either the best old or the new creations, we are in a position to supply them by the hundred or even thousand at attractive prices.

The prices of nearly all the new, meritorious varieties, such as Ambassadeur, Ballerine, Dream, Gaudichau, Lord of June, Lady Foster, Lent A. Williams, Ann Page, Morning Splendor, and others in that class, have been reduced again.

We issue a very comprehensive Iris catalog, really a manual, comprising some 40 pages, and including valuable treatises, an elaborate color classification, and many illustrations; it lists in detail all of the best old garden varietise, and most of the best new ones, as well as scores of Siberian, Oriental, Japanese, Dutch, Spanish and many other Iris species. The Manual is free to prospective customers; from others a silver dime remittance would be greatly appreciated The cost is more than that.

\section{EIGHT NEW MAGNIFICENT NEW IRISES. DO YOU KNOW THEM?}

Mr. Pilkington, treasurer of The lris Society of England, whose interesting appraisals of both the newer English and American irises have appeared in former bulletins sends more interesting comment. "Asia," says Mr. Pilkington, "we consider very fine here." Mr. Sam Burchfield of Ann Arbor rates Asia at 1,000,000. It is one of eight irises I feel that I should insist on having no matter what happened in the iris world,-Ambassadeur, Asia, Ballerine, Mme. Gaudichau, Princess Beatrice, Prospero, Magnifica, and Mlle. Schwartz. I should insist upon Mlle. Schwartz as a companion to illuminate the rich tones of Ambassadeur, until Miss Sturtevant gives us a yellow Caterina or Canopus, which might be even better.

HAVE YOU A COPY OF OUR IRIS MANUAL? 


\section{NOVELTIES AND RECENT INTRODUCTIONS Per Pkt.}

Aster Farreri. The plant commences to flower about the end of April and continues throughout May and June. It is perfectly hardy and of very vigorous growth. The beauty of the flower, the ray petalsl of which a lovely soft tone of violet mauve, is greatly enhanced by a large goldenorange disc. This combination of color as can well be imagined, gives a most wonderful effect. In diameter the flowers are from $2 \frac{1}{2}$ ins. to 3 ins. across, and each plant carries twenty to thirty flowers on long,

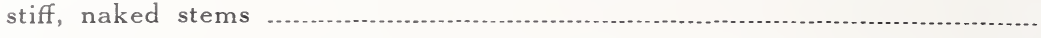

Aster Delavayi. An extremely beautiful Chinese species, close tufts of olivegreen foliage, stout naked stems bearing an exceptionally large solitary flower; the ray florets are very thin and inclined to twist; a delightful shade of lavender-blue with a conspicuous jet-black disc. It is very curious and before the flower fully develops the ray florets tie themselves across the black disc in a most conspicuous and charming manner. We are of opinion this is one of the most beautiful of the species of recent introduction

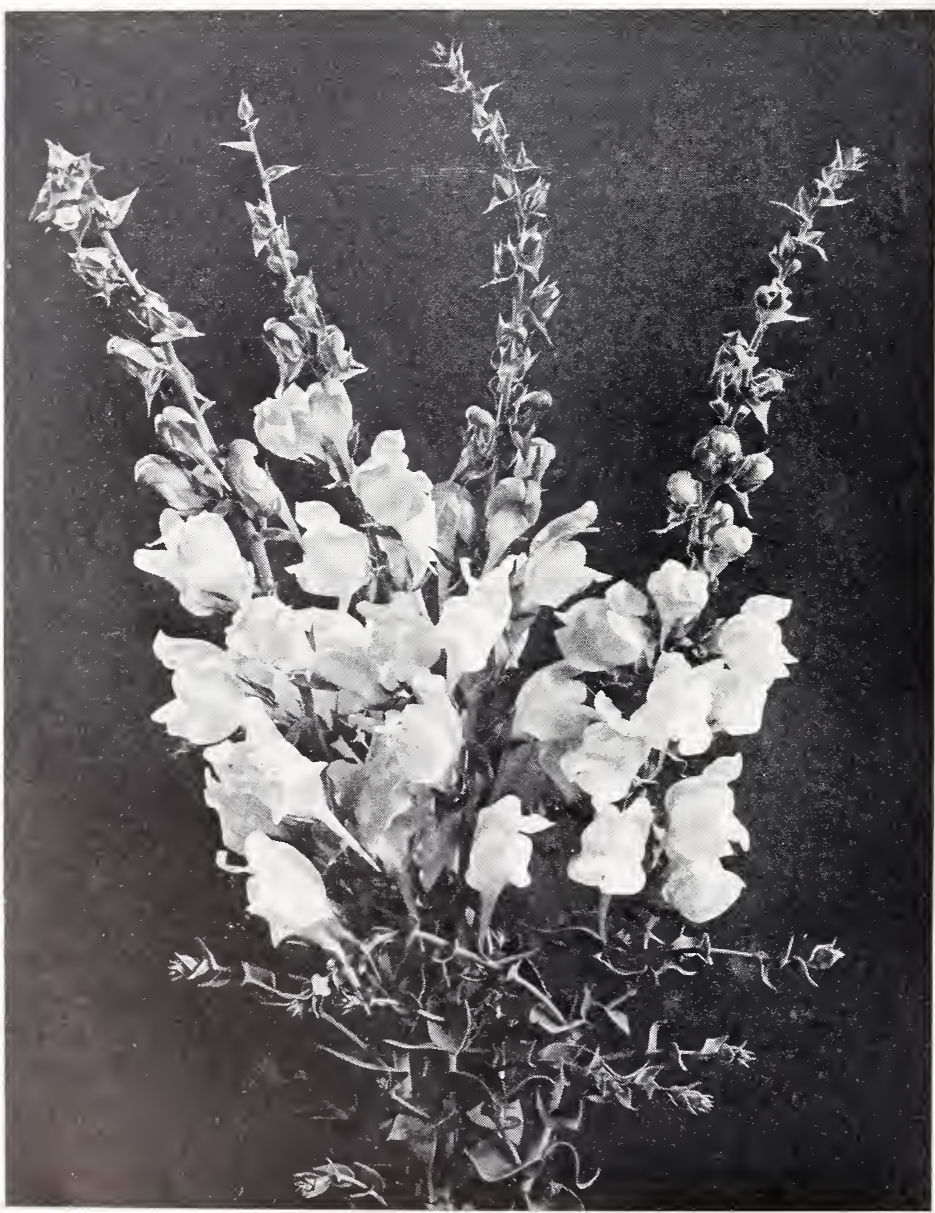

Not a Snapdragon, but a glorious yellow hardy perennial Toad Flax-Linaria Macedonia Speciosa 


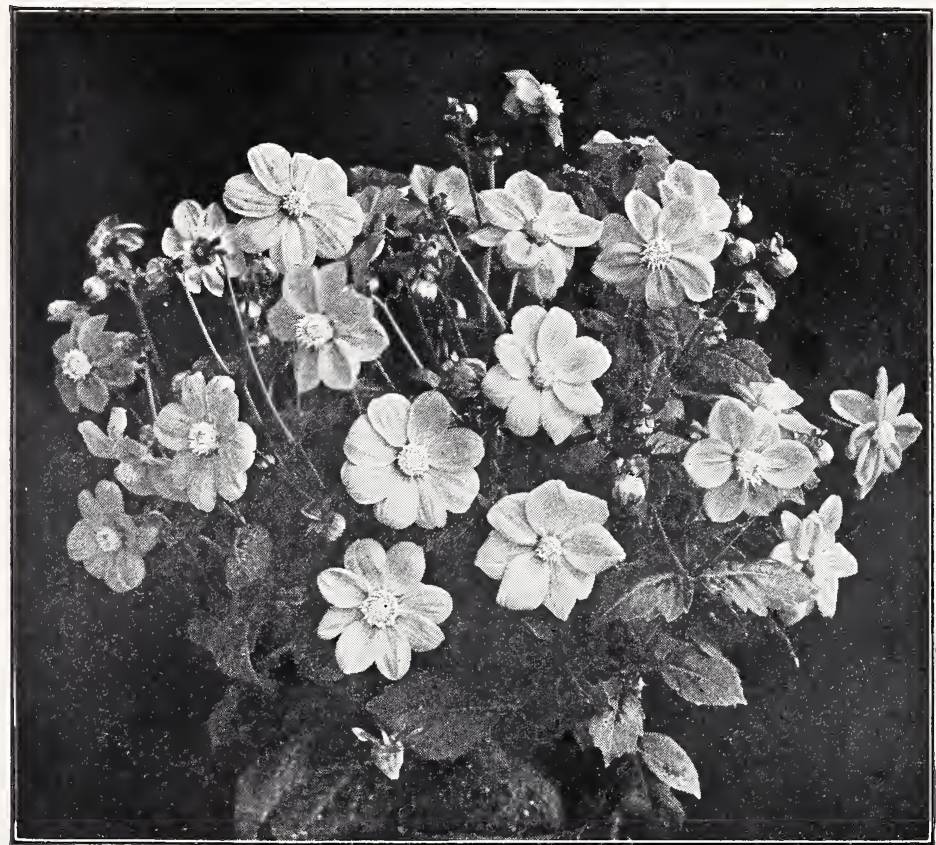

\section{Dahlia "Coltness Hybrids" Improved}

ln offering this special selection of our Coltness Hybrids, we feel confident that our customers will find it a great advance on the type already offered, containing as it does some lovely colors not hitherto found in Dahlias. The coloring of these selected hybrids is very comprehensive, ranging from deep crimson to white, and embracing delicate pinks and roses, as well as yellows and mauves and various shades of scarlets and purples. The habit of the plant is also improved, being dwarfer and more compact, so that we have no doubt that our selection will increase the fame with which this charming class of Dahlia is already regarded. These Dahlias are easily raised from seeds, blooming profusely within 4 to 5 months from seeds, if started in the house in February or early March.

Seeds, $\frac{1}{8}$-oz. $75 \mathrm{c} ; 3$ pkts. for $60 \mathrm{c}$; per pkt.

\section{NEW BEDDING PLANT}

Dahlia Coltness Gem. Brilliant Scarlet Bedding Dahlia, height two feet. Flower easily August to October. Grows anywhere and is fast superseding the once popular geranium. PLANT OUTDOORS FROM END OF MAY. Easily grown from seeds. Per pkt.

\section{LINARIA-(Toad Flax) MACEDONIA SPECIOSA Reselected}

This is a very fine perennial, easily grown from seed, and is undoubtedly the best yellow perennial that can be grown for general use. It is hardy and can be used where medium height is needed in rock garden work. The flowers resemble large golden yellow snapdragons, borne on stems averaging three feet. The foliage is rather attractive and has a silvery medium-sized leaf which extends up the stems at the joint from where the flowers advance. This should be better known and we urge you to grow it as one of the best yellow perennials, and especially now that the size and quality have been improved. 2 pkts. 25 c 


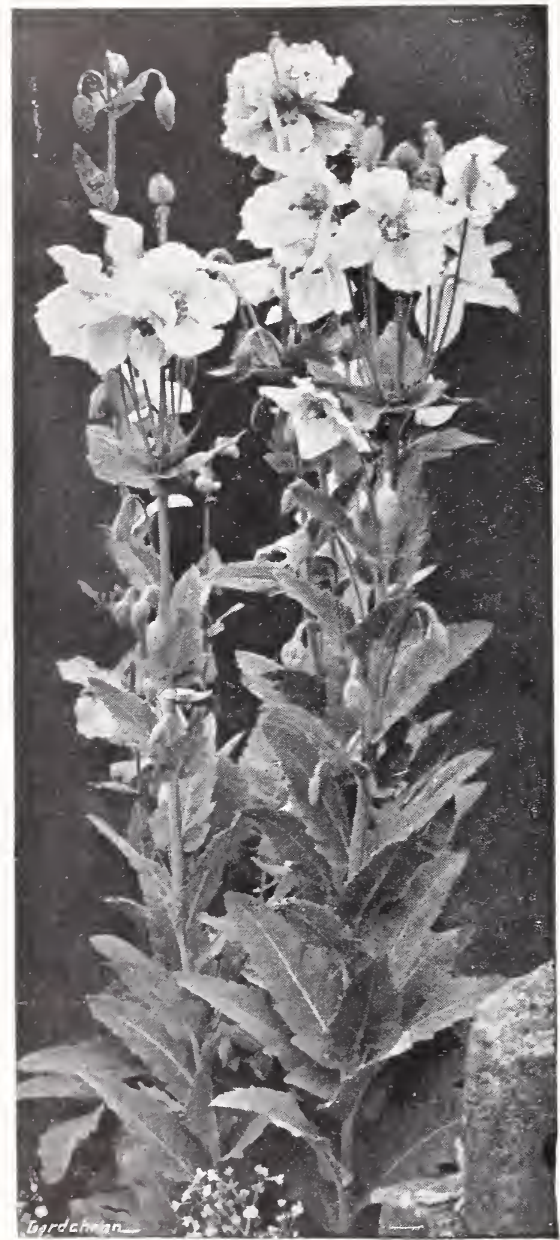

MECONOPSIS BAILEYI

\section{Meconopsis Baileyi}

Meconopsis Baileyi. One of the finest introductions of recent years. This beautiful blue perennial Poppy, brought over from Thibet by Captain Kingdon Ward, throws up from its root-stock half a dozen leafy stems 2 to 3 feet high, well furnished with broad sea-green leaves and bearing freely at their heads large four-petalled blooms of a glorious sky-blue color, the effect of which is enhanced by a central zone of golden-yellow anthers. This superb plant has been accorded by the Royal Horticultural Society a First Class Certificate and an Award of Merit. It is hardy, and should soon become one of the most popular plants in cultivation. Imported seed, per pkt., 50c.

\section{Dianthus Allwoodii Alpinus}

Dianthus Allwoodii Alpinus. The growth is very short, never exceeding 6 inches, and in most cases only 4 inches high, and there is really a delightful range of colors included, chiefly pinks, whites and purple shades, the majority at the moment being laced. Most of them are single flowers, but some are semi-double, and in nearly every variety there is a charming silvery foliage which adds to its charm in the winter. Per pkt., 15c; 2 pkts., 25c. 


\section{List of Choice Hardy Perennial Seeds}

\section{Flower Seeds by Weight}

We carry large stocks of all Flower Seeds and shall be pleased to quote larger amounts of the varieties we list upon application.

\section{ACONITUM-MONK'S HOOD (Family Ranunculaceae)}

A. Fisheri. Height $2 \mathrm{ft}$., deep blue flowers in dense spikes in autumn. 2

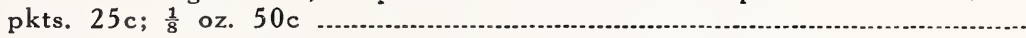

Napellus Praecox. Rare and choice early-flowering variety; deep blue.

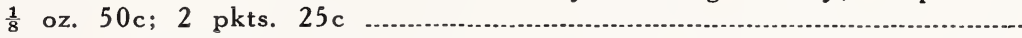

Wilsonii. Light blue or mauve, large and late flowering in handsome spikes; height 5 to $6 \mathrm{ft}$; $\frac{1}{8}$ oz. $40 \mathrm{c}$ The Aconitums are bold, showy plant, growing easily in any soil.

\section{PERENNIAL ALYSSUM, MADWORT (Family: Cruciferae)}

Light soil in the sun for border and rockery.

Citrinum. Charming variety, masses of lemon-yellow flowers, dwarf compact habit, specially good for edging and rockery; $\frac{1}{2} \mathrm{ft}$.; April to June.

Saxatile Compactum. Yellow; April-May; $\frac{1}{2} \mathrm{ft}$; best grown as a hardy biennial and sown annually in July to keep plants neat looking; they bloom the following spring. Lovely in the border with blue Scillas. 3 pkts. for $25 \mathrm{c}$; $\frac{1}{4}$ oz., $40 \mathrm{c}$

Rostratum. Trailing species, yellow flowers in abundance during June and July; $1 \mathrm{ft} .2$ pkts. for $25 \mathrm{c}$.

\section{ANCHUSA, BUGLOSS (Family: Boraginaceae)}

Ordinary soil; lovely blue flowered border plants.

Italica, "Dropmore Variety." $4 \mathrm{ft}$. June to September. Many panicles of lovely Gentian blue flowers; seeds should be sown July to September to bloom the following year; a gem for border effect. $\frac{1}{4}$ oz. $40 \mathrm{c}$;

2 pkts. $25 \mathrm{c}$

Italica "Opal". A perfect gem for border effect. $3 \frac{1}{2} \mathrm{ft}$. June to September; a pale, pleasing shade of blue. 2 pkts. $25 \mathrm{c}$

\section{REGARDING SEEDS sent out by us last spring of ANCHUSA MYOSOTIDIFLORA}

We are sorry to say that this was not the true variety. Not having any plants of this rare Anchusa last year (we now have a large planting of the true variety), we wrote to Holland for our seeds, being assured that the seed was true, but as it turned out this summer when the seedlings bloomed, we found the variety to be AUGUSTIFOLIA, the narrow leaved variety, while the true MYOSITIDIFLORA has round leaves and is of different growth. We are very sorry this happened, and the only thing we can do now is to call attention to this error, and make it good by sending to all our customers who ordered this variety and received the seed in the spring and summer of 1929 and who will write us, a package of the true variety, after the 1930 harvest. We are offering plants of the true Anchusa Myosotidiflora for spring delivery at $50 \mathrm{c}$ each.

\section{ANEMONE-PULSATILLA}

The Pasque Flower. Hardy perennial; desirable early spring flower for the border or rockery. Easily raised from seed. Height, 1 foot. Color, violet. Seed 


\section{ANTIRRHINUM (Snapdragon)}

Half-hardy perennial treated as an annual. One of the finest flowers for cutting; spikes long, gorgeously colored. Seed sown in February or March will bloom from July until frost. May also be sown in open ground in April for blooming in August.

Nanum grandiflorum. Large-flowering, medium height varieties. $2 \frac{1}{2} \mathrm{ft}$. The best type for general use.

"Advance." The flowers are a brilliant orange scarlet with a small yellow spot on the tip of the lower petal. A white throat enhances the resplendence of the coloring and renders the plant, which is of sturdy and compact habit, an excellent subject for summer bedding.

"Red Emperor." This novelty may be described as a rich deep scarlet; one of the finest colors yet produced in Antirrhinums. The habit of the plant is neat and compact and the bloom being produced in great profusion Red Emperor is admirably adapted for bedding in any situation.

"Majestic Sunset." The extra large individual flowers present an exquisite combination of color, being of a bright terra cotta above, shading gradually downwards into a rosy salmon. Viewed from a little distance the tints become merged and the whole coloring transfused into a rich salmon red hue, and thus seen a bed of this splendid new variety seems to reflect the glories of the evening sky, a vertiable sunset shade. We have no doubt as to the future of this grand new class, which compels admiration by its massive beauty and will be of immense value for bold schemes of bedding.

"Majestic Orange King." This novelty, with its sister sort "Sunset," forms the beginning of a new class called "Majestic." There has of late been a tendency among plant hybridizers and selectors to produce Snapdragons with individual blooms of great size, but with little regard to the shape and symmetry of the spike, the individual blooms being too far apart and not always well placed on the stem. No charge of the kind can be brought against this new type, which forms a close spike of elegant shape, the flowers being of extra large size, often 2 inches across at the top. The coloring is an exquisite blend of shades, rich terra cotta above, the lip golden yellow merging to pure deep orange at the base, the general effect when seen in the mass being a brilliant rich orange. The plant is perhaps a little taller and more robust in appearance than the prevailing Nanum type but will be found excellent for bedding, as well as for forming bold groupe in large borders.

Twilight-Judging by the reception given to the varieties already introduced under this heading, we are confident as to the future of this fine new Snapdragon. It has all the eminent characteristics of the MAJESTIC class, great size and perfect form of the individual bloom, combined with ideal symmetry of the spike. The colour is a delicate apricot with old gold centre and salmon shading, the general effect when viewed in the mass being a delicate rosy salmon.

"Dazzler." The plants present a mass of dazzling bright scarlet bloom which seems in the sunshine to burn with a refulgent glow. Being of a very compact and symmetrical habit "Dazzler" makes a magnificent bedder and will, we think, be found to surpass in this respect everything in its class which has yet been introduced.

Any of the above fine novelties, any 3 for $40 \mathrm{c}$. The five beautiful novelties for $80 \mathrm{c}$. Per single pkt.

TALL VARIETIES (Antirrhinum majus)

"Golden King". Improved yellow. 2 pkts. for 25c.................................. 15

"Harmony". Rich terra cotta pink, yellow center. 2 pkts. for 25 c.............. .15

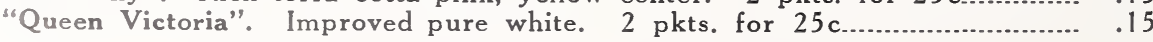

\section{Armeria Gigantea Rosea (Thrift Family)}

An exceedingly fine form of the popular "Sea-Pink" with rosy heads; height $1 \frac{1}{2} \mathrm{ft}$., compact broad foliage. 2 pkts. $25 \mathrm{c}$

A. Bee's Ruby (New). Neat tufts of evergreen foliage; flowers deep rose-pink borne on stout stems; height $2 \mathrm{ft} .2 \mathrm{pkts} .25 \mathrm{c}$ 


\section{AQUILEGIA-COLUMBINE (Family: Ranunculaceae)}

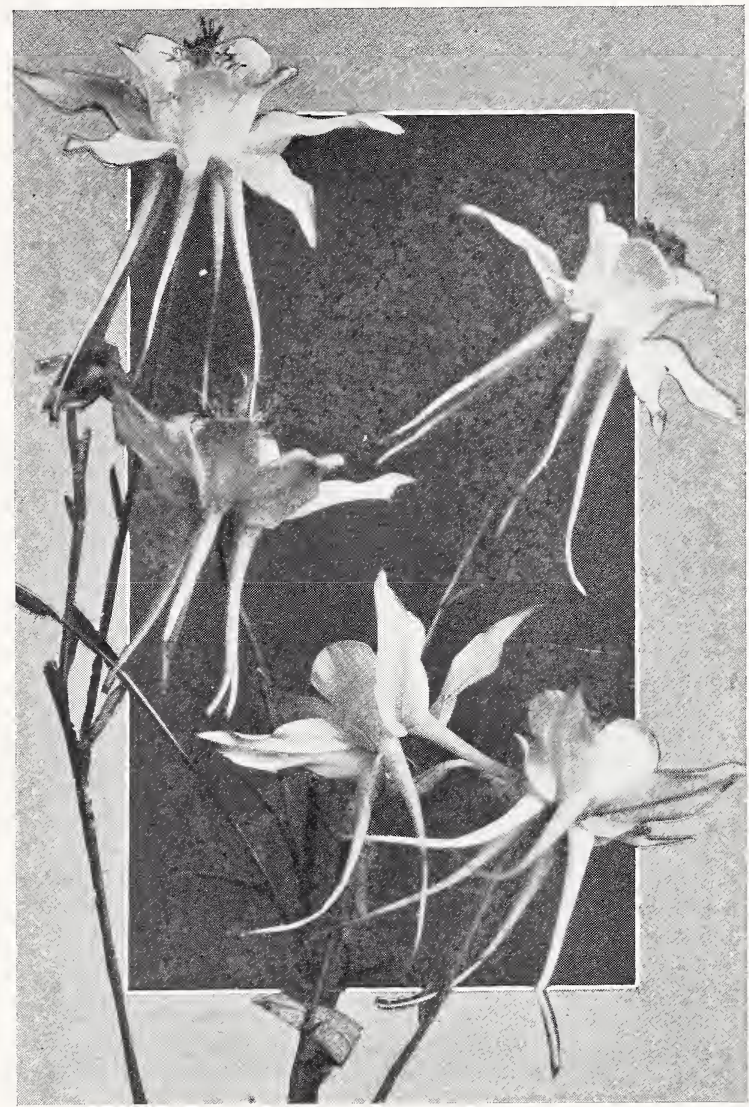

Alpina. A beautiful short-spurred form; clear blue, very rare, a treasure of the Alps; 15 in. 2 pkts. 25c

Mrs. Scott Elliott's Long-spurred Hybrids. Carefully selected for the long spurs and best colors. In shades of pink, blue, lavender, white, yellow, etc., all mixed. 2 for 25 c. $\frac{1}{8}$ oz., 60 c. $\frac{1}{4}$ oz., $\$ 1.00$ Mrs. Scott Elliott's Long-spurred Yellow
Mrs. Scott Elliott's Long-spurred Rosy-Pink and Pinks. Extra fine. $\frac{1}{8}$ oz. $60 \mathrm{c}$

Mrs. Scott Elliott's "Emily Tenney." A lovely lavender.

"Josephine Marsh." A late-flowering, long spurred hybrid, originated in our garden; it begins to bloom when others are commencing to go to seed; the color is a lovely shade of old rose (deep pink) with yellow sepals.. Aquilegia Caerulea. The lovely blue Colorado Rocky Mountain Columbine. Comes true from seed. It is a slow grower in captivity and needs shade and plenty of moisture at the roots, when it will produce the finest, longestspurred flowers you have ever seen. Will not thrive in light, dry, sandy soil. Our seed is absolutely pure and true as we have it collected in the mountains of Colorado. $\frac{1}{8}$ oz. $50 \mathrm{c} ; 2$ pkts. 25c

Pyrenaica. From the Pyrenees Mountains. Strongly all deep blue flowers with yellow stamens; blooms very early before any of the other varieties. $\frac{1}{8}$ oz., $50 \mathrm{c} ; 2$ pkts. $25 \mathrm{c}$ 
Storries Gold Medal Hybrids "Scotland Yet". Brilliant scarlet sepals, petals yellow and other glorious colors; this strain was universally admired in our garden last season. 2 pkts. for $25 \mathrm{c} ; \frac{1}{8}$ oz. $50 \mathrm{c}$

Dobbie's Imperial Hybrids. Unquestionably the finest strain of Aquilegea ever offered. This strain, which we have kept under close observation, is the concentrated work of ten years' selection and re-selection, carried out by Mr. D. Thomson, the Schoolhouse, Duns. It is noteworthy for its very long spurs, fine form, and magnificent range of color. Amongst the "blues" will be found many tints of mauve, lilac, lavender, heliotrope, etc. The "reds" show almost every gradation from the palest pink to bright scarlet. A very special novelty.-(Dobbie's description.) Finest mixed......

\section{CANDYTUFT-R. IBERIS-PERENNIAL CANDYTUFT} (Family: Cruciferae)

Most valuable plants for rockery and the border, giving dense masses of flowers in the early spring.

Gibraltarica. Large white flowers, tinged lilac, very lovely; 12 inches; May to August. 2 for $25 \mathrm{c} . \frac{1}{8}$ oz. $50 \mathrm{c}$.

Sempervirens, Snowflake. Pure white flowers, borne in great profusion, a perfect gem; 2 inches; April to July. 2 for 25 c. $\frac{1}{8}$ oz. $50 \mathrm{c}$..

Carnation. See "Dianthus."

\section{CHEIRANTHUS; WALLFLOWER (Family: Cruciferae)}

Allionii. So-called Siberian Wallflower; orange yellow, continuous flowering; a gem; sweet-scented; 1 foot; April to July and again in the fall if seeds are picked off; may be treated as an annual. sows itself. 2 for $25 \mathrm{c}$.

\section{BIENNIAL CAMPANULA. CANTERBURY BELL}

These certainly are the most showy of all the Campanulas; no garden should be without a few. To succeed with them in cold climates is to sow the seeds in boxes in June in order to get sturdy plants by fall, when they should be transplanted into cold frames, or in a well protected spot outside; the important thing is to keep water and melting snow from the crowns, or they will decay; then in the spring transplant into the border, and you will be rewarded with magnificent spikes of these lovely showy biennials. It is useless to sow the seed late in the summer or in the fall because you would not get large plants for spring transplanting, or at the best you will get only mediocre plants, neither must you sow the seed in the spring, expecting to get blooming sized plants by summer-you won't. In warmer climates the seeds can be sown right outside and the plants later transferred into their permanent places. The important thing is to get large plants by fall to winter over; give them plenty of room in the border, two or three feet, and rich soil.

MEDIUM, Canterbury Bell (This is not the Cup \& Saucer Type)

Single. Blue, white, deep lilac and rosy carmine; in separate colors. 2 pkts.

for $25 \mathrm{c}$; all four colors, $40 \mathrm{c}$; per pkt.

Double. Blue, white, deep lilac, double rosy carmine. In separate colors, 3 for $60 \mathrm{c}$; all 4 for $75 \mathrm{c}$, Per pkt.

\section{CALYCANTHEMA-CUP AND SAUCER TYPE}

We are offering this type in four colors: Blue, white, deep lilac and rosy carmine. Any 2 pkts. for $25 \mathrm{c}$; per pkt.

Canterbury Bells, Pudor's Prize Mixture, comprising all colors of single and double and cup and saucer, unsurpassed. 1/16 oz., $25 \mathrm{c}$. 


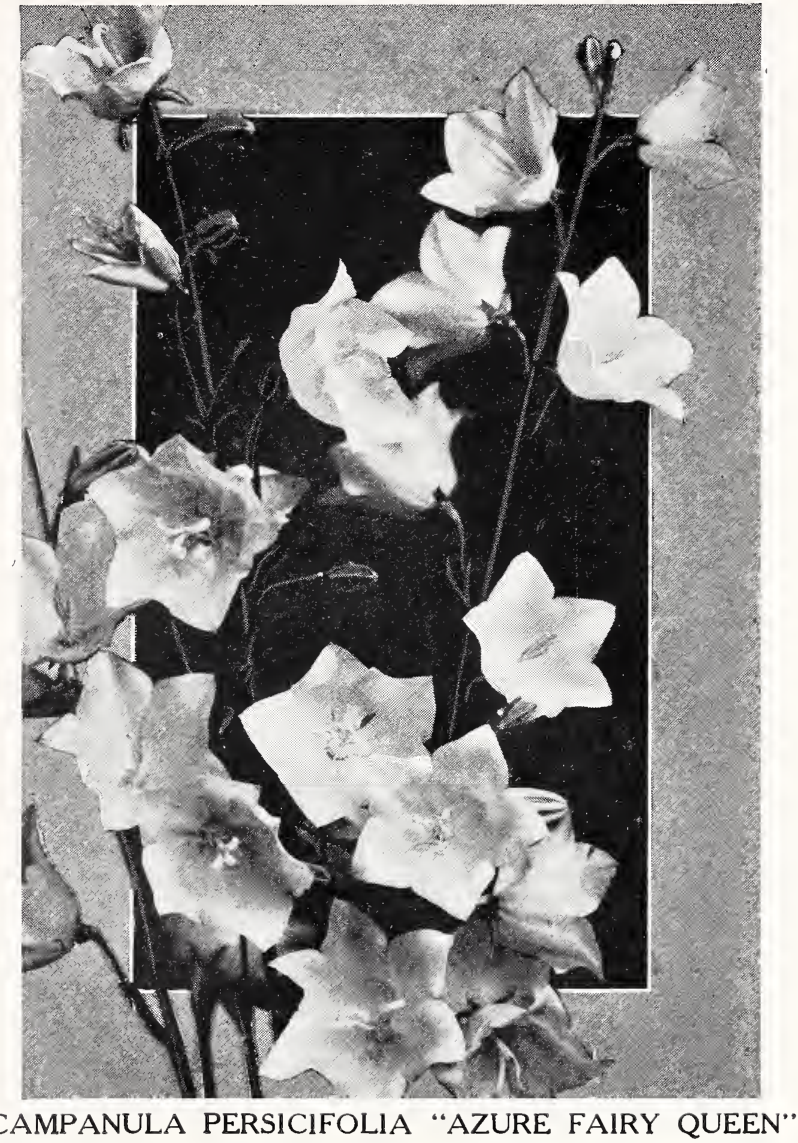

\section{CAMPANULA (The Bell Flowers)}

A sunny position with a moderately rich soil suits them best.

Carpatica. The lovely blue Carpatian Harebell for the rock garden or border.

Height 12 in. 2 pkts. for 25 c

C. Alba. The white form of the above; prices the same.

Persicifolia Grandiflora, Fairy Queen. The lovely peach-leafed Bellflower. Immense, clear, azure-blue bells; height 18 in. to $2 \mathrm{feet;}$ very showy and a most satisfactory cut flower, keeping for days.

Persicifolia Grandiflora Alba. The white form of the above; prices same.

Telham Beauty. (New.) The largest bells of beautiful china blue; height, 2 feet

Rotundifolia. The lovely Harebell of Scotland; pale blue, slender graceful habit; 9 inches

C. Lactiflora. A handsome late flowering Bellflower; one of the best things of late July, growing to a height of over 5 feet in rich soil. Color ranges from nearly pure white to a full purple with many delightful shades between; easily raised from seeds. 2 PKT. 25c, PER PKT.

C. Pyramidalis. The Chimney Bellflower. Fine for the border, 3 feet. Blue 2 pkts. for $25 \mathrm{c}$ 
C. Pyramidalis Alba. The white variety, 2 packs for $25 \mathrm{c}$

C. Pyraversi. Hardy biennial. A New Hybrid with open bell-shaped flowers of lavender-blue with indigo center, borne freely on pyramidal stems ......

C. Raineri. Lovely erect blue flowers, charming alpine plant for the rockery. Rare specimen

C. Persicifolia Flore Pleno "Moerheimii". Double pure white; very fine..........

C. Persicifolia Flore Pleno "Pfitzeri”. Double blue

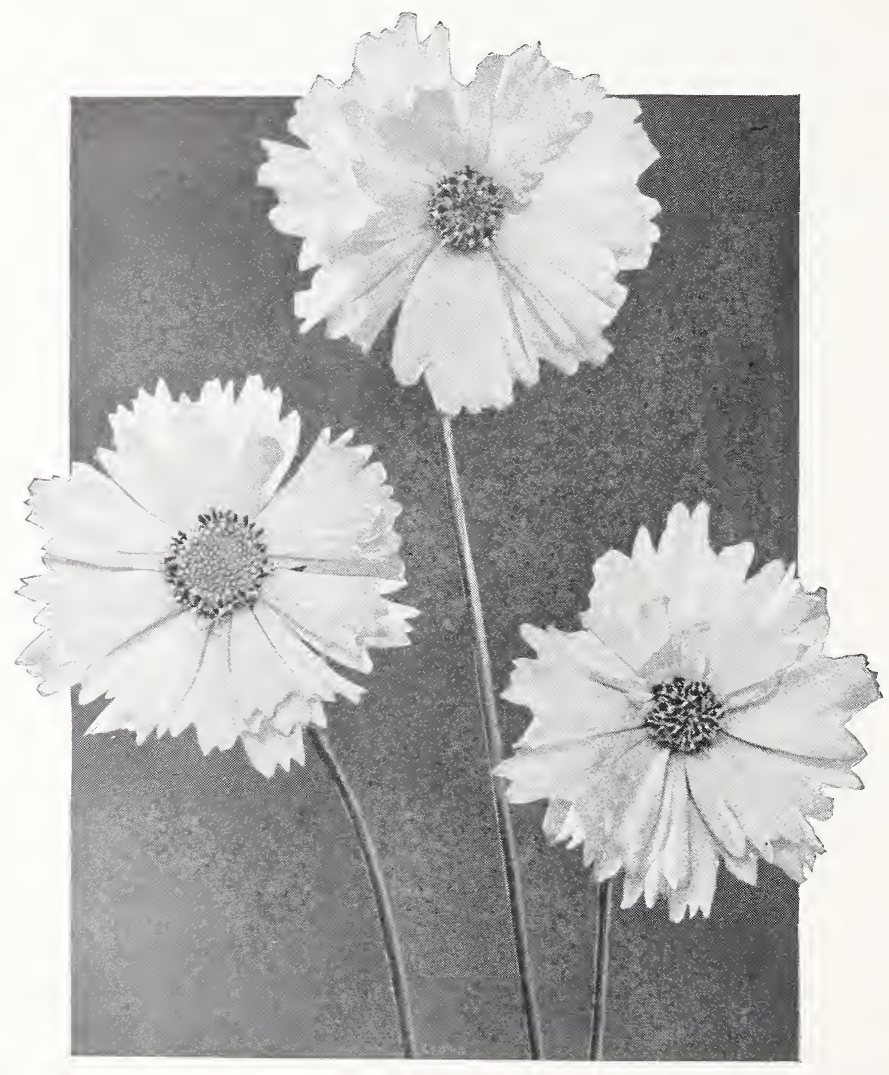

\section{COREOPSIS (Family: Compositae)}

Ordinary soil in the sun.

Pkt.

Lanceolata Flore-Pleno. This is a semidouble form of the well known hardy perennial Coreopsis. From fifty to sixty per cent are semidouble; it is distinctively more valuable than the old single type. Rich golden yellow flowers borne in great profusion the entire summer; a fine popular hardy plant. 2 for 25 c. $\frac{1}{8}$ oz. 35 c.

"A real test of gardening is raising plants from seed. One gardener will get 200 plants, another 10, and another none at all from exactly similar packets of the same seed. The best gardener gets the biggest crop of seedlings. The secret is protection until the plants are large enough and strongenough to shift for themselves." 


\section{DELPHINIUMS}

\section{HARDY PERENNIAL LARKSPUR}

The perennial larkspur has been described as the "finest of all hardy plants," and not without justice, since there is no perennial that is more conspicuous or which possesses a more stately beauty in all its shades of blue, violet, and purple.

The delphinium has achieved its well-earned popularity, not only because of its rich and varied hues, but also because it is without a rival in the border for the ease with which it can be grown and for its ready and generous response to good and efficient cultivation. lts hardy character is easily accounted for by the fact that the progenitors of the plant, which holds so high a place in our esteem to-day, came from the cold steppes of Siberia. Most of the varieties that are grown in modern gardens owe their origin to two old species-elatum and grandiflorum-both natives of Asiatic Russia. These were introduced into this country about 328 years ago.

While its hardiness is an asset, and a very important one, it is essential to remember that the delphinium delights in a deeply-dug and well manured soil. The chief requirements are to give the plants a good start, by so doing we encourage the production of well-developed and stout stems in order to insure a satisfactory supply of healthy foliage and fine spikes of bloom. They also revel in an abundant supply of moisture when growing freely; therefore, water them copiously when they need it, and manure them abundantly.

The plants will accommodate themselves readily in any position which gives ample room for development. This is most essential. They soon form a magnificent group for a sunny corner, a splendid screen for a bare or poorly-clad wall or fence, and a dominating feature for positions at the back or in the centre of a broad herbaceous border.

As the sole occupants of fairly large beds nothing could be finer than massed delphiniums, the imposing effects obtainable being gorgeous. It is well that such beds should be planted by someone who is fairly well acquainted with varieties, and who can so place the plants that the tallest growers occupy more or less central positions in the bed, and thus do not hide the dwarfer plants from view or spoil the balanced effect of the whole bed. Whenever delphiniums may be planted, either in beds of formal character, in irregular clumps or masses, or as intervals in the mixed border, it is all-important that the delphinium shall have elbow room in order that it may obtain its proper quota of air and sunshine. Overcrowding is fatal to its success. There should be at least two feet between each specimen.

\section{GOOD HEALTH FOR THE DELPHINIUM}

Now is the time to forestall three fungoid diseases which sometimes prove the bane of the delphinium grower's life-mildew, black spot and black rot.

For mildew (that grayish-white condition which causes the leaves to shrivel up and the flowers to discolor) dust lightly with lime-sulphur or spray with liquid lime-sulphur, del-bli or qua-sul about once every ten days beginning as soon as the plants are above ground and continuing until the flower buds form. If the above method is used not only will mildew be prevented, but the dreaded black rot or wilt is not likely to appear, especially if the crowns of the plant have received their full share of the spray.

When black spots suddenly appear on the leaves of a previously clean plant we say it has developed the disease called black spot. Another indication of this disease is the forming of a discolored, bluish-black mass at the end of the flower spike which gives it a stunted appearance. Lime-sulphur used as a dust or spray will quickly remedy this fault and in a surprisingly short time the flower spike will come through this black mass in all its beauty.

In cold, heavy soils a black rot fungus sometimes appears on the base of the stems which, if neglected, penetrates to the crown of the plant and causes decay of the root-stock. This malady, which has also been called black rot and crown rot or wilt, has been successfully prevented by the following method: when the plant has been lifted to be transplanted, dust around the crown and top roots with a mixture of four parts lime-sulphur, four parts bordeaux and two parts fine tobacco dust. After setting the plant in the ground dust over the crown with 
powdered charcoal. I have found that plants already started on their way to the black rot graveyard, respond to this treatment after the decayed part has been cut out and wire worm nest removed. On one occasion after this operation was performed I had one piece of root and one shoot, but it repayed me and a healthy plant was the result.

Another good preventative is a 25 per cent solution of semesan, using about a pint of the solution (one ounce to three gallons of water). Spray over the crown as the plants come through in the spring and again two or three times during the growing season if a plant looks in any way unusual. Semesan 1 have found to act as a cure, too, if used in the early stages.

Del-bli is extensively advertised and well recommended. However I am experimenting with this preparation this year and will next season know of its merits as a preventative and as a cure for delphinium ills.

It is my belief, and strongly so, that much trouble is caused by nurserymen who force growth in order to secure large plants the first year by over-manuring. The resulting soft growth is packed air tight and too moist. Decay sets in and by the time the client has received the plants, unless care is taken and the damp decaying material scraped out and treated, the dreaded black rot sets in. Seedling plants must be grown naturally and slowly. Use no manure at any stage. Use bone meal when seeds are planted, bone meal at transplanting time and bone meal and wood ashes during the growing season.

Among insects that crawl on the surface of the soil the most troublesome to delphiniums are cut worms and snails. What disappointment and irritation besets an enthusiast when he finds that the entire center of the crown has been gnawed clean away by some gluttonous snail! Seedling beds, too, suffer from cut worms if no steps are taken to combat them. Bran, powdered alum and soot are recommended to rid the ground of snails, but after careful planting it is worth one's while to find them at night with a flash-light. Poison bran is a sure remedy for cut worms and a plentiful use of lime-sulphur and sometimes soot will keep them in check. Very good ready-mixed remedies are now on the market. -Slater in Horticulture.

\section{SPECIAL NOTICE ABOUT DELPHINIUM SEED}

Delphinium seed is just as good, or almost as good, in the Spring, as it was last August; please, don't get the wrong idea by what you read or hear ;find out for yourself. Some of our seed is not gathered until October 1st, because it does not get ripe before then; now, it would not do to sow seed that late, (except in the greenhouse). Do you think nature would bungle so that this seed, only 6 months old in March, would not germinate? Certainly not. We sow many ounces of seed, as late as the middle of May, and always get a fine stand; all our hundred thousands of seedlings which we grow for sale, are mostly from Spring sown seed; where would we be, if this seed did not germinate well? So with all confidence sow your Delphinium seed in the Spring of the year, if you did not sow it last fall, and don't lose a whole season waiting for the summer seed, for April sown seed will bloom the same year in September and October.

\section{THERE ARE SEEDS THAT NEED SNOW}

Many perennial seeds, particularly seeds of rock plants, won't germinate without the assistance of ice and snow. Perennial larkspur seeds are often a great disappointment as to spring germination. Primroses, with the exception of the polyanthus, often will not germinate if they are sown later than March.

Sow seeds of this class of plants in boxes and set them outdoors to freeze and thaw. Heap snow upon the boxes at every opportunity. Snow seems to awaken the tiny germs in the seeds. If sown in the cold frame do not hesitate to give a covering of snow to melt upon the seed bed. These seeds must have their winter nap in the cold to jump into life.

Delphinium seeds will show the good effect of this outdoor treatment.

Seeds of the irises which are now offered by many firms need this weathering and wintering to make them germinate promptly and freely.-From New York Telegram.

\section{PLEASE DO NOTE!}

As only such seeds as germinate well in our own establishment are supplied to customers, we will not and cannot accept responsibility for failure in the hands of others whose management, lack of equipment or lack of knowledge, may unconsciously be the cause of non-success. 

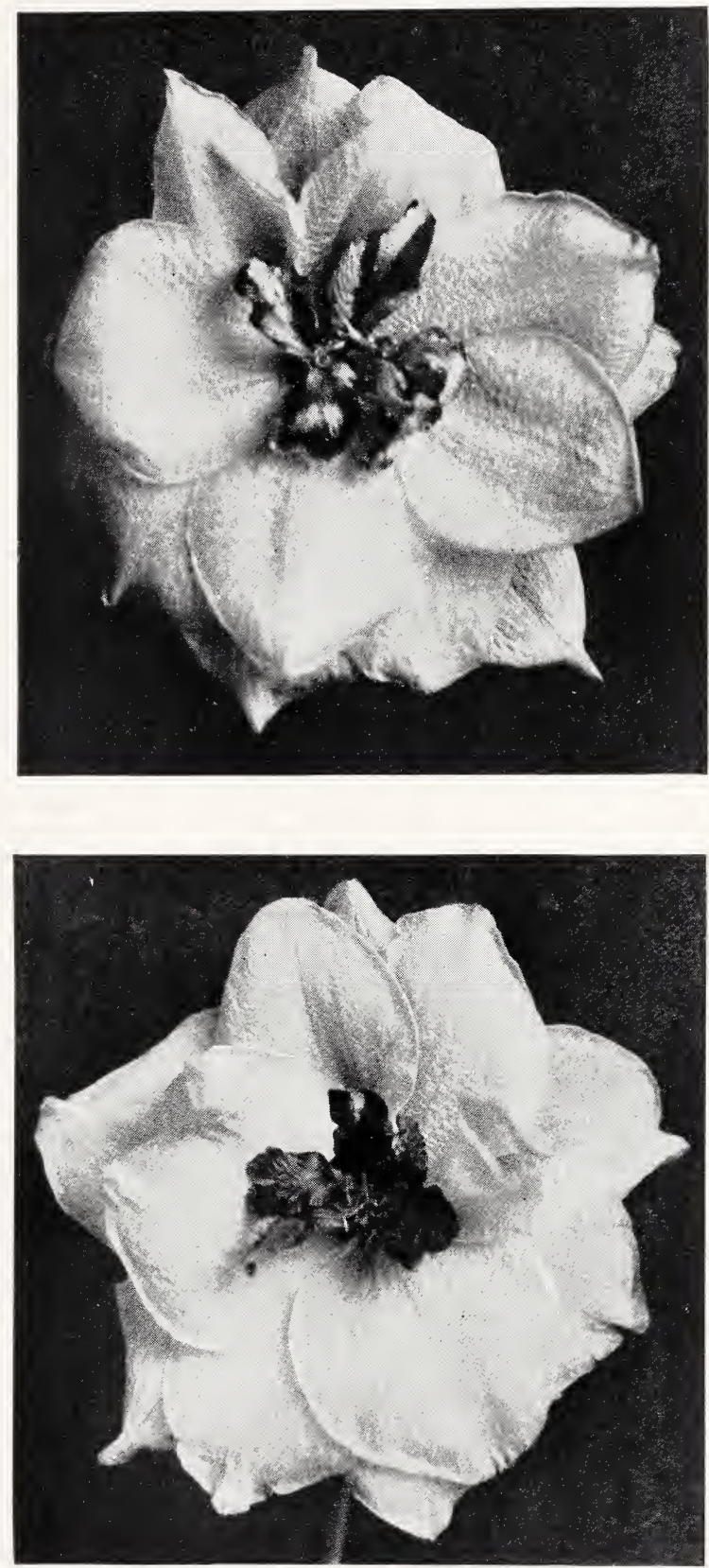

BLOSSOMS FROM PUDOR'S PRIZE WINNER STRAIN Natural Size.

For description, see page 28 . 


\title{
CULTIVATION OF DELPHINIUMS
}

\author{
(From Horticulture, Boston)
}

Various fungus diseases and insect pests are already at work on Delphiniums, making it increasingly difficult to grow these favorite perennials. In some instances where plants have collapsed, the cause probably has been the larvae of the June beetle, which operates at this season and is very difficult to deal with, as it remains under the ground until it emerges as a mature beetle at the end of a three-yearcycle. This pest sometimes gets so bad that an entire renovation of the garden or lawn is necessary. In that case, the best plan is to take out the plants, spade over the ground, and turn in a flock of chickens.

The June beetle is most likely to be abundant in a new garden which has been in turf, but sometimes strays into old gardens from fields or lawns.

It is the blight, though, which is the greatest bane of Delphinium growers. Dry bordeaux mixture dusted over the crowns from the beginning of the season is helpful, but is not a panacea. Several remedies are now on the market. One called Del-Bli has seemed to be reasonably successful. Another, which comes from the West, where it is being warmly praised, is called Qua-sul.

Mrs. Francis King has recommended the following formula: Four pounds of lump lime, one pound of powdered tobacco dust and one gallon of water to slack the lime. When the lime has been slacked as long as it will, add more water, and when boiling has ceased, still more, until there is a total of five gallons. Then add the tobacco dust. Use one quart of this solution to seven quarts of water, and pour a cupful around the roots of each plant. Repeat every ten days if necessary.

lt is not advisable to use fresh manure at any time, but Delphiniums grow well on hand which has been manured for other crops. The best fertilizer is bone meal, which should be applied in the spring or early summer. Wood ashes are also valuable fertilizer for Delphiniums.

lt is especially important to keep the soil around the plants moist. If water cannot be given freely throughout the summer, it is well to mulch the beds with peat moss or some litter which will keep the ground cool and prevent the evaporation of moisture.

Some garden makers like to work a little nitrate of soda into the soil in late June if they have cut the plants back for a second crop. Whether this cutting back should be done or not is a matter about which growers differ. Some believe that the vitality of the plant is weakened to such an extent that it is not likely to winter well to produce more than one crop. Others run the risk, because they want a long succession of flowers, and start new plants every year to take the place of any which may succumb.

Larkspur is readily grown from seed, but this seed must be fresh. It will not germinate well at all when it is over a year old. Seed sown before the first of August will give plants that will flower next year. Delphiniums develop rapidly, and many garden makers who have greenhouses find that by starting the seed indoors early in the season, the plants will flower the same year.

Delphiniums have been improved to a surprising degree, and many of the newer varieties put out by expert breeders are startling in the size and rich coloring of their blooms. method:

Delphinium seed often fail to sprout if they are not entirely fresh, so 1 use this

"Soak Delphinium seed, no matter how old, in a damp rag for four or five days, and then sow them. They will come up within a week after sowing. Do not allow the rag to become dry during the soaking process."

I had some seed bought last year, which would make them approximately two years old, and after soaking them four days, over 90 per cent came up within a week. This is by far the best stand of plants I have had in many years' experimenting, so pass the tip on if it is worthwhile.-S. T. C, North Carolina.

We think it would be better to soak the seeds over night in lukewarm water, dry between blotters and then sow immediately. We never soak our own seeds. 


\section{READ IT TESTINATION OF DELPHINIUM SEEDS}

The first plantings of Delphinium seeds invariably bring report of failures and, usually, seed or soil are blamed. The illustration shows one of half a dozen seed boxes and seems to offer a worth-while method. The secret, if there be one, is merely first care. Delphinium seed must have low, steady temperatures from ten to fifteen days, with constant surface moisture, darkness and apparently company, for best results. The fifteen varieties of seed shown could not have come so evenly save through planting methods. The soil used was leafmold and sand with a little loam to stiffen it. Spraying with a mildew remedy was used to prevent damping off.

Not a single plant perished prior to transplanting. The box was filled within 1 inch of top, wetted thoroughly (lots of drainage was provided) then filled to brim and pressed evenly. The seed was sown in rows and merely pressed in to insure equal depth and covered with sifted leafmold and powdered sphagnum. An empty flat served as a cover when stood on the north side of a wall. The seedlings were up on the eleventh day, the cover being removed on the thirteenth day. The box was brought up to a lath frame on the eighteenth day and fully exposed on the twenty-fifth day.

This method enables one to note first evidence of damping off, permits soil stirring between rows and prompt detection note of slugs or sowbugs, besides permitting equal development of every plant. When sown broadcast in a large bed, none of these advantages exist. A few flats are enough for largest plantings. Pricked out when true leaves first appear, the roots are just beginning to branch and plantlets fall apart easily and never halt in growth. Sown broadcast, one cutworm, or one damping off spot may, before noticed, ruin many plants. Never delay pricking out after true leaves appear.-(Vanderbilt.)

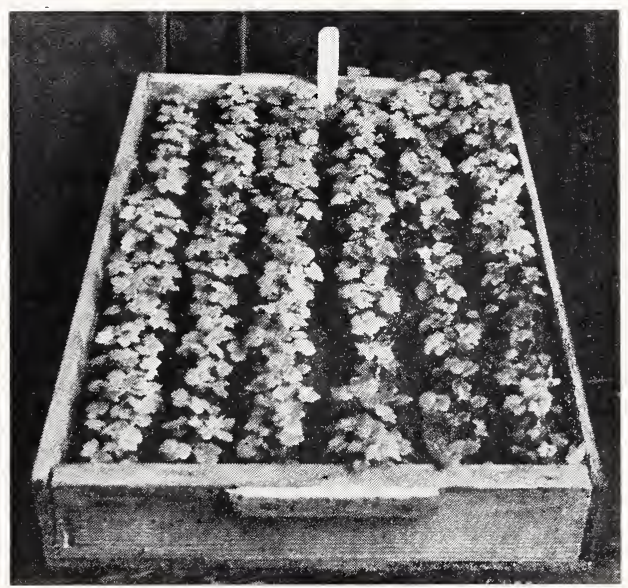

A Flat of Prize Winner "Pedigreed" Delphinium Seedlings, containing over 500 plants, sowed September 1 and photographed October 25 . Seedlings will be planted in the open field in March and will bloom profusely during next September and October. What new surprises will they bring? The flats are wintered in a COLD greenhouse and the tops will freeze down completely. 


\section{DELPHINIUMS AND MANURE \\ By Leon H. Leonian \\ Department of Plant Pathology, West Virginia University, College of Agriculture}

Commenting on the communication of J. W. Greenfield, which appeared in the July number of "Better Flowers," Mr. Barber states that incorporation of manure with soil may have been the cause of failure of Mr. Greenfield's delphiniums. May I offer my own experience with manure on delphiniums? Last year I applied 15 bushels of fresh chicken manure, consisting only of pure droppings, to an area of one-tenth of an acre. The manure was applied between the rows of young but well established plants, and was allowed to remain undisturbed right on the surface of the soil. The soluable matter of the manure was gradually washed into the soil under the action of rains, and the delphiniums began to grow most luxuriously.

Plants blooming for the first time formed flowering spikes of three and sometimes three and a half feet in length, with plants five feet tall. If there was any injurious effect, I failed to see it.

This year 1 tried a similar experiment on another field; to an area not larger than one-fourth of an acre I applied one huge truckful of fresh horse manure, six wagonloads of fresh chicken manure, in addition to fifty pounds of nitrophoska and one hundred pounds of Acadian nitrate of soda. Despite the fact that the soil was sandy and this season has been one of the driest that l have known in this section of the country, my dellphinium plants are doing beautifully; if there has been any ill effect resulting from such heavy applications of manure and concentrated fertilizers, I have not observed it.

It makes a big difference whether manure and fertilizers are applied to the surface of the soil or worked into the dirt.

\section{ARE YOU USING TOO MUCH MANURE?}

We are inclined to think that the increase of disease amongst flowering plants is due to the use of unbalanced manures, especially lack of potash. Plants receiving too much nitrogen produce soft growth, which fall a ready prey to disease organism.

\section{HOW OFTEN DO YOU DIVIDE YOUR DELPHINIUMS?}

One of the causes why some fail with these charming plants is permitting them to go on for years without any attempt being made to divide them, the result being that instead of strong, healthy spikes, and, consequently, fine blooms, the clumps get into a weak condition, owing to a conglomerated mass of thin and spindly shoots. It is only fair to say that a clump carrying five or six spikes is to be preferred to one with three times that number, as with the latter it is almost impossible for the centre spike to get that light and nutriment so necessary if strong flowering spikes are desired. It is therefore best with clumps carrying a large number of shoots to go over them early in the season and cut the weakest away, tying up those that are left to stakes, placing one to each shoot of the tall varieties. If staking is left until late in the season, the stakes are likely to be conspicuous, whereas, done early, the foliage hides the supports, and the risk of damage from rough winds is reduced.

Delphiniums may be raised from seed, or they may be increased by root division, the latter plan being the one oftenest adopted, inasmuch, as a rule, not many plants are needed in a garden. Clumps should be split up in autumn, or early spring, and the ground where it is intended to plant them should be well and deeply dug, some rotted manure being incorporated with the soil. It has to be said of these plants, too, that although the flowering season cannot be said to be a long one, they contribute much beauty to a garden. 


\section{SLUGS AND OTHER VEXATIONS By A. J. Macself (In The British Delphinium Society's Bulletin)}

Delphiniums are subject to a few ills which are capable, if given the chance, of robbing the grower of the fruits of his labours.

Slugs and snails are the most aggravating of the pests that worry these plants. Many and varied are the weapons and the methods of using them in warfare against the legions of these abhorrent enemies, but it matters not what may be used the only chance of success is dependent upon dogged perseverence.

The deadliest of slug destroyers are incapable of exterminating the enemy host at one fell swoop. In almost every case the materials used for destruction of slugs and snails are fully effective only when in a dry state. The mischief is a dry spell keeps the marauders in retreat, but when a heavy shower has rendered our "destroyers" ineffective the slugs sally forth with gluttonous appetites to devour the succulent young growths of our most cherished plants.

Manufacturing chemists have given us many preparations which they claim to be efficient slaughterers of both slugs and snails. Every one of the proprietary articles sold for the purpose is capable of killing slugs which are kept and fed in laboratories for purposes of experiment. They will retain efficiency so long as conditions are such that they come in contact with the slugs in a normally dry state, but very few substances remain effective after a soaking rain, yet that is precisely the time when they are most required. This is no fault of the manufacturers, nor does it spell condemnation of the preparations; it simply indicates the necessity either of making provision for protecting the materials from the effects of rain or of frequent replenishments to ensure the continuous presence of fully active chemicals in the tracks of the pests. The former can only partially be ensured where one's preparations are on a small scale; the latter resolves itself into a question of expense.

Most of the proprietary slug-killers are costly when used ad lib. Naphthalene, which is the active agent in some slug-killers, is potent only for a short period. Even the slight moisture rising from comparatively dry earth accentuates the pace of vaporisation. Any powder containing naphthalene must, in consequence, be replenished at frequent intervals.

Alum will kill the creatures if it is brought into direct contact with them, and so will permanganate of potash. l have used the last-named extensively for Delphiniums, Pyrethrums, Primulas, and hardy Ferns, and I find that by sprinkling the crystals thinly over the soil surface around the plants large numbers of the enemy will be killed in a single night. Even one small crystal is sufficient to end the life of a slug before it travels a yard. With many substances it has been observed that by exudation of slime the miscreant is able to throw off the poison, but the moistening of a crystal of permanganate of potash simply dissolves it until it spreads all over the body, and in a very short time the creature shrivels and dries up.

I have made solutions with a level saltspoonful of crystals in a gallon of water, and by watering stone-heaps, pouring the mixture into crannies between rockery stones and drenching the soil close alongside edging tiles any slugs which may be sheltering in these cool retreats are killed.

One must always bear in mind that successive batches of eggs are constantly hatching out, and even with the most powerful of remedies, second, third and even fourth applications within a reasonable period are advisable.

Mildew is the worst disease which affects the health and destroys the beauty of Delphiniums. Some varieties are highly susceptible to attack; some seem to be almost immune. Weak lime-sulphur solution sprayed on the plants before attack overtakes them is the most reliable preventive, but it must not be used at greater than half fruit-tree strength, or the foliage will be almost as badly discoloured by the remedy as by the disease.

\section{CUTTING DOWN DELPHINIUMS}

Unless required for seed, the old flower spikes should be removed down to the leaves; this will not only conserve the strength of the plants, but assist in retaining the freshness of their foliage over a much longer period. Vigorous plants cut down to within 6 inches of the ground at this date will flower a second time. 


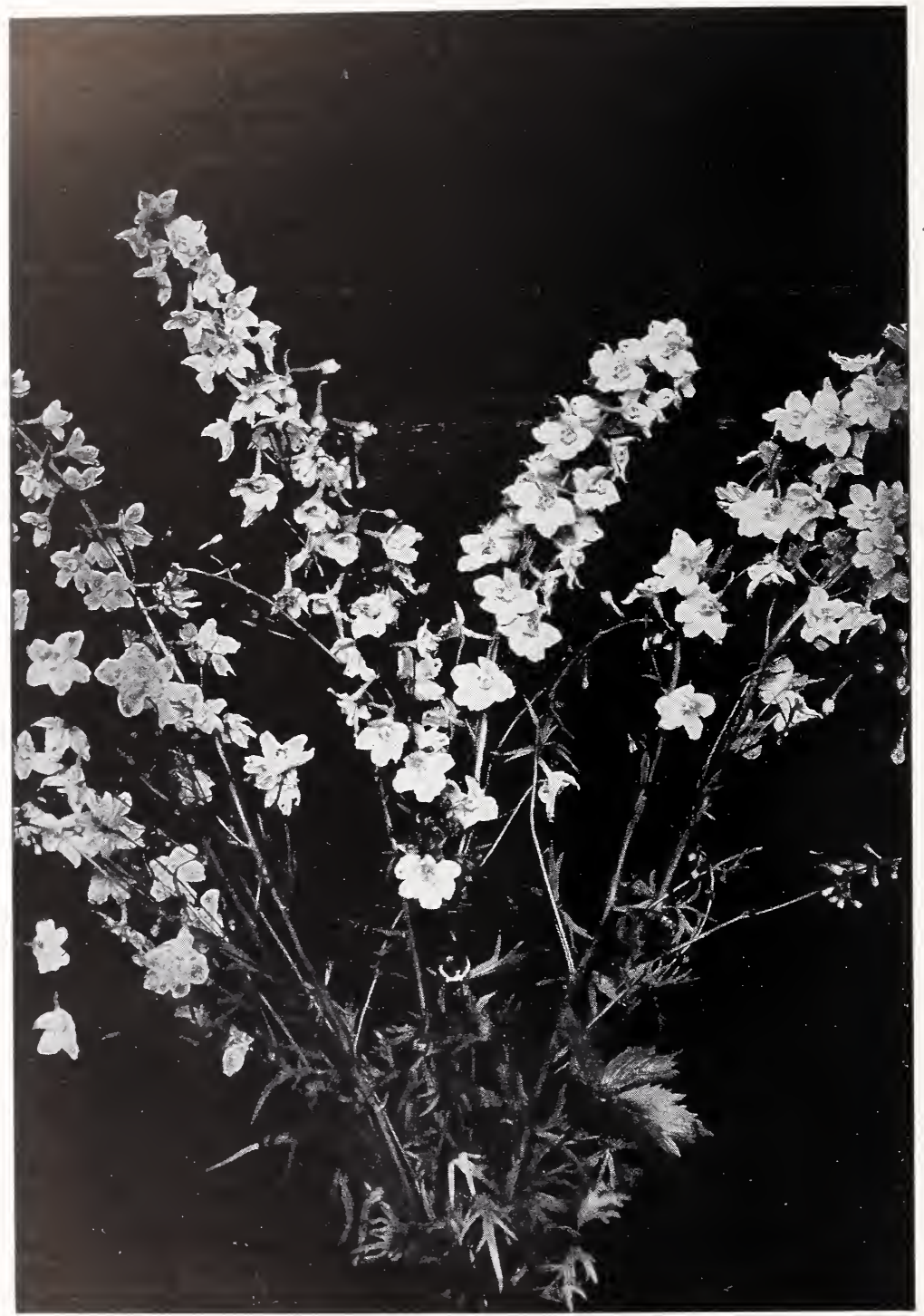

FOR BEAUTY OF ITS EXQUISITE TURQUOISE-BLUE FLOWERS, AND ITS GRACE OF FLOWER STALK, THE "BELLA DONNA" DELPHINIUM STANDS WITHOUT A RIVAL 


\section{NOTES ON GROWING DELPHINIUMS By G. F. Langdon (From The British Delphinium Society's Bulletin)}

Delphiniums repay good cultivation and this implies a thorough preparation of the soil before planting. If of a light, sandy nature, a plentiful supply of rich cow manure is a great help to success, but if of a heavy clay consistency a lighter manure will be better, such as horse manure from stables where plenty of straw is used. Should this not be obtainable, decayed leaves, hop-manure or old mushroom bed manure will be helpful.

The soil should be well dug and if possible to the depth of two or three spits, well incorporating the manure as the work proceeds. It will be an advantage if this operation can be completed a month before planting, to allow the soil to settle.

When planting clumps of Delphiniums in borders that are already occupied with other subjects, it will not be so easy to prepare the places; the same principles, however, should obtain and the soil be well worked and manured before planting.

It is a very debatable matter as to whether it is best to plant in autumn or spring. It depends so much on soil, situation and conditions, and also on which is the most convenient to the grower.

Generally speaking, my advice is to plant early in autumn or wait until spring. This, however, can be modified to suit special conditions and circumstances.

Should the soil be of a light nature and in a well-drained situation, late autumn planting can be practised with impunity, whereas in a wet, heavy soil, it would be fatal, and possibly result in total loss of plants during the cold, wet days of midwinter.

In such a soil, experience teaches one that the first fortnight in September is late enough, and should plants arrive from nurseries at a later date, the safest plan will be to pot them up and winter in cold frames. They can then be planted in the border after they have commenced to grow, in spring.

The Delphinium is perfectly hardy in the sense that it will stand any amount of frost. It is our changeable winter climate that is so often fatal. The wet autumn and winter of 1927-28 was the cause of the loss of many thousands of plants which had they been frozen up all the winter would have come through safely.

There is little doubt that the damage committed by slugs has been the direct cause of many lovers of Delphiniums giving up their culture in despair. That being so, it is well to take all precautions to safeguard them from their depredations.

One of the most efficacious means of protecting them during the winter is to remove all loose soil and small clods of earth from the crown of the plant, and then cover with a little sharp gritty ashes from a furnace to which has been added a little soot. The ashes must be hard and gritty, if soft it will not answer the purpose, as the slug will crawl over it.

The ashes can remain until the young shoots have pushed their way through them in spring. Another method of protection is to surround the plant with a galvanised metal band, first taking care that no slugs are in the crown of the plant.

To trap and kill the slugs is perhaps the best means of protection, and this can be done by placing small portions of bran on the ground and covering with pieces of board or slate, four to six inches square. Slugs are very fond of bran; they will congregate under the pieces of board and can be picked up and destroyed at any time. The traps should of course be examined and cleared of slugs at frequent intervals, and the bran replenished as it disappears. 


\section{PUDOR'S FAMOUS “GLORY OF PUGET SOUND" DELPHINIUM STRAIN}

Pkt.

"Glory of the Valley". A beautiful color combination of light blue and silvery mauve, the sky-blue of the 5 outer petals often suffusing into the mauve of the 7 inner petals, making an exquisite color combination; the bee is small but prominent on account of its snowy whiteness. The variety is exceedingly strong and vigorous, a three-year-old plant producing often 20 or more 7 -foot tall, strong but graceful flower stalks with an unusual large number of lateral spikes or side shoots. $\frac{1}{16}$-oz. $\$ 1.00 ; \frac{1}{8}$-oz. $\$ 1.75$

"The Blue Glory". A glorious flower, indeed it is; a double clear, all deep blue, and no better name could be given it. This variety is giving me some unusual and extra fine seedlings, and two years ago started to producing single and double White Sports. It was from this variety that I produced my fine, new White Glory several years ago. $\frac{1}{16}$-oz., $\$ 1.00 ; \frac{1}{8}$-oz,$\$ 1.75 \ldots$

"The Blue Bird Glory". A new hybrid seedling. Can you imagine in your mind's eye a perfectly shaped large double flower, of an all "blue-bird" blue-if you have seen that heavenly flash of blue along a country road, you will know the glorious effect of that blue in your garden-without a trace of any other blue or any other color; a small white bee; such is "Blue Bird Glory." $\frac{1}{2}$ pkt. 50c; full pkt.

Pudor's Glory of the Sky. Like a clear turquoise summer sky; very large and double without any other trace of color; very inconspicuous bee. $\frac{1}{2} \mathrm{pkt}$. $50 \mathrm{c}$; full pkt.

Pudor's Superb "Private" Mixture. Only seeds from the very finest and newest unnamed seedlings go into this superb mixture, which we sow for our own private use every season to produce finer and better varieties. Customers write: "Your own strain is simply marvelous-lovely beyond compare. 1 like them better than the Wrexhams," etc., etc. Indeed, every season brings new surprises. $\frac{1}{2}$ pkt. $\$ 1.00$; full pkt.

Pudor's Low Priced Glory Mixture. From unnamed, mixed hybrids that have the blood of the "Glory of Puget Sound" in them; you will raise some very beautiful and many double Delphiniums from these seeds. 1-16 oz. $50 \mathrm{c} ; \frac{1}{8}$ oz. $75 \mathrm{c} ; \frac{1}{4}$ oz. $\$ 1.25 ; \frac{1}{2}$ oz. $\$ 2.25 ; 1$ oz. $\$ 4.00$

\section{NEW ENGLISH “NAMED” BELLADONNAS}

Belladonna, Cliveden Beauty. Larger and taller than Belladonna. $\frac{1}{16}-0 z ., 75 \mathrm{c} .25$

Belladonna, Fanny Stormonth. Light azure blue, very large. $\frac{1}{16}$-oz., 75 c ....... .25

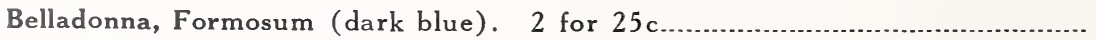

Delphinium Sinense; "Azure Fairy". A real gem for the rock garden; 18 inches high of a lovely clear Cambridge blue; blooms continually if seeds are not formed; universally admired. This variety is best treated as an Annual, and seed sown in spring in the cold frame or in boxes. Blooms in 90 days from seed. 1-16 oz. $35 \mathrm{c}, 2$ pkt. $25 \mathrm{c}$

\section{DELPHINIUM CHINESE or TOM THUMB}

A very dwarf variety of Delphinium bearing a great profusion of flowers in a lovely azure zlue (AZURE FAIRY) and a rich ultramarine blue (BLUE BUTTERFLY). Very fine bedding or rockery plants. Come easily from seed, blooming within 90 days, best treated as an annual, but with us a true perennial. 


\section{ENGLISH NAMED VARIETIES}

As we find many of our garden friends like to grow Delphiniums from named English Delphiniums, we have imported, at great bother and expense, plants of all of the best varieties, and are now in a position to offer you seeds from these named sorts. This includes about a dozen of Mr. Watkins Samuel's own named varieties, originated at Wrexham, England. We do not sell the original plants but seedlings from these only.

\section{GENUINE NAMED ENGLISH DELPHINIUMS FROM OUR GARDEN}

Pkt.

General Sir Douglas Haig. One of the finest Delphiniums yet seen. Deep purple and blue. Award of Merit, Royal Horticultural Society..........
of Delphiniums. A real "King" among Delphiniums. Under favorable conditions it reaches $8 \mathrm{ft}$. in height. A double rich Gentian blue with pium. Very striking white bee...

"Millicent Blackmore." Blackmore \& Langdon, originators. One of the finest double English Garden Varieties. A lovely shade of blue and mauve with large black center.

The Alake. Rich purple, marbled with bright blue, semi-double, large and very fine

Nora Ferguson. This is a queen; a beautiful shade of pale blue blended with soft pink; a good double flower and a noble spike.

Mrs. H. J. Jones. A very robust grower and remarkable free flowering variety; single flowers of a lovely Cambridge-blue shaded with silver; the flowers are elegantly arranged on a strong stem, probably one of the longest spikes; when the flowers have been opened for a few days they are beautifully suffused with pink

Rev. E. Lascelles. A rich, dark double blue with a white centre; makes a

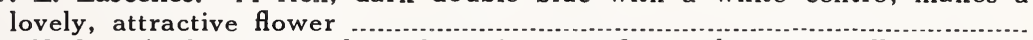

The Shah. A deep, rosy lavender-A magnificent thing; it will give you seedlings that will take your breath away. Award of Merit, Royal H. Soc. Per pkt, (200 seeds)

Seed of any of the above named English variety-except from the Shah$\frac{1}{16}$-oz. (about 800 seeds) $\$ 1.50$.

Blackmore \& Langdon's. Superb Mixture of many of the finest English named varieties, including many new best novelities. You will raise some wonders from this seed mixture. $\frac{1}{8}$-oz., $\$ 2.00$

\section{WATKINS SAMUEL'S ENGLISH WREXHAM STRAIN "HOLLYHOCK" DELPHINIUMS}

\section{A New Race with Spire-like Spikes}

The chief distinguishing features of the "Hollyhock" Delphiniums are (1) the extraordinary length and tapering spirelike shape of the flower spikes; (2) the statuesque beauty of the plants as a whole; (3) the indescribably rich and varied tints; (4) the very remarkable extension of the fowering period, "Queen Mauve" blooms well into August.

\section{OUR OWN NAMED WREXHAMS}

Mr. Watkins Samuel. A glistening, semi-double, all clear light blue with a black bee; the florets set thickly on a perfectly shaped flower stock...

Wrexham Lass. The superb double florets loosely arranged around a perfect spiral stalk; the 5 outside petals a lovely clear blue, the 6 or 7 inside petals soft mauve suffused with blue at their base; bee black, lying flat against the flower petals. We consider this the finest and handsomest variety of the Wrexham strain. Photo, see page opposite.

A Fine Mixture of Splendid Wrexham Hybrids. The seeds coming from many hundred different varieties, all good. $1-16$ oz. $75 \mathrm{c} ; \frac{1}{8}$ oz. $\$ 1.25$. Pkt.

A Superb "Private" Wrexham Mixture. Composed of seeds from superb new seedlings, many better than named varieties, as we raise finer varieties every season. We are using this very same seed for our own private use to produce extra choice varieties. $\frac{1}{2}$-pkt., $\$ 1.00$; full sized pkt ( 200 seeds) 


\title{
MR. WATKINS SAMUEL'S HOLLYHOCK-DELPHINIUMS- HIS OWN NAMED WREXHAMS_SEED FROM ORIGINAL NAMED PLANTS
}

\author{
(We emphasize again: NOT from seedlings of the named varieties.)
}

Queen Mauve. An exceptionally lovely eyeless mauve with a very graceful spike 3 feet long, wide at the base, tapering to the top, with but few side shoots. Inner petals in-curve to such an extent that the eye is practically hidden. A very late flowering variety commencing when the general run of Delphiniums is over. In full bloom in July or August.

Coquette. Violet, shaded a deep blue; a giant over $6 \mathrm{ft}$.

Happy Thought. A medium blue, shaded pansy violet; $5 \mathrm{ft}$.

Monarch of Wales. One of his most famous varieties; gigantic spikes of deep blue and mauve; $6 \mathrm{ft}$.

The Bishop. A rich gentian blue with a white eye; 4 to $5 \mathrm{ft}$. $\frac{1}{2}$ pkt. any variety $\$ 1.00$; full sized pkt.

Any 3 for $\$ 5.00$; $\frac{1}{2}$ packages, Any 3

Seeds from Wrexham "Advancement" seedling plants; claimed to be the finest type of this strain; per pkg. of 200 seeds.

\section{DEAR MR. PUDOR:}

Lexington, Virginia, November 8, 1928.

I am looking forward with the keenest anticipation to the flowering next summer, of the Delphinium seeds I got from you in September.

I have never had seeds germinate as quickly, or as abundantly-or to produce such sturdy little plants as yours.

In my garden 1 specialize in Delphinium (just a small private garden) and I am so delighted to know of your seeds. MRS. B. T.

\section{NO MORE BLACK ROT!}

Mr. O. M. Pudor, Puyallup, Washington.

Cincinnati, Ohio, July 21, 1928.

\section{Dear Sir:}

For several years we have had trouble with what was commonly referred to as "Blight." In one season I lost over five hundred Wrexhams. The spike instead of elongating becomes distorted and thickened into a club-shaped knot about the size of a man's fist. During the summer I was too busy to do anything but guess and during the winter forgot about it until winter before last when upon putting some preserved specimens under a microscope, I was amazed to find an old acquaintance "the Cyclamen Mite." No wonder the fungicides did no good. We then began using "Volck" and nicotine but used too high a concentration of "Volck." This year we have used "Garden Volck" in $3 \%$ solution and a mulch of chopped tobacco; result, no mite. I am mentioning this because 1 am of the opinion that most of the so-called Delphinium Blight in this region is due to this mite. The best remedy for mites I have ever heard of is nicotine and soap, and as "Garden Volck" contains both this probably accounts for the results obtained. We have had some trouble this year with leaf spot due to the wet weather but this is not so serious as it can be eliminated by cutting the affected plants to the ground and sprinkling the ground with a solution of Uspulun or Semesan, $1 / 3-0 z$. to the gallon, $1 \mathrm{qt}$. to $10 \mathrm{sq}$. feet. This is followed by healthy shoots. Next year we will give the treatment as a preventative measure.

The above notes are offered in the hope that they may help others overcome some of their troubles. Also, since using the mercury compounds we have never had any "Black Rot." That reminds me that among our amateur gardeners the injury due to mites is often confused with "Black Rot." 


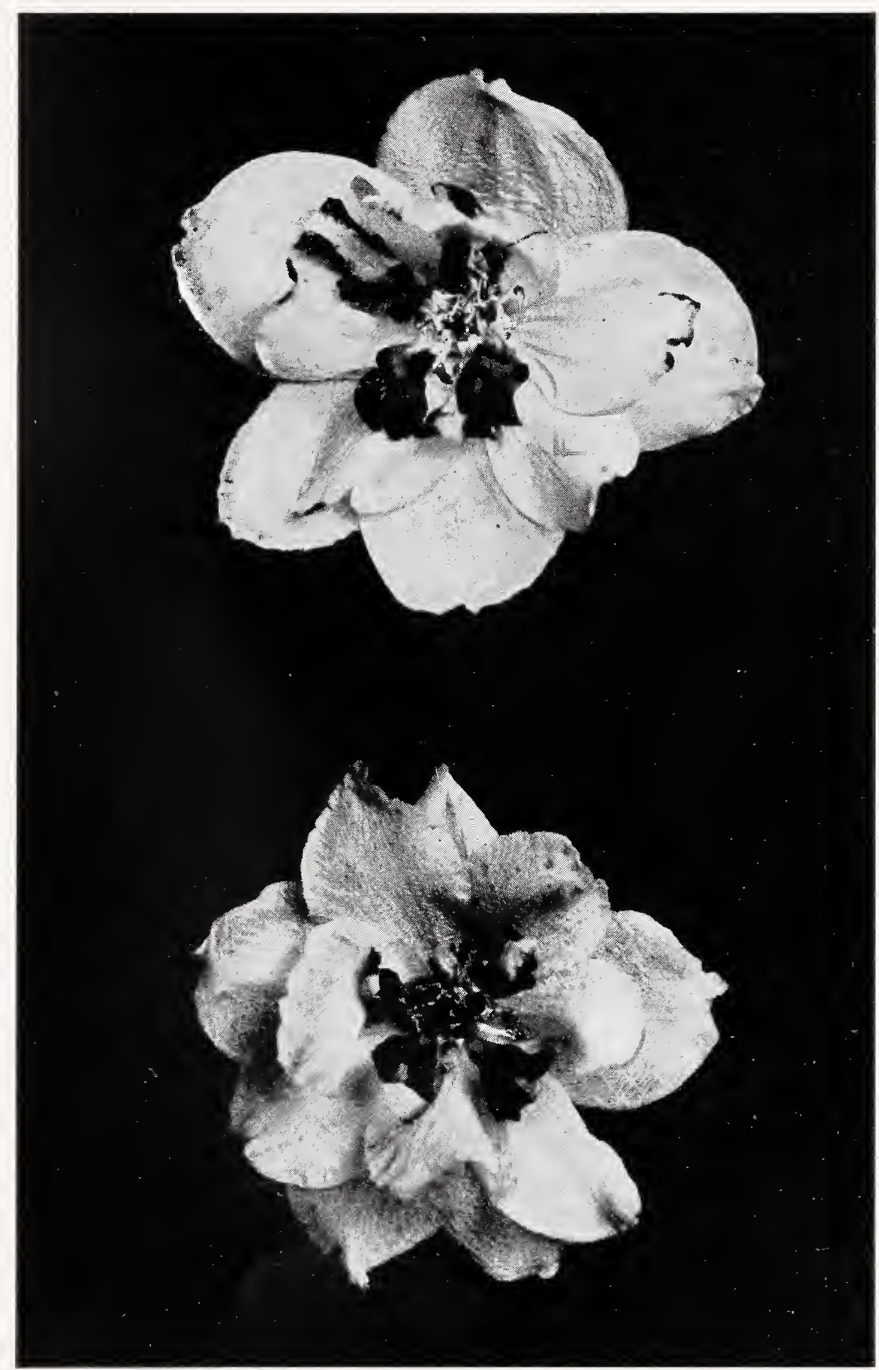

TWO REPRESENTATIVES OF WATKINS SAMUEL'S ENGLISH WREXHAM STRAIN

Originated by O. M. Pudor, at Puyallup, Washington

UPPER: "WREXHAM LASS"

LOWER: "MR. WATKINS SAMUEL"

No Plants for sale, only seeds. 


\section{OURS ARE BLUE RIBBON WINNERS!}

\section{Delphiniums Raised by Our Customers from Our Seeds Win Many Prizes}

Superior, Wisconsin, Sept. 26, 1929.

"Two years ago I bought some Prize Winner Delphinium seed from you and thought you might be interested. l entered in three classes and won three FIRSTS." -M. F. G.

Terre Haute, lndiana, August 26, 1929.

"This last spring a friend gave me a few small plants grown from your seed which was sown in the spring. One of these bloomed and made a wonderful spike which took first prize at the Wabash Valley Gladiolus Society flower show, as the best single spike. My friend and I are both members of the Society, and were both very proud of it."-Mrs. M. T. S.

Richmond, Virginia, August 19, 1929.

'Last September 1 received from you one dozen of your advanced 'Prize Winner' seedlings. Two of these plants gave me a wonderful flower stalk, so double you could not see the bee, the color, a clear blue, overlaid with mauve-truly beautiful.

"l exhibited these at the Henrico Garden Club Show in May, they were the feature of the show."-Mrs. H. W. N.

lowa City, lowa, August 16, 1929.

"Early in the spring of $1928 \mathrm{l}$ bought a package of your "Prize Winner" Delphinium seed. These were planted in a hot bed and transplanted later so that several bloomed that fall. This summer they surely gave me a thrill when they started to bloom. At the time of our flower show in early June only one was in bloom enough to take but 1 won first prize. Prettier ones came out later, and I had two lovely white ones-one especially beautiful with its large single flowers. The Colorado Columbine purchased at the same time was greatly admired in our garden this summer, and I have a bed of 100 Dobbie Hybrid Columbines raised from two packages of seed last fall."-Mrs. E. A. B.

\section{MELROSE GARDENS}

R. P. Liphart, Prop.

3501 Brood Road, Richmond, Va. August 3rd, 1929.

Pudor's lnc.,

Puyallup, Wash.

"l have won first prize on your Delphiniums at every show we exhibited for the last three years."

De Moines, lowa.

"I cannot write you without telling of the wonderful success I have had with my delphiniums which 1 have grown from Pudor Seed. They are truly most extraordinary. Every seed grew and the plants are so much superior to all others that they are not to be compared. Everyone who visits my garden remarks: "What wonderful delphinium. Where did you get them,' and I am always proud to say: 'They are my Pudor's which I grew from seed, two years ago."-E. M. D.

Knoxville, Illinois, July 24, 1929.

"Last fall 1 received one of your seed catalogues and after reading the same, thought you had spread the printer's ink in good shape, but nevertheless I fell to the extent of ordering two packets of you best Delphinium seeds. To say that 1 had the surprise of my life is putting it mild. This is the first time that I purchased flower seeds that they have come up to the catalogue write-up. Yours have surpassed your claims for same and have created a sensation whenever seen for the first time. Have about a hundred plants blooming and no two alike.

"Recently a man from Galesburg, 1ll., saw a few spikes at a friend of mine, and same to the office wanting to buy the whole lot for landscaping a private street in Galesburg. A florist from the same town saw a collection and pronounced four of the spikes MASTERPIECES."-Dr. A. H. H. 

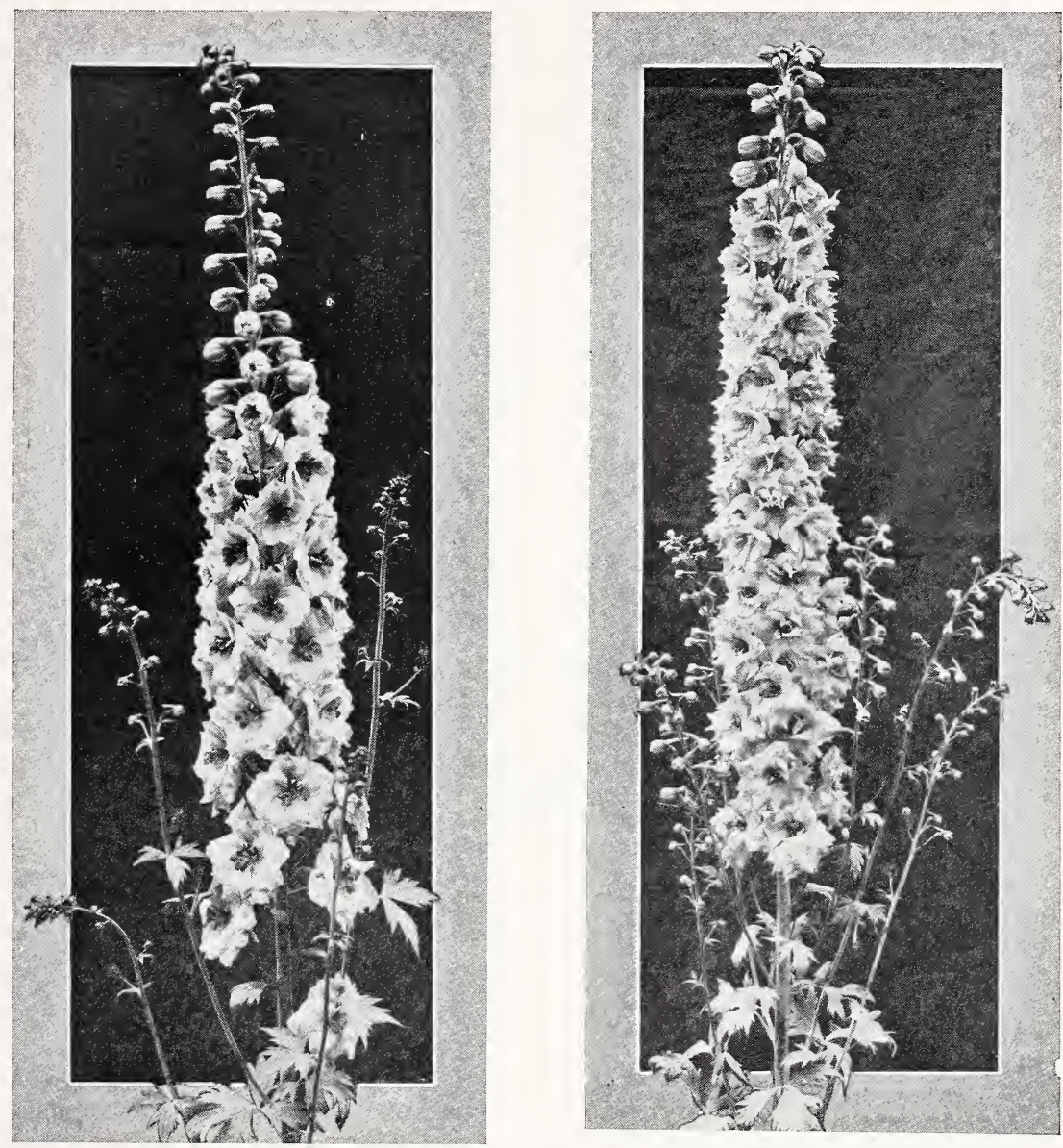

Two Magnificent Seedlings of PUDOR'S PRIZE WINNER STRAIN. You too, can grow such gems, either from our seed or by purchasing small SEEDLINGS.

\section{PUDOR'S NEW PRIZE WINNER STRAIN}

Here we have something entirely new in Delphiniums; marvelous flowers, large and beautiful beyond compare in dark blues and plum shades, and light shades. The individual flowers are nearly always double, often triple and one in a while of full Ranunculus type, often $2 \frac{1}{2}$ " and 3" large. Plants are healthy, strong, vigorous and surprisingly drought resisting, producing marvelous stalks under all weather and soil conditions. We are simply in love with this new strain, and expect to produce some wonders in the next two or three generations. You buying the seed or seedlings can de equally as well.

The stalks are not as heavy and coarse as in the Wrexham strain, bee centers are not too prominent and more pure white than black.

We gave it the name "Prize Winner" strain because we knew they would win many prizes for our customers, and they have, and will continue to do so in the future.

\section{SEED FROM PRIZE WINNING STRAIN}

Only in best mixture some 50 of the choicest selected plans. Per kkt. of 200 seeds, $\$ 2.00$, also put up in $\frac{1}{2}$ pkts. at $\$ 1.00 ; \frac{1}{8}$ oz.. 


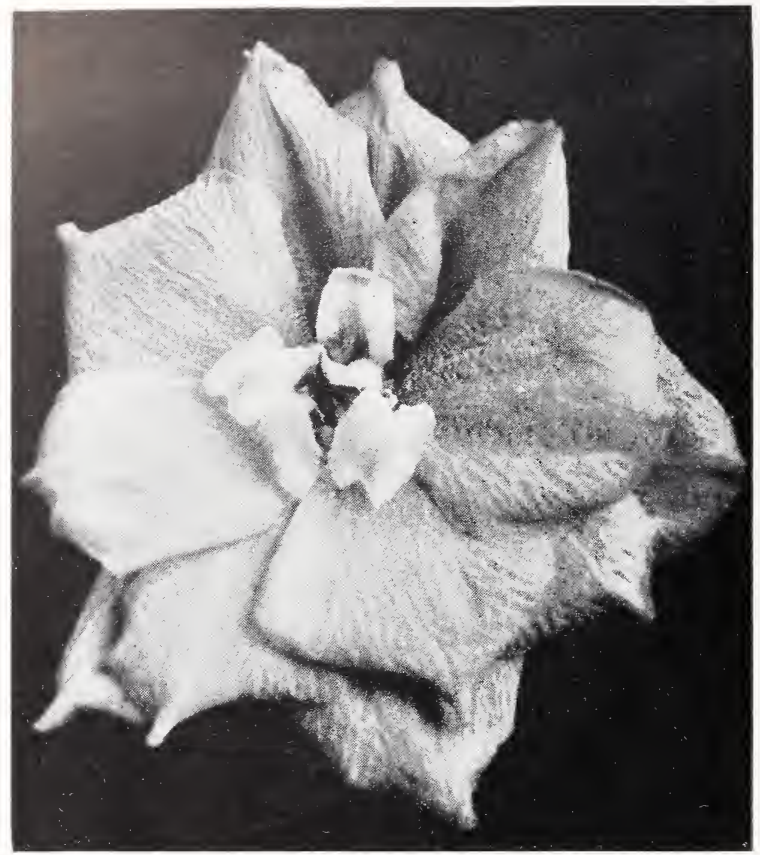

\section{Pudor's "Dream"}

A magnificent 1927 seedling from our PRIZE WINNER strain. Without doubt the handsomest Delphinium ever raised (so far) or grown in our gardens, and we have many gems.

The SIZE? Just put a silver dollar over the above flower, which was photographed from life as the actual size.

The COLOR? The outside petals are a deep clear blue, the inside petals a lovely clear orchid pink, the whole flower being overlaid with a glsitening silver sheen. The Bee is white. CONSTITUTION is most vigorous and robust, the height is up to 7 feet. THE FLOWER STALK is perfect with the large blossom pips beautifully and artistically arranged, not solid and not too thin. Many visitors who saw our four plants (we divided the original plant in the fall of 1928) in bloom this summer, simply stood spellbound before such beauties; one feels like worshipping before a wondrous shrine.

We have a little more seed to offer this spring at $\$ 2.50$ per packet of 100 seeds, this is fifty cents less than what we sold it for last August; next August the new seed crop will again be $\$ 3.00$ per pack of 150 seeds; $\$ 1.50$ for $\frac{1}{2}$ pack. Seeds germinate fairly well; about 75 per cent.

Mr. Pudor:

Akron, Ohio, September 14, 1928.

My delphiniums which I raised from your seed (300 plants) have been wonderful. The Prize Winners are particularly good. They are better than you claim. -M. M. H. 


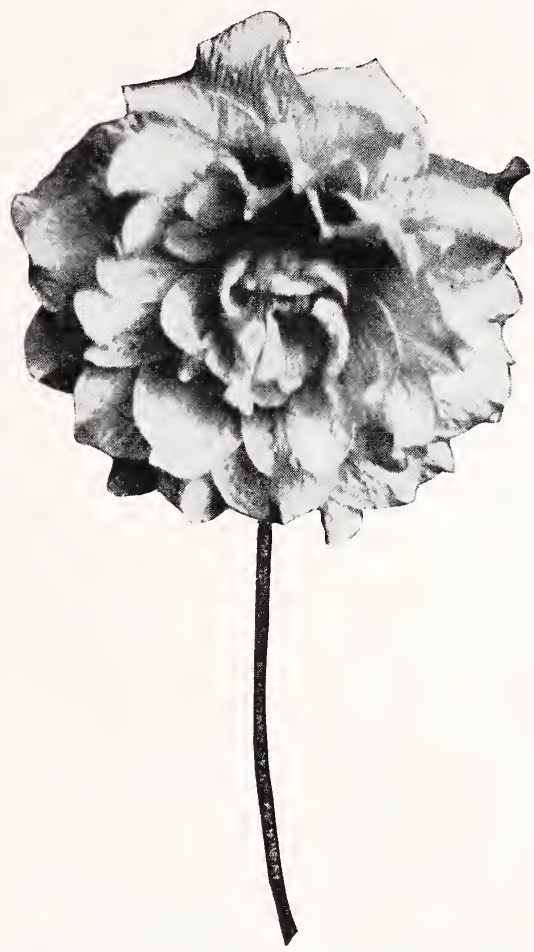

\section{WE ARE CREATING A NEW "PEDIGREED" PRIZE WINNER STRAIN}

The above was the original Sire

Three years ago there appeared among our PRIZE WINNER Delphinium seedlings the above marvellous, so-called "ranunculus flowering type" plant-a beautiful all clear blue. That year it produced about a dozen small seeds from which we raised a dozen or so plants-one being of the same type as the mother plant, the others were, with the exception of two poor plants which we discarded, all very beautiful, perfect, vigorous plants, all with very large double flowers, leaves healthy, beautiful green shade with a slight suggestion of a yellow tinge along the edges.

These first generation plants were duly numbered and seeds from each plant were sown and grown separately; they bloomed the first time during the fall of 1929 and produced wonderful blooms; all were double and some even triple, with only about $10 \%$ single and their vigor and strength was very remarkable for such young seedlings.

Many of the seedlings from one certain numbered parent showed a tendency towards pink; they were all orchid pink without the slightest trace of blue; this is the first time we have ever bred such a color.

To make a long story short, out of all these seedlings, whose parent and grand parent we absolutely know (and remember, the grand sire of all of them was the above pictured rare and unusual plant) we have again selected a few of the best and most promising ones, which have received certain numbers on our books, and these the coming season we shall breed back by hand pollinization to their parent and grand parent, so you will readily see that year by year and step by step we will build up a truly pedigreed strain.

Already in the fall of this coming year, when the fourth generation of these seedlings will bloom, we are looking forward to new and greater things. We selected a few of the best plants for the seed bearers and are offering some of the seeds, 
not very much, to a few of our Delphinium enthusiasts at $\$ 3.00$ per package of 100 seeds. You might get a plant that you wouldn't take $\$ 50$ for. When the few packages are sold that we will spare this spring, all unfilled orders will be suplpied in August from the new seed crop.

Since we will sow this same seed in flats every two or three weeks beginning in February, we will absolutely know how the seeds germinate as time goes on; this also applies to the seeds from our variety "DREAM". We know from past experience that it will be fully $75 \%$ all during the early months of spring, as the seeds were gathered very late in the fall and kept under perfect conditions during the winter. This is certain, should you have bad luck and get only 20 or even 10 plants (however, through no fault of the seeds), you still have made a good bargain to get a few plants from this strain of ours, for only $\$ 3.00$. Many people will get 75 plants. We have sold a few of these seedling plants last fall to a few fortunate customers of ours, who saw them in bloom, as high as $\$ 3.00$ for a small seedling blooming the first time; some of the plants we wouldn't sell for $\$ 50.00$.

\section{PLEASE DO NOTE!}

As only such seeds as germinate well in our own establishment are supplied to customers, we will not and cannot accept responsibility for failure in the hand of others whose management, lack of equipment or lack of knowledge, may unconsciously be the cause of non-success.

\section{DIANTHUS-PINKS}

Pkt.

Barbatus (Sweet William). Finest mixed varieties. 3 pkts. for $25 \mathrm{c}$.

Barbatus (Sweet William) Pink Beauty. A charming new strain, many shades of pink. 3 pkts. for $25 \mathrm{c}$

Barbatus (Sweet William) Scarlet Beauty. Vivid orange or salmon scarlet; very beautiful. 3 pkts. for $25 \mathrm{c}$

Allwoodii Perpetual Border Carnations. Blooming through the entire summer outdoors; flowers are very large and beautiful, mostly single, but deliciously fragrant. 2 pkts. for $25 \mathrm{c}$

After growing these hardy border Carnations for three years, 1 have re-selected

three of the best and most distinct varieties, described and named as follows:

Ophelia. An all clear bright rosy pink with a deeper eye, beautifully shaped round flower, fragrant and unusually large; 2 inches; habit erect, height, 18 in. Every visitor to the garden for the past two years who has seen the plants wanted to buy it. There will probably be some rogues among the seedlings you raise.

Sweet Marie. A large single white with a large crimson center, elegantly fringed petals, very spicy; height, 12 in.

Marjorie. A very attractive orchid pink with a deep crimson eye, fringed petals and very sweetly fragrant.

Dianthus Alpinus. This glorious pink is a native of the Alps and is one of the best pinks for the rock garden; height 3 in. Eacl stem a solitary blossom of lovely rose-crimson. Don't plant in full hot summer sun.

\section{DIGITALIS-FOXGLOVE}

A fine border plant, suited for partially shaded positions. 4 to $5 \mathrm{ft}$.

The Shirley (New). Magnificent strain, enormous flowers from pure white to deepest rose. Mixed. 2 pkts. for $25 \mathrm{c}$

\section{FLAX-PERENNIAL-LINUM}

Sibiricum (Perennial Flax). Dainty, feathery foliage, slender growing hardy perennial, with light blue flowers; $2 \frac{1}{2}$ feet; lovely for the rockery or among other plants. $\frac{1}{8}$ oz. $35 \mathrm{c} ; 2$ pkts. $25 \mathrm{c}$.

Linum Narbonense (New). Very large flowers, graceful habit of deep glistening steel blue; blooms later and longer than the type. A large bed in our nursery was the admiration of every visitor. Height $2 \mathrm{ft} . \frac{1}{8}$ oz. $50 \mathrm{c}$ 


\section{GALEGA-GOAT'S RUE Pea Family}

Showy herbaceous perennials with pretty pinnate leaves, and pea shaped flowers borne in racemens throughout the summer; valuable for screening or bold effects in the border Height, 4 to 5 feet. Flowers are of great value for cutting purposes.

Galega Bi-Color Hartlandi. Beautiful racemens of lilac and white flowers:

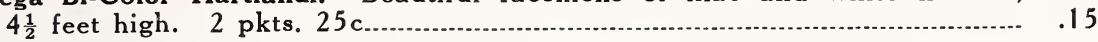

Galega Officinalis. Light blue. 3 pkts. 25c $\ldots$

Galega Nana Roseo-Lilacina Fl. Pl. Dwarf Goat's Rue with double rosy-lilac flowers; excellent for bouquets and cut blooms.

\section{GEUM, AVENS (Family: Rosaceae)}

Pkt.

Lady Stratheden. Rich, golden yellow, double, a great favorite. 2 for $25 \mathrm{c} \ldots \$ 0.15$

Mrs. Bradshaw. 2 feet; large, briliant semi-double orange-scarlet; splendid for cutting. 2 for $25 \mathrm{c}$.

Both Geums are in flower throughout the entire summer.

Fire Opal (New). We imported some plants from England two years ago, though we lost most of them, we will be able to offer seed from this magnificently colored Geum next summer (not this spring).................

Borisii. A very fine hybrid from King Boris' garden in Bulgaria; a beautiful and interesting plant for the rockery; blooms from early spring into late fall, but seeds will not germinate, neither our own nor the seeds we imported from England. This hybrid is probably too highly hybridized. We are offering a few plants, not more than one to a customer, at

\section{GAILLARDIA-BLANKET FLOWER (Family: Compositae)}

These are among the showiest and most effective hardy perennial plants, and should find a place in every hardy border. They thrive in almost any position or soil, require little or no protection and take care of themselves. If sown early they begin flowering in July continuing a mass of bloom until frost; fine for cutting; 2 feet.

Pkt.

Grandiflora, Dazzler (New). Large flowers up to 5 in. across, bright golden yellow with rich maroon red center, fine for cutting. 2 for $25 \mathrm{c}$.

\section{GYPSOPHILA (Baby's Breath)}

Pkt.

Paniculata Double Snow White. One of the most important hardy perennials of recent introduction. The plants grows from 3 to $3 \frac{1}{2}$ feet high, bearing its pretty little double white flowers in much-branched panicles which, when cut, can be used to great advantage with other flowers or by themselves as they retain their beauty for months. lt is also a most desirable addition to the hardy border. Blooms first year if sown early. 3 pkts. for $60 \mathrm{c}$

\section{HELIANTHEMUM-CISTACEAE Rock Rose Family}

If you have any kind of a rockery, you certainly can't do without the lovely Rock Roses, which thrive in rather dry, sandy soil and which are a joy to behold. They are hardy and easily raised from seed.

Vulgare Ruby. Yellow shades, white and deep rose; we offer seeds of these Per Pkt. indispensable rock plants saved from the best named varieties in mixture only. Height 12 inches. 2 pkts. $25 \mathrm{c}$. 


\section{HEUCHERA-CORAL BELLS (Saxifrage Family)}

These charming plants are easily raised from seed; sown in the fall under glass, they will bloom the following season; sown in the spring, they will not bloom until the following year. They make a charming rock plant, grow well in the shade, and will make a very effective border plant in the sun.

Hybrid Mixture. Flowers in rich scarlet, pink and pale rose. Seeds are very Per Pkt.

small and care must be exercised in sowing them $\$ 0.25$

\section{HOLLYHOCKS-ALTHAEA (Family: Malvaceae)}

One of the finest of hardy plants; a clump in any garden gives an effect not attainable with any other plant. For planting among shrubbery or forming a background for other flowers, it is without equal. Seed sown any time before midsummer will produce fine plants for flowering next year.

\section{DOUBLE VARIETIES}

Newport Pink. Awarded a Certificate of Merit by the Royal Horticultural Society of England. It is the finest pure pink, double variety, exquisite in shade, flowers very double. Per $\frac{1}{4}$ oz. $60 \mathrm{c}, 2$ pkts. $25 \mathrm{c}$

Yellow. A fine double, pure yellow. Per $\frac{1}{4}$ oz., 60c; 2 pkts. 25c................

Double Queen of Sheba (New). Beautiful primrose buff with rosy reflection; almost an apricot color.

\section{JAPANESE IRIS SEEDS \\ Spring is a good time to sow them!}

lt takes from 6 to 8 weeks for seeds to germinate in the spring; all will germinate. You can also sow in October as soon as ripe and winter outdoors, with a covering; plants will show up in the spring.

Finest Select Japanese Iris Seeds from our very finest named and unnamed seedlings. Can be planted either fall or spring, and are as easy to grow as peas; wonderfully beautiful varieties may be expected. Bloom the second year from seed. $\frac{1}{8}$-oz., $35 \mathrm{c} ; \frac{1}{4}$-oz., $60 \mathrm{c} ; \frac{1}{2}$-oz., $\$ 1.00$

The new seed crop does not mature here until October 1 st.

\section{ICELAND POPPIES}

Nudicaule Sunbeam. Are you growing this lovely poppy with its exquisite bright-colored flowers of yellow, orange, salmon and white shades? Makes an excellent cut flower subject; when cut in bud lasting for several days in the house. Blooms from May to September. $\frac{1}{16}$-oz., 40c; 3 pkts. for 25 c.. $\$ 0.10$

Tibet. A new lceland poppy from famous Tibet, which may be planted with greater assurance, and which is among the best of the season's novelties. Because of its origin, it has been named Tibet, and the rich orange color of the flowers is different from that found in any other Nudicaule Poppies. One of the most important merits of this new poppy lies in the fact that it blooms late in the fall, when other poppies have passed their prime or have ceased to flower at all. Tibet is at its best in September and October, and is readily grown from seed. 2 pkts. for $25 \mathrm{c}$.

\section{REGAL LILY}

Best sown in spring. Easily grown from seed, $25 \mathrm{c}$ per pkt., $\frac{1}{4}$ oz. $\$ 1, \frac{1}{2}$ oz. $\$ 1.50$, per oz. $\$ 2.50$.

\section{LILIUM REGALE FROM SEED}

The Regal Lily is one of the few popular hardy Lilies which may be rapidly propagated from seed. In some localities it produces seed generously with no extra attention, but in others hand polination is required to induce it to seed at all. Seed 
is produced in pods of from 50 to 250 seeds, the seed being light and flaky, and running from 50,000 to 75,000 to the pound. Seed is sown out of doors in March in drills about $\frac{1}{2}$ inch deep, the rows being from 8 inches to 18 inches apart and with from 10 to 40 seeds to a foot of row. Ordinarily the seed germinates readily and the seedlings begin to appear in from four weeks to six weeks. At the end of the first season's growth the seedling bulbs are from $\frac{5}{8}$-inch to 1 inch in diameter. Many of the largest bloom the second year.

Some commercial growers allow the seedlings to remain in the seed-beds two years, but the beginner will find it a better practice to replant them at the end of the first season. This can be done any time after the top growth matures in the fall and before the bulbs start to make new growth in early spring. The bulbs are set about 3 inches deep and from 3 inches to 6 inches apart in the row.

Seed may also be grown successfully indoors in the winter. If sown then the seedlings should be carried along at a medium temperature until early spring, when they can be transplanted to the open ground. Bulbs should be from 50 per cent. to 100 per cent. larger in the autumn than those from seed planted outside in the spring.

Regal Lilies grow best in a light, sandy, fertile, well-drained soil, but will thrive in any good garden soil. The bulbs are hardy.

\section{PUDOR'S PUGET SOUND LUPINE STRAIN}

These are always the wonder and admiration of the garden visitors during May and June. Colors and shades are simply marvelous and are getting finer every season. Many varieties are becoming sweet-scented like the locust blossoms. Having grown for several years the three best English strains-Harkins, Elliott's and Downers's-we have now evolved out of these three strains, through careful selection and hybridizing, our own private strain, which in many respects surpasses the original strains; rare colors and the most beautiful and rarest color combinations that were never found in the original strains.

It is important that beds should be spaded deep in late fall, as the frost is good for the following season's growth. Well-rotted barnyard compost applied to the soil before spading is good. Leaf mold can be added to the compost. When seed is sown the soil should be made level and worked down firmly. The seed should be covered lightly, not over one-quarter of an inch deep. It is very important to give the young seedlings plenty of moisture. Early spring is the best time to transplant as this will give the benefit of early spring rains. This should be done as soon as the soil is dry enough to be worked. If it is necessary to plant in the fall, do so not later than September 15 to October 1 so they will become well established before winter. Much has been said about the effect of lime on lupines. General opinion has been that all lupines are lime haters. The writer has not found this true; they thrive in England on chalk soil.

Pudor's Pink Wonder. Many visitors to the garden will recollect that wonderful plant-really a bush-with dozens of the most delicate, soft shellpink flower-stalks. We are offering a limited amount of seeds of this....... $\$ 0.50$

You won't get all plants like the mother plant, but you will get some and in addition undoubtedly some other wonderful pinks and other shades.

A Super Pink Mixture. We have made up a carefully selected mixture from all our finest pink shades, except the "Rosy Morn." It should prove a winner

Sweet-Scented Lupin Mixture. Seeds collected only from the sweetest-scented plants in the field; among them are fine pinks, many bi-colors and even some yellows and lovely wisteria shades. These should certainly produce

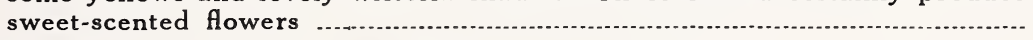

"Blue Beauty." Flowers are a deep blue.

"Purple King". A rich royal purple, same color as Iris "Purple King." ............

L. White Beauty. A pure white form, sometimes a faint flush of delicate pink. 
L. Rosy Morn (Pudor). Large, handsome spikes with deep pink flowers, a wonderful acquisition. Seeds will only partially come true. No seeds of Rosy Morn available until August.

L. Apricot. Very beautiful and rare shades, sometimes almost bronze effects. Seeds will only partially come true to the parent.

L. Yellow Queen. A lovely bright yellow variety of good habit and strong growth. Seeds will only partially come true to the parent.

\section{NEW LUPINES}

Crimson Glow. A beautiful new Pudor seedling. A glowing deep pink that stands out in the distance like a burning sentinel. Better in habit and shape of spike than Rosy Morn; beautifully shaped blossom stalks tapering to a point. No seed available until August..

Sunset. A glorious new Pudor seedling. A color symphony in pink, apricot and gold. Asking a lady what we should name it, she said, "It looks like a glorious Sunset." Handsome, well shaped spikes, tapering to a point like a steeple; slightly fragrant. Very vigorous-we counted up to 40 big spikes on one 3-year-old clump. No plants, only seeds.

Pink Delight. A new seedling of a clear, deep pink color; 24 inches long, tapering slightly, fragrant spikes; a wonderful free bloomer, 25 to 35 spikes on 3 -year-old plants. Seeds..

\section{THE SUNSHINE TREE LUPIN}

This lovely subject was given an Award of Merit by the Royal Horticultural Society of England. The tree Lupines (varieties of Arboreus) are well known, and this is a worthy addition to the family. The plants are more symmetrical than "Snow Queen," and in June and July are covered with flowers borne in graceful racemes. The flowers are yellow, shaded with most charming pink-a sunshine effect. An absolutely hardy shrub, increasing in beauty from year to year. Sown in March and April, bloom the first season. Can be sown in boxes in a frame or in the open ground at any time. 30 seeds.

\section{MECONOPSIS BAILEYI}

Raising Meconopsis from Seed. The seed should be sown in pots or pans, well drained, and filled with light soil. Cold frames are very suitable for the purpose, but it is advisable to cover the pans with a slate or similar object to prevent evaporation until the seeds have germinated, when they must be gradually exposed to light and sunshine. It will be necessary to prick off the seedlings, when large enough, into small pots of sandy and leafy soil, growing them on in a cold frame until June of the following year, when they should be planted out in a partially shaded position in the open. They may be grown in beds and borders in the open, but they are a great deal happier growing under conditions resembling that of a thin woodland, where large decidious trees cast a gentle shade over them; light, however, is of importance, and such trees should be relieved of their lower branches in order that sufficient light may penetrate to the plants. lf you cannot provide such a position, try and find one offering the nearest resemblance. A leafy soil is desirable, such as two parts decayed leaf-mould to two parts of good sandy loam. Some varities prefer a little more sunshine, but the above conditions will be found acceptable to most of this attractive genus.

Given this the plants will luxuriate and become almost as large as cabbages, carrying, in addition to the large central spike of bloom, many large side growths bearing their quota of handsome flowers. Of course, this Poppy, can be successfully grown in cool borders containing a proportion of lime in the soil, but the latter is certainly not essential, and from observation the plant is happiest where lime does not exist. Shelter from wind is desirable, and this is one of the reasons why it does so well in woodland clearings. Like the majority of its genus, position counts for a great deal, and if this is carefully chosen success is certain. IMPORTED SEEDS, PER PKT. 


\section{MECONOPSIS-POPPY-WORTS (Family: Papaveraceae)}

Moist, rich soil in half shady places. A lovely race of poppies from Asia. Pkt. Cambrica (Welsh Poppy). Pretty orange flowers, indigenous; 12 in. 2 pkts.

for $25 \mathrm{c}$.

\section{PAPAVER POPPY}

Gorgeous, stately, beautiful perennials of rich, satiny texture, borne upon three-foot stems. Should be planted and divided in August, as they make a very early fall growth.

Orientale Mrs. Perry. Immense flowers of beautiful soft salmon-pink shades.

Seeds which will give a beautiful range of pink shades, with some crimson

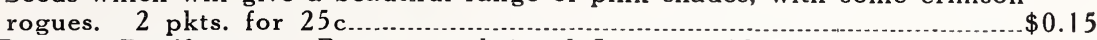

R. Papaver Rupifragum. Pretty, coral-tinted flowers. 12 in $\ldots$

Pyrenaicum. Small and graceful for the rock garden, in lovely shades. 6 in. $\quad .25$

\section{NEW POPPY- “COONARA"}

This wonderful new poppy is one of the very best horticultural introductions of recent years. Similar in habit and appearance to the well-known Iceland Poppy, it is long stemmed and large flowered. The colours are exquisite, embracing all shades of pink, salmon-pink, lemon, cerise pink, tangerine, apricot, old gold, salmon biscuit, salmony saffron, orange scarlet, etc., etc. It is very easy to grow, and certain to please. Exceptionally valuable for indoor decorations. For best results sow at the end of July and transplant the end of September, or plant in early Spring; plants bloom the same season.

Pkt.

Coonara Pink

$\$ 0.25$

\section{PENTSTEMON (Half-Hardy Perennial)}

These plants represent the highest perfection of the many new grand varieties of recent years. The seedlings produce an abundance of pink and scarlet shades with white markings, highly attractive in beds and borders. They should be grown in groups or in beds of at least 12 plants, when they will give a brilliant color effect. Height $2 \mathrm{ft}$.

Hurst's Monarch Strain. Magnificent large-flowered strain, embracing all shades of color.

Pkt.

\section{PHYSALIS (Japanese Lantern)}

Francheti. This wonderfully decorative plant is easy to grow and multiplies rapidly. The fruits are becoming more popular each year for decorative purposes in the early fall and winter. The color of these lantern fruits is orange-vermilion and are ever-lasting after drying. Single plants produce as many as thirty lanterns that sell readily in any flower market. They are beautiful for home decoration, being an ever-lasting. Seeds.

\section{PYRETHRUMS}

The Pyrethrums are deservedly popular plants, the single and double varieties of which contribute much to the beauty of the hardy flower border during the summer months. They flower very profusely, produce a splendid display of glowing colors, the stout, wiry flower stems carrying the flowers well above the elegant, Fern-like foliage, and, besides being attractive in the border, they are extremely useful for furnishing cut flowers for house decoration. The colors range from pure white to delicate pink and rose, through scarlet to the deepest maroon.

Pyrethrums are extremely hardy, and to cultivate them successfully, it is simply necessary to plant in good, rich, loamy soil and to lift and divide every third year. They quickly suffer from drought, and on light soil abundance of organic matter should be incorporated with it when preparing for planting. They are little affected by sun or rain, and maintain a crediitable display when many other occupants of the border have become stained and worn from adverse climatic conditions. There is a large lumber of excellent varieties of both single and double forms.

The seed we sell, and the seedlings we grow, come from the finest double varieties only, and will produce $80 \%$ double flowers-many will bloom single the first year, and then come in double the second year. Seed from the finest double varieties is more costly than from ordinary single. PER PKT. 25c; $\frac{1}{16}$ oz. \$1.25; 1 oz. $\$ 2.00$. 


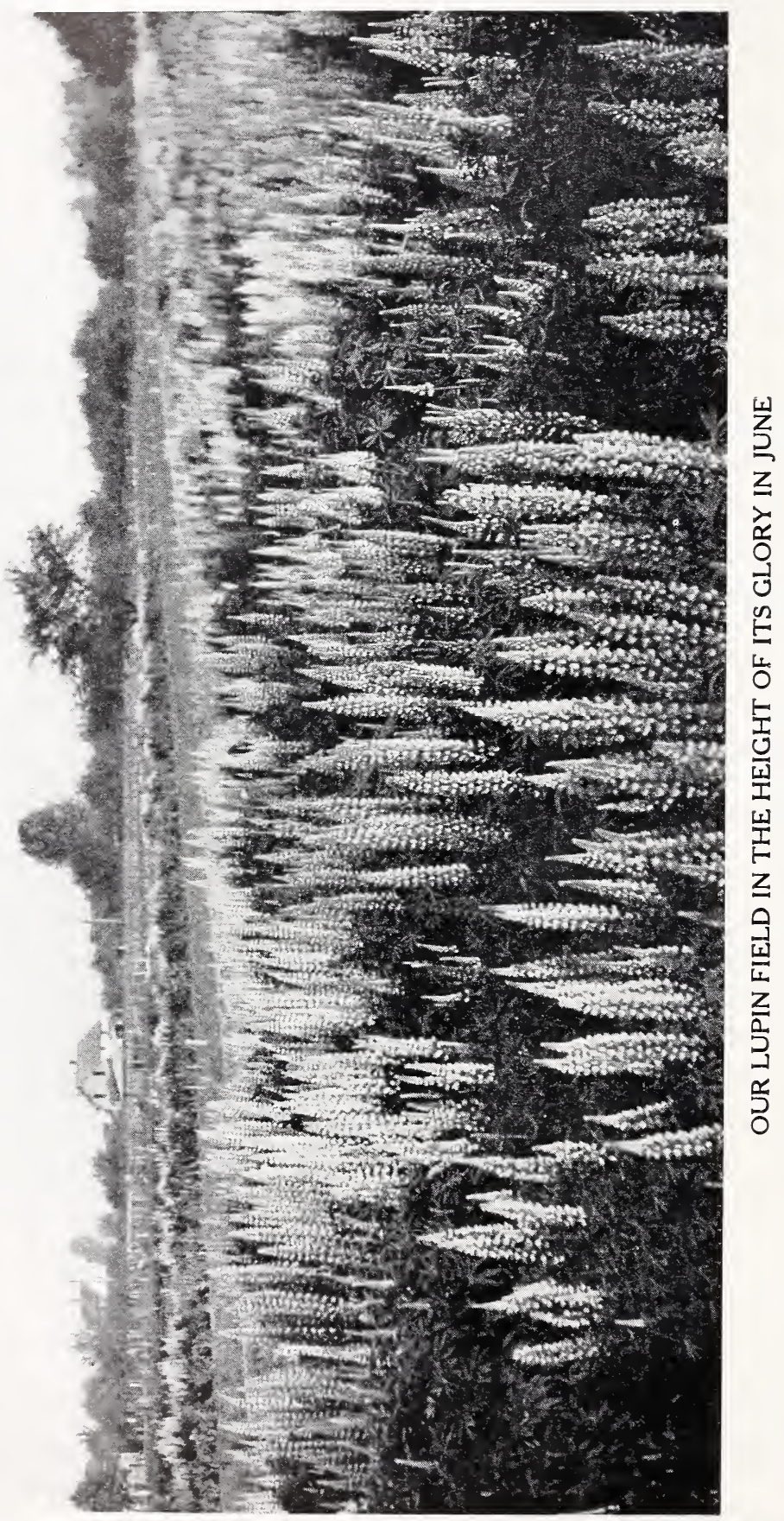




\section{SALVIA-SAGE}

Patens. Tender perennial; $2 \mathrm{ft}$. As blue as blue can be. Suitable for the

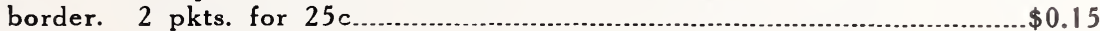

Pratensis. Hardy perennial; two feet deep violet. 3 pkts. for $25 \mathrm{c} \ldots \ldots . . . . . . . . . . .10$

\section{SCABIOSA-PINCUSHION FLOWER (Family: Dipsaceae)}

S. Caucasica. Isaac House's New Hybrids. Hardy perennial; soft lavender blue and lilac shades, prized for cutting; 12 to 18 inches. 5 pkts. $\$ 1 \ldots . . \$ 0.25$

\section{STATICE (Sea Lavender) Pink Baby's Breath}

Splendid hardy perennials, either for the border or rockery, producing all summer panicles of minute lavender flowers, which can be dried and used for winter bouquets. Sow in flats and cover thinly with sand. Keep moist. Pkt.

Latifolia. Lavender-blue flowers. 2 pkts. for $25 \mathrm{c}$. $\$ 0.15$

Secret of success with this seed: sow in flats thinly and cover seeds with thin layer of pure sand, firm down and keep moist.

\section{STOKESIA-CORNFLOWER ASTER (Family: Compositae) Pkt.}

S. Cyanea. Beautiful lavender-blue Corn-flower-like blossoms from early June to October; 18 to 24 inches. 2 for $25 \mathrm{c}$.

\section{THALICTRUM-MEADOW RUE}

Th. Dipterocarpum. Tall growing perennial plants of great beauty, with loose sprays of clear mauve and primrose flowers; most graceful habit; thrives best in rather poor soil in the shade.

\section{THERMOPSIS-PEA FAMILY (Family: Leguminosae) Pkt.}

Caroliniana. 3 to $4 \mathrm{ft}$. June-July. Long spikes of bright yellow flowers. Just the thing for planting among your Delphiniums to bring out the blue. This is a poor germinator, about $50 \%$.

\section{R. VIOLAS—Violet Family}

Treat these same as pansy seed; either sow in late summer, for early spring bloom, or sow in early spring for summer blooming; some varieties bloom all summer through.

Viola Rosy Gem (Rose Queen). An ideal variety for the rock garden. Of compact and dwarf habit, its rosy-pink flowers are very freely produced. $\frac{1}{16}$ oz. $40 \mathrm{c}$.

Pkt.

R. Viola Sutton's Apricot. A charming and unusual apricot-orange color. Comes about $80 \%$ true from seed. A very distinct and beautiful variety. $\frac{1}{16}$ oz. $\$ 1$

Viola Rose Queen. Large lilac to rosy-lilac flowers; a wonderful bloomer, habit not dwarf and compact like Rosy Gem, but forming large upright growing clumps; always greatly admired in our garden. Seeds, 2 pkts. 25c

Viola Haslemere. A beautiful hybrid of a charming shade of lilac-pink in greatest abundance; neat habit; comes quite true from seed. Seed is

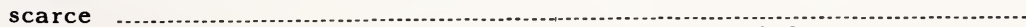

Viola Yellow Gem. A beautiful clear yellow of good habit; very sweetly scented. $\frac{1}{16}$ oz. $40 \mathrm{c} ; 2$ pkts. for $25 \mathrm{c}$.

\section{WAHLENBERGIA-TUFTED HAREBELL (Family Campannulaceae)}

Grandiflora (Platycodon). Blue, large flowered, a fine plant for the rockery. $1 \frac{1}{2} \mathrm{ft} .2 \mathrm{pkts}$. for $25 \mathrm{c}$

Grandiflora Album. Saved from white flowers, some faint blue. 2 pkts. for $25 \mathrm{c}$ 


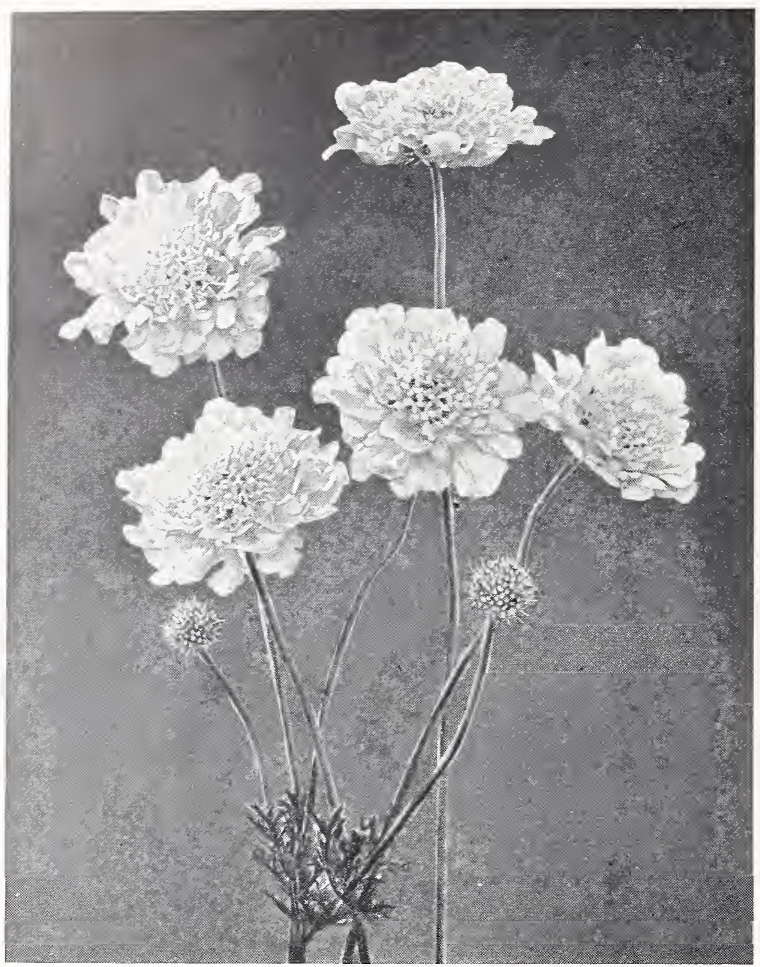

\section{SCABIOSA COLUMBARIA}

This is a South African form of the European Scabiosa and although reminiscent of Causasica, is a distinct type. There is a decided place for this on the perennial list, as well as on the cut-flower list. It can be briefly described as a hardy, low growing perennial with fine, light-green foliage, some of the flowers measuring from two to two and a half inches across with short, compact petals, borne on long, slender but strong stems. WE OFFER THIS IN TWO FAVORITE COLORS-PINK AND LAVENDER. We consider Columbaria a valuable addition to the perennial list, especially the pink shade which is a new color for Perennial Scabiosa. Either color, per pkt. 20c. Not offered in mixture.

\section{SWEET ROCKET-HESPERIS}

The old fashioned Dame's Violet. A hardy perennial, easily raised from seed, blooms the following Spring in May with the Iris and Aquilegia; height 3 to 5 feet; very fragrant. No garden should be without it; a lovely, graceful cut-flower. If you sell cut-flowers on Decoration Day you will find the long, loose sprays a valuable acquisition.

White Sweet Rocket. $\frac{1}{4}$-oz, 25c; 2 pkts. 25c $\$ 0.15$

Pudor's Pink Sweet Rocket. After many years of selecting and re-selecting

We have succeeded in establishing a pure orchid pink variety in place of

the old purple variety. 


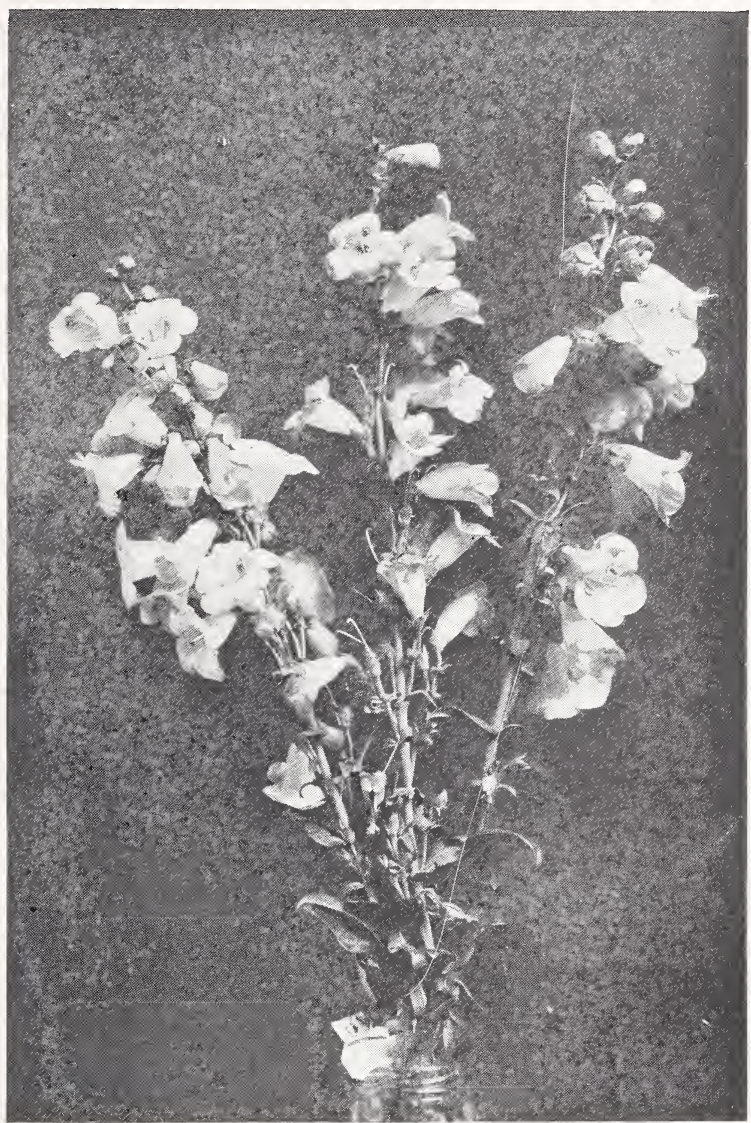

150 Days From Seeds.

The lovely ENGLISH HYBRID PENTSTEMONS-a half-hardy perennial-with their large, many-hued Gloxinia-like flowers. You can have them in flower four months from seeds. In extremely cold climates simply treat them as an annual like Snapdragons, starting the seeds early in boxes in the cold frame or under glass. In half way decent climates where the temperature does not go below zero, treat them like any other hardy perennial, simply mulching them through the winter.

If you don't grow Pentstemons you are missing a very fine and showy perrenial; it comes easy from seeds.

\section{BUILDING A ROCK GARDEN}

Rock gardens are now very popular. Built now one might be one of the striking features in the garden from spring to autumn. It is the later built rock gardens that frequently disappoint. The soil has a chance to settle if the stones are placed in position at once and hollows and cavities as the appear can be filled in and everything packed firm before planting is commenced. This settling of the soil is an important part, for it is not merely a question of pushing stones a little way into the soil, but rather a matter of taking soil to the stones and packing it around them. 
No vacuum should exist beneath the surface of the soil or surface stones. The most usual fault in setting rock is that of so placing the stones that they seem to have no connection with the soil, instead of as the base of the rock garden, barely showing their upper ridges above the earth. The rocks should be placed neither bold upright nor dead level; let them slope in such a way that the soil cannot be washed over them, and each rock must slightly recede from the one below it. The surface of every part should be so arranged that all rain will be absorbed by it. Hence the objection of overhanging faces. Use rock of moderate size rather than a lot of small stones. The latter quickly become hidden, and if stones are not seen here and there the rock garden loses its most striking feature.

The rock garden should be made in full sunshine away from the drip of trees. lt is best to avoid a general level. Therefore a hollow with its shallow banks sloping up easily to the natural floor of grass provides the most suitable location and, dying away to a natural level, will give a quite natural and informal look to the arrangement.

Many are deterred from this, thinking that Alpine plants are difficult to grow and require special soil. For all ordinary purposes any good garden soil will suffice if mingled with leaf soil and sand. This should constitute the upper 9 inches of soil; lower down, anything will do with plenty of stones to assure perfect drainage. Thorough drainage is essential, for although the majority of Alpine plants delight in plenty of water during the growing season they object to water hanging about them for any length of time.

1 do not intend to give a list of plants, but 1 would like to warn would-be cultivators to avoid such plants as Aubrietia, Alyssum, etc., for they spread so quickly and their common qualities militate against them; rather try plants that only thrive under special conditions as regards exposure, drainage, and position.

-H. S. (ln Garden lllustrated).

\section{ROCK FLOWER SEED}

Gathered in my own garden, so you can depend upon its freshness. The sooner after harvesting such seed are planted the better success you will have with its germination.

Aeothionema Pulchellum (Lebanon Candytuft). Prostrate habit $1 / 3 \mathrm{ft}$. Free grower, rose-purple flowers with a long season of bloom. A lovely thing Campanula Rotundifolia. The blue bells of Scotland. 9 inches. Per pkt......... Cheiranthus Allionii. The Siberian Wallfower. A charming dwarf border and rockery plant; 10 to 12 inches, gorgeous orange, very fragrant; blooms the whole time, seedling starting to bloom within 90 days. Price, per pkt., $15 \mathrm{c}, 2$ for..

Per Pkt.

Dianthus Caesius (Pink). The true Cheddar pink; easy to grow and free flowering; 4 inches; clear rose. Per pkt.

Deltoides Superbus. Deep crimson flowers and dark foliage a sheet of brilliant flowers during June and July; wants lots of space; height, 6 inches. Per pkt.

Dianthus Sylvestris. Loose fiowers of beautiful pink over tufts of dark green, wiry leaves. A native of the Swiss Alpine meadows; 9 inches. Per pkt.

Hypericum Polyphyllum. A glorious St. Johns Wort; large, bright yellow flowers; a sheet of yellow during June and July. This St. Johns Wort will never become a nuisance in your rockery. Height 4 in.

inum Perenne Narbonense. Hardy, perennial flax. A beautiful single steel-blue flower; grows anywhere. Don't fail to plant this in your rockery

Papaver-Poppy, Nudicaule, (Iceland-Poppy) Thibet. A glorified lceland poppy; $1 \frac{1}{2} \mathrm{ft}$. Color a brilliant orange. Per pkt.................................. .25 NOTE: The Iceland poppies may be treated as annuals, sowing the seeds under glass early in the Spring, but should be sown in the open in July or August for Spring flowering.

Papaver-Poppy, Rupifragum. Pretty, corral-tinted flowers on long stems; 12 in. Per pkt. ............ Tufts of grass-

Wahlenbergia (syn. Edaianthus) Tenuifolia. From Dalmatia. Tufts of grass-
like leaves from which radiate clusters of deep violet bells. Per pkt.... 


\section{HINTS ON SOWING FLOWER SEEDS}

When sowing seeds bear in mind the fact that every fertile seed contains a living plant in embryo. The germ of life is there in a state of suspended animation and only awaits favorable conditions to quicken and develop. Water, heat and air are the all-important factors, and a happy combination of these must be the object of all preparations.

\section{WATER}

As a general rule, a seed requires to take up a quantity of water equal to its own bulk to enable the germinating processes to commence. After these have once started, germination must go on, and growth continue, or the embryo will perish.

\section{TEMPERATURE}

Experiments have proved that seeds of hardy plants give the best percentage of germination if sown in a temperature of $45 \mathrm{deg}$. to $50 \mathrm{deg}$. Half-hardy subjects should be given $10 \mathrm{deg}$. more; while Cucumbers, Melons, Bananas, and the like, which revel under tropical conditions, should be afforded a seed bed temperature of $70 \mathrm{deg}$. to $75 \mathrm{deg}$.

\section{AIR}

Seeds breathe, giving off during the germinating processes carbon dioxide, and unless this can readily escape, germination is materially hindered, hence the advisability of using an open sandy compost that air can readily penetrate.

\section{SEED SOWING UNDER GLASS}

Seeds of any type sown under glass in pots or boxes should be sown very thinly, and be just lightly pressed into the soil with the aid of a piece of board. The soil should have been previously moistened and allowed to drain, and after sowing cover the seed with three times its own diameter of fine sandy soil. By this method the seed is enclosed in a moist bed, from which loss of water by evaporation must be checked by covering the pots, etc., with sheets of glass, and shading from direct sunshine with paper until the seedlings appear, as the soil must on no account be allowed to become dry after sowing. If possible avoid any further watering until the seed has germinated, but should it appear necessary water is best applied by standing the pot or pan in water up to the rim.

\section{SEED SOWING OUT OF DOORS}

Outdoor sowings are less under control, but the careful cultivator will usually be able to get a satisfactory seed bed. This is of the utmost importance, as much good seed is ruined by being sown when the soil is in an unsuitable condition. Good results can never be obtained by sowing in a pasty soil, the land should work freely without "balling," a condition that can often be obtained early in the season by lightly forking over and leaving to dry for a few hours in the sun and wind before attempting to rake down.

\section{SOWING HARDY ANNUALS}

Seeds of Hardy Annuals can be sown direct into the position in which the plants are to bloom; making both spring and autumn sowings, the best months being March and April-September and October respectively for most types. Prepare the positions thoroughly, sow the seed very thinly and cover with fine sandy soil. Many species, including such favorites as Mignonette, Clarkia, Godetia, Nigella, Schizanthus and many others, transplant readily, and an earlier supply of bloom may be obtained by sowing these subjects in boxes in gentle heat during early March, hardening the plants prior to transplanting to their flowering positions during April. The first mentioned is popularly supposed to be a difficult subject to transplant, but this will not be found to be the case if transplanting is firmly done when the soil is in a fairly moist condition; the plants should not be watered in, but may be freshened by spraying with a syringe, or fine rosed can ,should the weather prove dry and sunny. 


\section{SOWING HALF-HARDY ANNUALS}

Such as Asters, Phlox Drummondii, Salpiglossis, etc., should be sown in boxes as pots on a mild-hot-bed during first or second weeks in April, and grown on steadily during the six or eight weeks that must elapse before it is safe to put them into their flowering quarters. The more tender types usually grown for greenhouse decoration, as for instance, the Thunbegias, Celosias, Torenias, etc., should be sown in good time, say April at the latest, or the season will be far spent before they are in bloom.

\section{HARDY BIENNIALS}

Should be sown at an earlier date than is usually the case; much better plants can then be obtained and the wealth of bloom these will give in the spring will amply repay. A good general rule to adopt, and one that will provide a useful timely reminder, is to make a point of sowing seeds of Hardy Biennial plants for the following year's supply at the time the current year's plants are in full bloom.

\section{HARDY PERENNIALS}

Seeds of these should be sown during spring and early summer, and where the convenience exists it is a good plant to sow in pots or boxes in a cold frame, transplanting when large enough to handle into nursery beds until the autumn. Otherwise, the seed may be sown in the open ground, observing the precautions already advised as to conditions of soil, etc. Shading is important and the seed beds should be protected from full sun until the seedlings are well established.

\section{THE USE OF COLD FRAMES}

Cold frames are easier to construct than hot beds, and much simpler to handle. The maragement of hot beds requires no little skill. They will be used on large estates where there are professional gardeners, as a matter of course, but the average amateur will obtain much better results from cold frames. The difference between hot beds and cold frames is that the former are heated, usually by means of a thick layer of fresh manure under the surface soil, while no heat is used in cold frames except that which is received from the sun. Cold frames are available for use three or four weeks before the last freezing date.

Frames are commonly $6 \times 3$ feet and are placed in a corner of the garden containing good soil. They should be made preferably of planks, although ordinary boards will suffice, and should be at least a foot high at the back and eight inches at the front, the slope being towards the sun. It is well to have the frames banked up around the sides with earth or manure.

A cold frame may be covered with an ordinary hot bed sash, but there are several substitutes on the market which are cheaper and about as satisfactory. One is a prepared cloth which lets in the sunlight, while keeping out the cold. Another and rather more durable substitute is made of fine wire, the openings of which are filled with a material resembling celluloid. These substitutes are much lighter than glass, and for that reason easier to handle. They are coming into somewhat general use, even among commercial growers, and are admirably adapted for the needs of amateurs. For that matter, though, an unused double window or any discarded sash may be made to serve the desired purpose. It is not necessary, of course, to make the cold frame the size mentioned above, except as a matter of convenience when using commercial sash.

Many vegetables, like cabbages, cauliflowers, Brussels sprouts, lettuce, cucumbers, corn and melons, and most of the annual flowers may be started in a cold frame a few weeks before the time for setting them in the open ground. Plants like tomatoes, peppers and egg plants which have been started in boxes in the house earlier in the season may be hardened off in a cold frame.

Seeds may be sown in the soil, in which event it is wise to spade it over as deeply as possible and to incorporate a little well rotted manure. Many skilled gardeners prefer to use flats or paper pots which are set on the ground under the sash. There is a distinct advantage in this plan because the plants can be shifted to the open ground without much disturbance of the roots. If paper pots are used, it is not necessary to remove them. Dirt bands are also often used. They are similar to paper pots, except that they have no bottoms and are set in flats or on boards. 


\section{A Worth-while List of the Most Satisfactory Garden Annuals OLD FRIENDS AND CHOICE NOVELTIES All Cheaply and Easily Raised From Seeds}

Although a number of flowering plants may be sown during February in favored localities and under good weather conditions, March is the chief month for the sowing of both annuals and perennials. Need for economy in gardens has resulted in the extended use of annuals, and, while the precision of style and coloring which results from plants raised from cuttings is admitted, equally good general effects may be secured much more simply and cheaply by raising plants from seed. There is much to be said on behalf of annuals, for their variety of habit, elegance of form and delicate blending of color are not surpassed by any other section of plants. It must not be thought, however, that because of the comparatively small amount of skill needed to grow them that little care need be bestowed on them. Cood cultivation is the keynote of success with these plants as with all others and it is a matter of considerable importance to note that where this is practised a large proportion of them remain in beauty until the extreme end of the season.

\section{PLEASE DO NOTE}

AS ONLY SUCH SEEDS AS GERMINATE WELL IN OUR OWN ESTABLISHMENT ARE SUPPLIED TO CUSTOMERS, WE WILL NOT AND CANNOT ACCEPT RESPONSIBILITY FOR FAILURE IN THE HANDS OF OTHERS WHOSE MANAGEMENT, LACK OF EQUIPMENT OR LACK OF KNOWLEDGE, MAY UNCONSCIOUSLY BE THE CAUSE OF NON-SUCCESS.

\section{Flower Seeds by Weight}

We carry large stocks of all Flower Seeds and shall be pleased to quote larger amounts of the varieties we list upon application.

\section{AGERATUM (FLOSS FLOWER)}

Blooms throughout the summer, being the most effective annual for bedding and borders.

Pkt.

Little Blue Star. A new lovely miniature variety for small beds and edgings.

Plants are compact, attaining a height of only 3 inches, and are covered

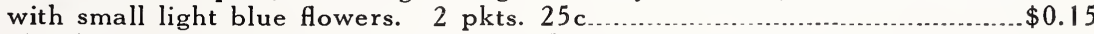

Blue Perfection. The darkest of all large flowering Ageratums. Color, deep amethyst blue; compact growth, fine for bedding. $\frac{1}{16}$ oz. 20 c......................

Scarlet Gem. (New). Very dwarf with small foliage; flowers pale rose with dark centre

\section{ALYSSUM}

Little Dorrit. A beautiful variety growing close to the ground with small white flowers; flower heads in an erect mass 3 or 4 inches high. $\frac{1}{8}$ oz. $20 \mathrm{c}$..

Little Gem or Carpet of Snow. One of the best white flowering edging plants of dwarf compact habit, 4 inches high. A solid mass of bloom from early till late. $\frac{1}{8}$ oz. $25 \mathrm{c}, \frac{1}{4}$ oz. $50 \mathrm{c}$.

Lilac Queen. A pretty, deep lavender-lilac of dwarf habit. $\frac{1}{8}$ oz. $25 \mathrm{c}, \frac{1}{4} \mathrm{oz}$. $50 \mathrm{c}$

\section{ANAGALLIS (Pimpernel) -Primrose Family}

A lovely annual from Spain you should never be without. In Spain it is a perennial and a sub-shrub; in America it grows only about a foot high and blooms all summer long until late in the fall.

A. Phillipsii, a rich deep blue, extremely showy in sunshine.

Per Pkt.

A. Mixed Varieties, beautiful rich colors; makes a lovely edging.

Either variety -2 pkts. $25 \mathrm{c} ; \frac{1}{8} \mathrm{oz}$. of each $50 \mathrm{c}$. 


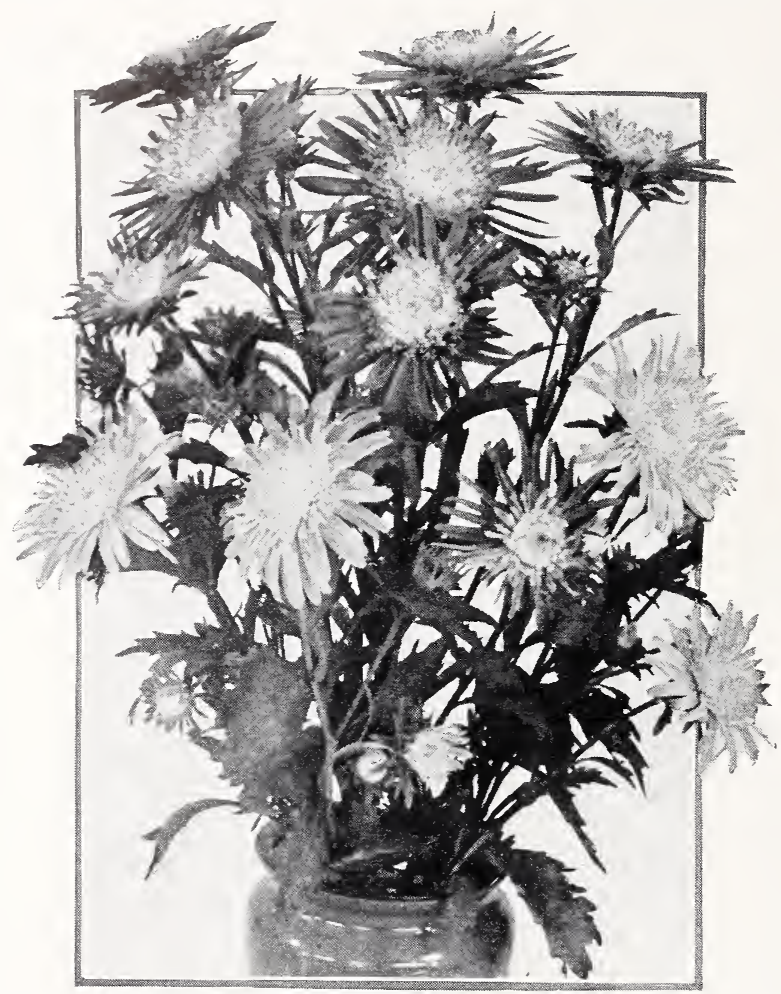

The New California Sunshine Asters

Notice the long stems

\section{CALIFORNIA SUNSHINE ASTERS}

The Sunshine type was introduced into this country a few years ago and became quite popular because of its dainty appearance. It was accepted as very desirable, but met with one objection-the flowers were borne on too short and weak stems. After several years of hybridizing and specian selection, we are now pleased to offer a new California strain, a better strain for general use. California Sunshine Asters retain their dainty appearance but are larger and are borne on long, stout stems, and the plant has the general appearance of being as robust as the Giant Washington or the Upright Branching types. The stems measure two to two and a half feet, while those of the earlier type measure aboue one and one-halft feet.

We consider CALIFORNIA SUNSHINE a distinct improvement on the original Per Pkt.

Sunshine. We offer the following colors: Pink, Carmine, Lavender and

Violet. Separate or in mixture, $\frac{1}{8}$-oz. $75 \mathrm{c}$; $\frac{1}{16}-\mathrm{oz} .40 \mathrm{c}$; any 3 colors, 3 pkts.

for $40 \mathrm{c}$; per pkt.

\section{BROWALLIA-Nightshade (Solanum Family)}

This is what we advertised under the Blue Amethyst flower. The lovely blue flowers are a joy indeed; the 12 to 18 -inch high plants bloom all summer long in beautiful sprays of violet blue flowers. Easily raised from seeds like all annuals, but slow to germinate ( 3 to 4 weeks). 


\section{CALENDULA-POT MARIGOLD}

No garden should be without these bright, showy, lovely flowers; excellent and most artistic as cut flowers, lasting a long time in the house. They withstand many light frosts. Of all varieties of Calendulas, Balls' Calendula are the best and most beautiful ones, both in color and in form.

Pkt.

Ball's Gold Calendula. A rich golden yellow; about $95 \%$ come true. Much superior to the old Lemon Queen. 2 pkts. for 25 c; $\frac{1}{8}$ oz. 75 c …........... $\$ 0.15$

Ball Calendula, Orange. This is the original Ball Calendula that has given an entirely new meaning to Calendulas with long stems and uniformly double flowers of great size. 2 pkts. for $25 \mathrm{c} ; \frac{1}{8}$ oz. $75 \mathrm{c}$

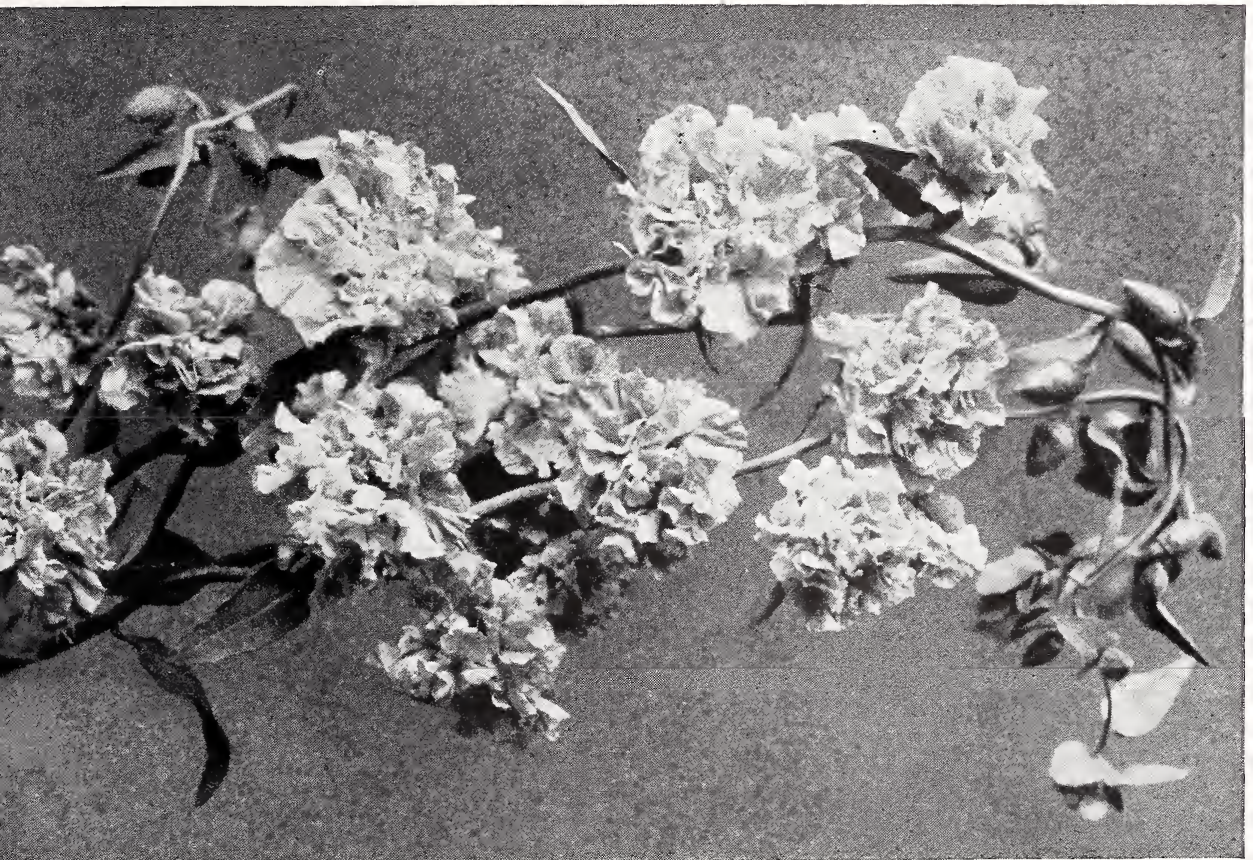

\section{CLARKIA}

\section{FLOWERS IN LONG LOOSE SPRAYS}

This pretty and easily grown annual has been much improved in recent years, and the varieties offered below are excellent for cut flowers; they do well either in sun or shade, growing 2 to $2 \frac{1}{2}$ feet high, with leaf racemen of double flowers, which all open in water when cut.

Pkt.

Ruby King. Brilliant rich ruby red, double and produced in long sprays.

An indispensable variety for the garden. $\frac{1}{8} \mathrm{oz} .25 \mathrm{c}$

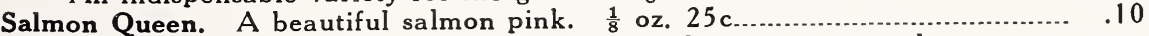

Scarlet Queen. (New) Fine double, brilliant salmon-orange-scarlet, a most

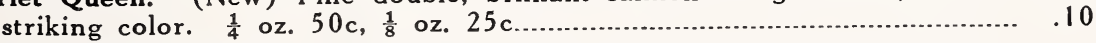

English Brilliant Mixture. A selection of the finest double varieties; all inferior colors being excluded. $\frac{1}{8}$ oz. $25 \mathrm{c}, \frac{1}{4}$ oz. $50 \mathrm{c}$. 


\section{CANDYTUFT}

Giant Hyacinth-flowered or Improved Empress. A wonderfully improved strain of the popular Empress Candytuft, forming much branched plants about 18 inches high, each branch terminated by an immense spike of very large individual pure white flowers. Makes a very effective white bed or border, and is invaluable for cutting. $\frac{1}{4}$ oz. $50 \mathrm{c}$

Rose Cardinal. Brilliant deep-rose-red; very effective for bedding. $\frac{1}{4}$ oz. $50 \mathrm{c}$

Queen of Italy. An exceedingly free-flowering dwarf, compact variety with almost everygreen foliage; may be grown as annual or biennial; valuable for cutting purposes. $\frac{1}{4}$ oz. $50 \mathrm{c}, 3$ pkts. for $25 \mathrm{c}$

\section{CENTAUREA-IMPERIALIS (SWEET SULTAN)}

This is a lovely, sweet-scented and attractive half-hardy annual for the border, providing graceful flowers for cutting, of exquisite shades, which last a long time in vases. They are so fine that no garden should be without a few plants. Sow in the open ground in April.

Per Pkt.

Favorita. Brillian rose, fancy colors.

Gigantea Alba. Giant white Sweet Sultan. New.

Iphigenia. Delicate pink with white center.

Graziosa. Intense dark lilac.

Best Mixture. $\frac{1}{16}-$ oz., 20c; pkt. of any 3, 25c

\section{COSMOS}

New Double Early-flowering Hybrids. The flowers of these new hybrids measure 3 to 4 inches across. About 60 to 70 per cent of the seedlings produce small petals instead of stamens, thus forming handsome double blooms. They supply a fine range of colors; all shades from white to pink, rose, carmine, and blood-red being represented. These new double Cosmos are of the true early-flowering type, blooming from June to October. $\frac{1}{8}$ oz. $25 \mathrm{c}$

Praecox fl. pl. Of somewhat dwarfer habit of growth, but more free flowering than the early flowering hybrids. The flowers borne on long stalks, are fine double and measure $3 \frac{1}{2}$ to 4 inches across; rose and lilac shades are predominate, but also white and carmine are met with. About $40 \%$ come double. 3 pkts. for $60 \mathrm{c} ; 1 \frac{1}{16}$-oz. $\$ 1.00$

\section{CYNOGLOSSUM-AMABILE BLUE}

This annual was recently introduced from China. It is very hardy, of easy culture, and can be grown successfully in warm climates where the ordinary Forget-me-not or Myosotis cannot be grown in the open. The flowers are of a beautiful shade of blue and resemble the Myosotis very closely. It grows on tall, graceful branches as they bloom and it will flower continually throughout the summer. It is ideal for bedding as well as for cut flowers. The color is a deep, Mysotis blue. $\frac{1}{8}$-oz. 40c., 2pkts. 25c 


\section{DIMORPHOTHECA-STAR OF THE VELDT}

One of the quickest blooming annuals, often flowering within six weeks from seed. Produces a wide range of lovely colors, which harmonize most beautifully. It requires an open sunny situation and in such will bloom all summer. It also makes a charming pot plant, by planting a few seeds in a large pot, and then thinning out to 3 or 4 plants. Flowers will be greatly improved in size and brilliance by watering the plants frequently with weak liquid manure.

Pkt.

Aurantiaca Hybrida, Fl. Pl. New. Various-colored hybrids of this flower which are quite as strong growing as the type, and include a wide range of shades of primrose, apricot, buff and salmon-orange as well as delicately tinted white flowers, many double and semi-double. $\frac{1}{8}$ oz. $40 \mathrm{c}$; 2 pkts. for $25 \mathrm{c}$

\section{ESCHSCHOLTZIA-HARDY CALIFORNIA POPPIES}

From the original golden yellow California poppy there have now been evolved the most lovely colors imaginable, from pure white to the deepest crimson-all exceedingly beautiful varieties. They make indeed a most gorgeous effect in the garden, blooming all through the summer months, from seeds sown in the open ground early in the spring, and thereafter take care of themselves for years to come, by self-seeding, and from the plants, which are really true perennials. Some of the new colors are still quite rare.

Crocea, Fl. Pl. Very fine double large orange flowers, almost like a Marechal

Neil Rose; extra select. $\frac{1}{4}$ oz. $50 \mathrm{c} ; \frac{1}{8}$ oz. $30 \mathrm{c} \ldots \ldots . . . . .15$

Enchantress. One of the most charming of all Eschscholtzias. The color on the outside of the petals is soft rosy carmine; on the inside a lighter tone of rosy carmine heavily overlaid cream. The flowers are double, and of exquisite form. This variety will be admired by everyone. It is of ver robust habit, and more floriferous than any of the varieties at present in cultivation. $\frac{1}{16}$-oz., $40 \mathrm{c} ; \frac{1}{8}$-oz., $75 \mathrm{c}$

The Geisha. Outside orange crimson, inside a deep golden yellow. This beautiful variety received an award of merit from R. H. S. of England. $\frac{1}{4}$ oz. $50 \mathrm{c} ; \frac{1}{8}$ oz. $30 \mathrm{c}$.

Golden West. A clear golden yellow. $\frac{1}{4}$ oz. $30 \mathrm{c}$

Gaiety. Deep crimson, inside of petals white. $\frac{1}{4}$ oz. $50 \mathrm{c} ; \frac{1}{8}$ oz. $30 \mathrm{c} \ldots \ldots \ldots \ldots \ldots \ldots . . . . .$.

Mikado. Intense crimson scarlet. $\frac{1}{4}$ oz. $50 \mathrm{c} ; \frac{1}{8}$ doz. $30 \mathrm{c}$.

Orange King. Very large flowered, deep orange color. $\frac{1}{4}$ oz. $50 \mathrm{c} ; \frac{1}{8}$ oz. $30 \mathrm{c}$.

Special Mixture, including all the new shades, which create a most brilliant display. 1 oz. $\$ 1.50 ; \frac{1}{4}$ oz. $40 \mathrm{c} ; 3$ pkts. $25 \mathrm{c}$.

\section{DO NOT FAIL TO HAVE SOME OF THESE BEAUTIFUL NEW CALIFORNIA POPPIES IN YOUR GARDEN NEXT SUMMER.}

\section{ANNUAL FLAX - LINUM}

As no garden should be without a few plants of the lovely perennial sort "NARBONESE," so no garden should be without a good showing of the annual.

Grandiflorum, the Carmine Flax. A wonderful, very showy soft red color; a real carmine, blooming throughout the whole summer. Many visitors who had never seen it, spoke of its appealing, charming color and habit of growth; 12 to 18 inches high. $\frac{1}{4}$ oz. $25 \mathrm{c}$.

\section{GYPSOPHELIA-ANNUAL BABY'S BREATH}

Quite as useful as the perennial sorts and fine for sweet peas and carnations. Height 18 inches. By making 2 or 3 sowings during the season you are assured of a continued supply of these lovely flowers. Quick to grow and easy to raise. Elegans White.

Elegans Deep Pink. A charming deep pink variety, which you should grow.

Either of the above, $\frac{1}{2}$-oz. $35 \mathrm{c} ; \frac{1}{4}$-oz. $25 \mathrm{c}$ 


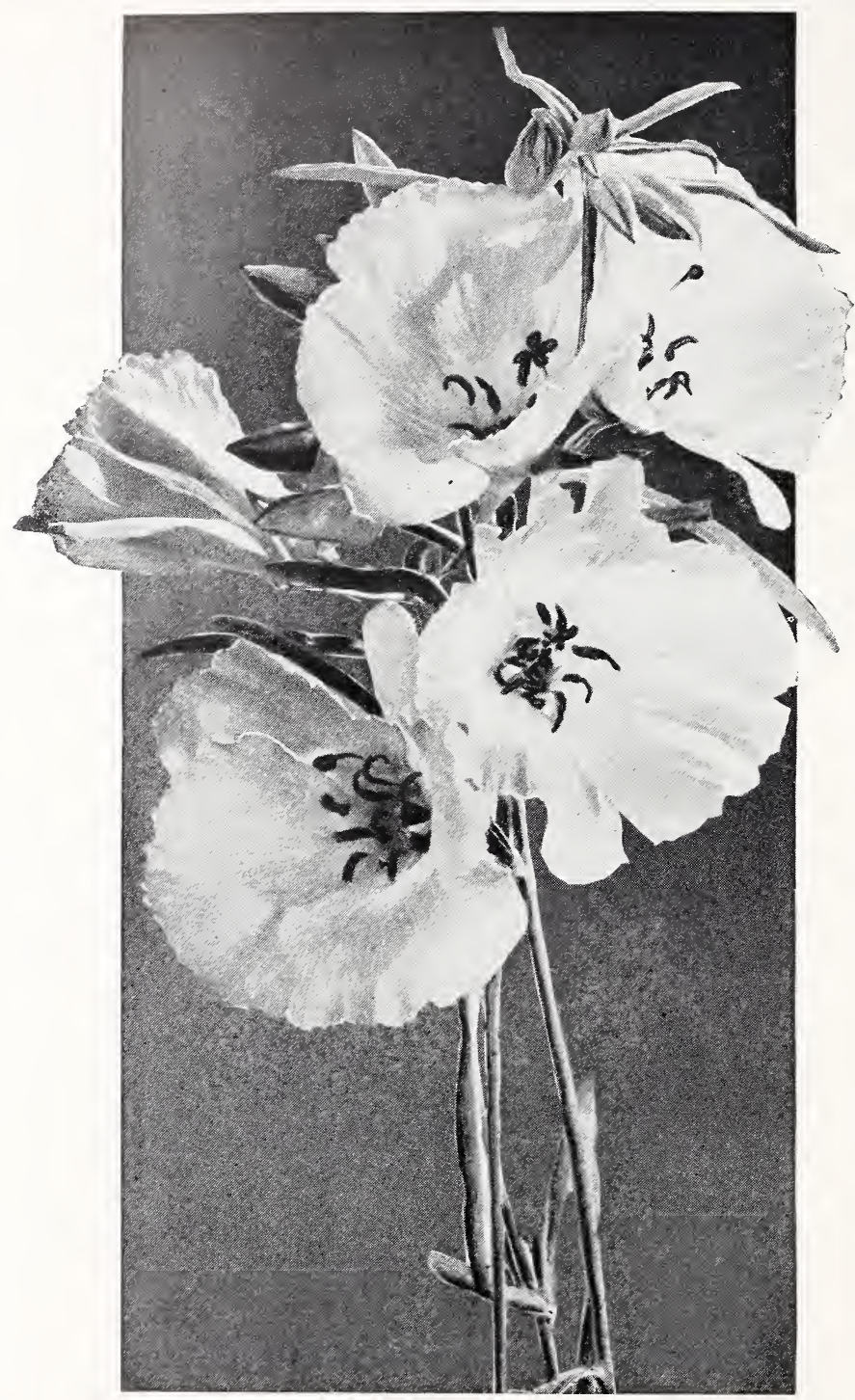

\section{GODETIA-GLADIOLUS FLOWERED (New)}

Of all annuals for garden decoration Godetias are unsurpassed for the brilliant effect they produce in beds and borders. They are extremely easy to grow and the plants remain in full beauty for a long period. When cut, the long graceful sprays of the tall varieties make a handsome decoration for vases, and this section is also largely employed as a background to borders of the dwarfer-growing kinds. They do best in a rather poor, sandy location.

TALL VARIETIES WITH FLOWERS IN LONG, LOOSE SPRAYS

Double Crimson Glow. Dazzling intense crimson. $\frac{1}{16}$ oz. $25 \mathrm{c} \ldots \ldots \ldots . . . . . . . . . . . . \$ 0.10$

Double Deep Carmine Rose. Very fine double flowers. 2 to 3 feet. $\frac{1}{16} \mathrm{oz}$. $25 \mathrm{c}$

Mixed. Finest tall double, many beautiful colors. $\frac{1}{8}$ oz. $25 \mathrm{c}$ 


\section{HUNNEMANNIA \\ (Poppy Family)}

Fumariifolia. A glorious yellow biennial $1 \mathrm{ft}$. high with lovely California poppy-like foliage, but its finely cut leaves come clear up the flower stem, making a most charming cut flower, lasting many days. Blooms easily from seeds within a few months and in mild climates will live

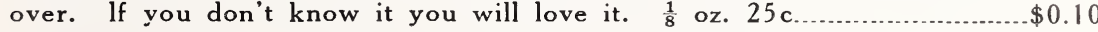

\section{IONOPSIDIUM ACAULE-VIOLET CRESS Cruciform Family}

To those who delight in growing miniature plants this charming little Portugese annual makes a very welcome appeal. It is known, also, as the Violet Cress. Growing only 2 inches to 3 inches high, this neat little plant, bearing pale mauve or lilac coloured flowers, is exceedingly pretty. Although it spreads freely wherever sown, it never becomes a nuisance, and may be associated with the choicest Alpines or other dwarf plants. It is particularly suitable for sowing in the rock garden, in crevices at the sides of paved walks, or in the chinks of rough steps. It also forms a useful subject for carpeting beneath other dwarf plants of not too dense growth, the slight shade afforded by the latter giving it protection from the hot sun. A somewhat shady situation is favourable to it. Seed may be sown almost at any time. If sown in the spring it may be expected to flower in about two months. An autumn sowing will provide a good crop of blossoms next season. After once sowing, the plants often reproduce themselves from self-sown seeds.

Per Pkt.

$\frac{1}{16}$ oz. $30 \mathrm{c}$

.15

\section{LACE FLOWER-DIDISCUS}

Lavender Lace Flower. $3 \mathrm{ft}$. long-stemmed; look like blossoms of Queen's Lace Handkerchief. A constant bloomer. The culture is not difficult, only the seeds are somewhat slow in starting. You must sow them where they are to flowerl 2 pkts. for $25 \mathrm{c} ; \frac{1}{8}$ oz. $50 \mathrm{c}$.

\section{LEPTOSIPHON-PHLOX WORTS (Polemonium Family)}

The French hybrids are gems for the rock garden; height only 4 inches. Sow where they are to flower and thin out.

L. Roseus-Beautiful species; the best. Color, deep rose. 2 pkts. 25 c Per Pkt.

L. New French Hybrids-Finest colors mixed. $\frac{1}{16}$ oz. $25 \mathrm{c} \ldots \ldots$

\section{HERE IT IS DES LIMNANTHES-TROPAEOLACEA Indian Cress Family OUR PREMIUM ANNUAL FOR 1930}

DOUGLASII, white and yellow, cream-cup; large flowered variety, exceedingly pretty. Now all this may mean nothing to you, but let us tell you that when we saw one plant of it in a rockery in Seattle two years ago we were simply charmed with it; the lady did not know its name, called it California cream-cup; last year we grew it extensively in our garden and there was not one visitor who had ever seen it before and all were charmed with it and noticed it immediately; it certainly was an outstanding novelty, at least, in our gardens. The plant rather creeps on the ground, about 6 inches high with beautiful green cress-like foliage and the flowers which are freely born are white and yellow and most appealing. You will surely love it, as we do. We grew it around a large pool and some plants in the rockery. In order to introduce this lovely annual to our many customers and friends we will give a large trial package to all those who furnish us with three names of bona fide garden owners in their town. Please call our attention to it.

Per Pkt.

Price, $\frac{1}{8}$ oz. $25 \mathrm{c}$ 


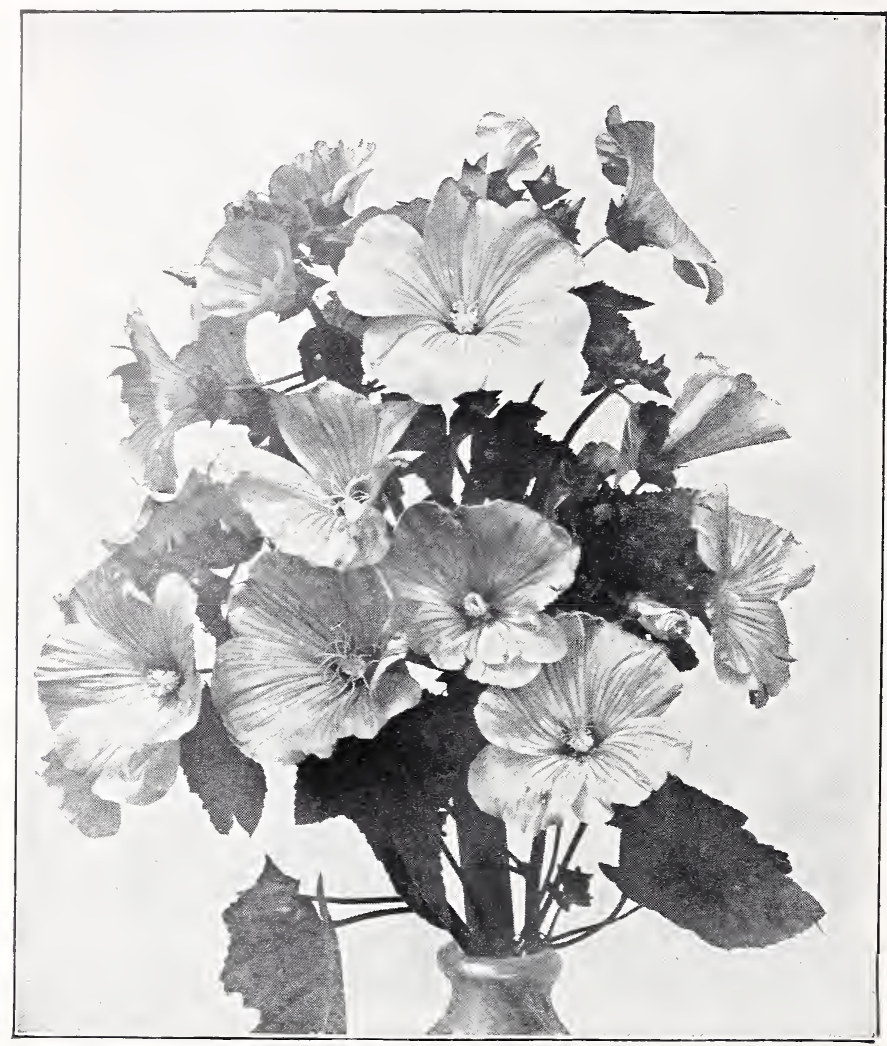

\section{LAVATERA (Mallow)}

They are particularly useful for indoor decoration. Some of the modern varieties are very good, the flowers being rich in colour, and deserving of extended cultivation. One of the foremost varieties among the hardy annual LAVATERAS is rosea splendens; this variety possesses excellent qualities as a garden plant, besides being very useful for cutting, the blooms lasting in good condition for a considerable time. Growing about 3 feet high, with large, brilliant rose-pink flowers, it is very effective. Seeds per pkt., 15c; 2 for 25c. Another form of splendens, called Sunset, has deep rose-pink flowers and grows about $2 \frac{1}{2}$ feet high. Seeds per pkt., $15 \mathrm{c} ; 2$ for $25 \mathrm{c}$.

L. trimestris, a South European annual, of similar height to the preceding, bears large, pale rose coloured flcwers, and very useful as a border subject. I have never known Lavatera trimestria to be so fine. I have a fine hedge, literally, of this beautiful Mallow, which, by actual measurement, is 8 feet 9 inches in height, and which is simply a mass of bloom. It surpasses anything which I have previously had. The hedgs is 25 yards in length, and is, at the time of writing, more showy even than Sweet Peas. Seeds, per pkt. 15c; 2 for 25c.

The annual Mallows transplant rather badly, therefore seed is best sown where they are intended to flower. They thrive in rich and somewhat light soil, which should be well prepared before sowing the seed. Plenty of space should be given the plants for development, the height being indicative of the distance to allow.

L. Olbia. One of the best among the perennial species. This forms a neat, pyramidal bush four feet to five feet high, with sprays of clear, rose-pink flowers freely produced. It makes a bold and effective subject for the flower border or in the shrubbery. Small plants grown in pots are employed very largely for indoor decoration, for which purpose it is extremely useful. Seeds, 2 pkts. for $25 \mathrm{c}$. 


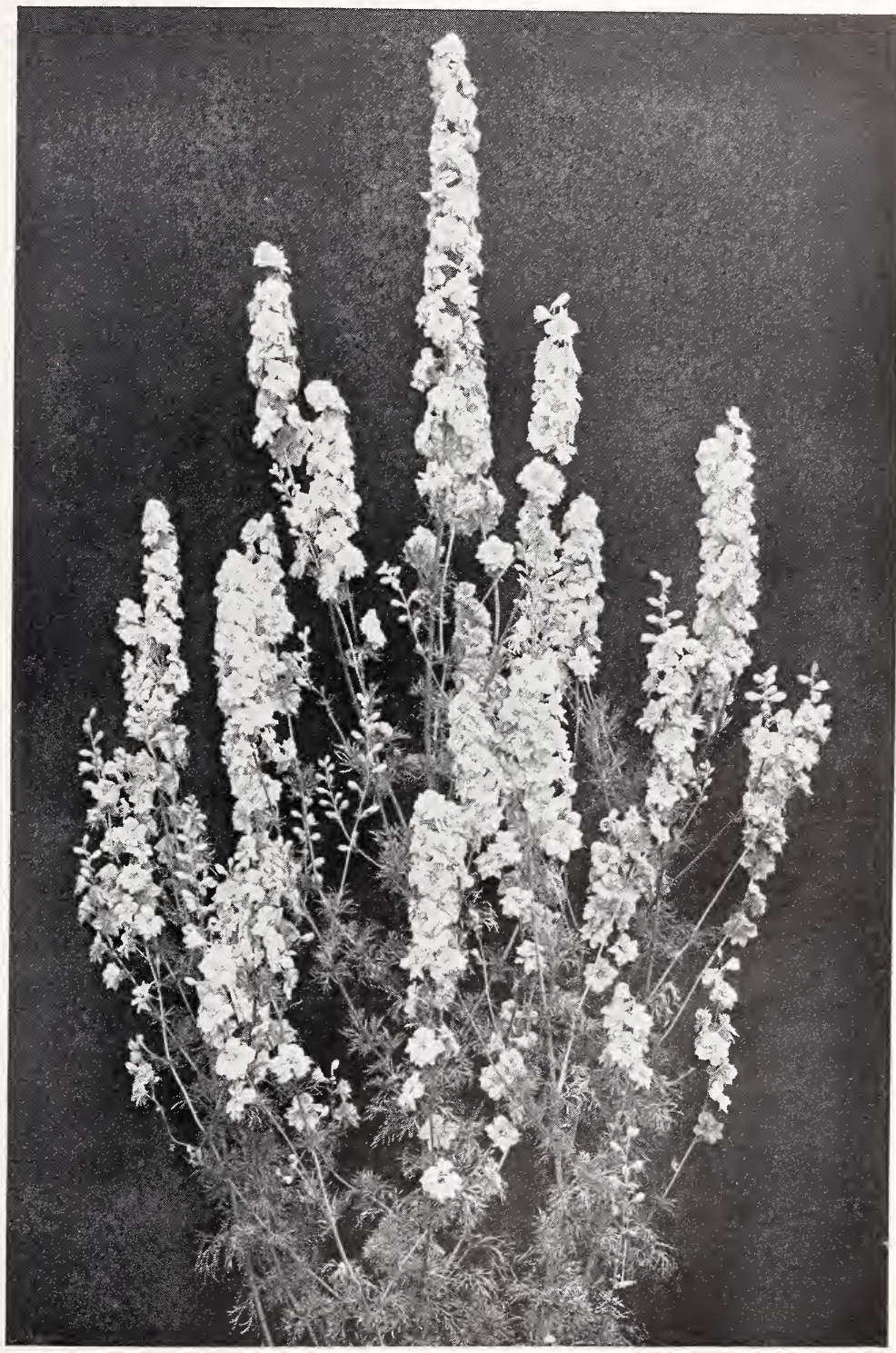

A SINGLE SPECIMEN PLANT "PINK ANNUAL LARKSPUR"

For description turn over. 


\section{ANNUAL LARKSPURS}

One of the best and also one of the oldest garden plants for summer flowering is the annual Delphinium, or Larkspur, as it is more commonly called. It is so simple to grow that it calls for little comment. These handsome subjects are widely grown and fully deserving of a permanent place in every garden. If planted at the back of herbaceous borders or in front of shrubberies and similar places they are most effective and are also extremely valuable for supplying cut flowers for the decoration of dwelling rooms.

We are referring to the varieties which grow about three feet high, and the two best we have in mind at the moment are the deep blue and rosy-scarlet. They are most effective if grouped together and are bound to command admiration.

Both plants are perfectly hardy and are best sown where they are to bloom. Larkspurs form tap roots and do not develop many fibrous roots; if for that reason alone, they should be planted in their permanent quarters when they are very small.

\section{LARKSPUR-ANNUAL DELPHINIUMS}

Not to be confused with the perennial Delphinium which is quite a different thing. For a description of the latter see pages 9 to 21 . These annual Larkspurs produce fine spikes, most graceful and attractive. They grow from 2 to 3 feet high. The tall stock-flowered are the finest varieties for beds and for cutting.

“Sky-Blue." $\frac{1}{8}$ oz. $25 \mathrm{c}$

La France. A beautiful shade of salmon pink; an outstanding novelty of the

season. $\frac{1}{4}$ oz. $75 \mathrm{c} ; \frac{1}{8}$ oz. $50 \mathrm{c} ; 2$ pkts. for $25 \mathrm{c} \ldots . .15$

"Rosy Scarlet" (New). A wonderful color in Larkspurs. 2 pkts. 25c.......... .15

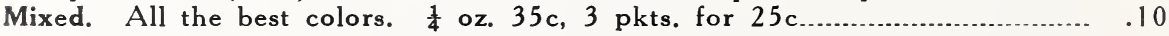

\section{AFRICAN MARIGOLDS}

A carefully-selected strain, the best to be had. African Marigolds with their self-colored globular heads of striking orange and lemon-yellow flowers, if allowed to grow naturally, are an adornment to any garden, and produce a vast wealth of color. Culture directions for growing the finest Marigolds will be found on the reverse of each seed package.

Prince of Orange. Deep orange-yellow flowers of a perfectly globular forma-

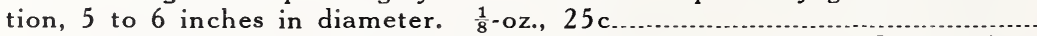
Per Pkt.

Lemon Queen. Clear lemon-yellow, a remarkably fine variety; flowers 5 to 6 inches in diameter, globular in form, beautifully finished. Price per pkt., etc., same as above.

French Dwarf Double Marigolds. Wonderful, dark rich and golden colors, spotted and striped; finest mixed. $\frac{1}{8}$-oz., $25 \mathrm{c}$..

\section{MYSOTIS-FORGET-ME-NOT}

No garden should be without this lovely, loveable thing; whether you use it as a border plant, for a ground cover over your tulips or on the border of your brook or pool (where it is most at home) anywhere it is a joy. Did you ever fill a shallow bowl with the cut flowers (cut it while still in bud). lt makes a lovely decoration, and by using it with Lilies of the Valley, you will have a bouque of exquisite, dainty loveliness. By the way, every garden should contain a few clumps of Lilies of the Valley, also.

The following two varieties are the best for garden use. Plants bloom the same season from seed; renew your plants every season, or they will self sow.

Sutton's Royal Blue. Very early, free flowering, deep indigo blue, from special

selected stock. Seeds are very small. $\frac{1}{16}$ oz. $35 \mathrm{c} ; 2$ pkts. $25 \mathrm{c}$

Ruth Fisher. Large flowered blue ; one of the finest. Seed very scarce.

$\frac{1}{16}$ oz. $\$ 2.00$

"June rear'd that bunch of flowers you carry,

From seeds of April's sowing."

-Robt. Browning. 


\section{TOM THUMB NASTURTIUMS}

Empress of India. A border 150 yards in length was smothered with its deeply crimson flowers. Leaves are dark. Certainly an outstanding Tom Thumb variety.

Aurora. Apricot, very beautiful.

Golden King. Deep golden yellow.

Cloth of Gold, golden foliage with brilliant scarlet flowers.

Prices of seeds of any of the above-NOT IN MIXTURE-1 oz. $25 \mathrm{c}$

\section{NIGELLA (LOVE-IN-A-MIST)}

Miss Jekyll. This lovely variety will give you an abundance of long-stemmed, clear corn-blue flowers, prettily set in dainty foliage. It is a treasure, indeed, and one of the finest annuals for the garden. The plants are very hardy, and if possible, seeds should be sown in the fall, producing the best flowers the following summer, but an early spring sowing is equally good. $\frac{1}{4}$ oz. $50 \mathrm{c} ; 2$ pkts. $25 \mathrm{c}$.

\section{NEMOPHILA (BABY BLUE-EYE)}

A lovely low growing hardy annual with pretty foliage extensively used for ribbon borders and general garden decoration. Sow it liberally; you will love it.

Insignis Blue. Beautiful color; height 6 Pkt.

Insignis Blue. Beautiful color; height 6 inches. $\frac{1}{2}$ oz. $50 \mathrm{c} ; \frac{1}{4}$ oz. $30 \mathrm{c} \ldots \ldots . . .10$

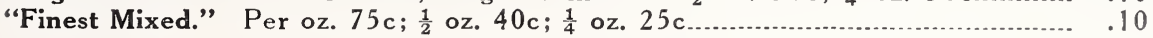

\section{PANSY SEEDS}

Heinr. Mette's (Germany) Triumph of the Giants, awarded prizes wherever shown.

The plants distinguished themselves by their robust growth, and firm, compact bushes of round shape, with strikingly large, healthy-looking foliage.

The imposing five-spotted flowers which on long, vigorous stalks surmount the foliage in the most graceful manner, are of enormous size, perfectly round form, original structure, and unusual substance. The individual petals are exceedingly broad and cover each other in such a manner as to make the flowers appear almost double. With most of the flowers the border of every petal being conspicuously undulated and curled, which grants the flower a striking and very peculiar appearance, entirely new to this class of plants.

The beauty, brilliancy and richness of color being the most striking; also very rare and new tones of red and brown are met with in these flowers.

Anyone growing these Pansies will declare them to be the most perfect and wonderful Pansies they have ever seen. $\frac{1}{16}$-oz., \$1.00. Pkt. of 200 seeds.. $\$ 0.50$

For those who prefer a very fine American Pansy strain, we offer this season: Steele's Mastodon Miracle. Mixed; contains all the finest types and latest novelties. $\frac{1}{16}$ oz. $\$ 1.00 ; \frac{1}{8}$ oz. $\$ 1.75 ; \frac{1}{4}$ oz. $\$ 3.00 ;$ pkt. of about 200 seeds

\section{PETUNIAS}

P. Hybrida Pendula ("Balcony Petunia"). A beautiful bright blue.

Balcony Petunia "Rosy Morn." A bright rosy pink. 3 pkts. 50c.

Feltham Beauty (Nana compacta). (New). A great variety of color, ranging from white to deepest rose; height $1 \mathrm{ft}$. Throws a small per cent of double flowers. $\frac{1}{16}$ oz. $\$ 1.00$. 


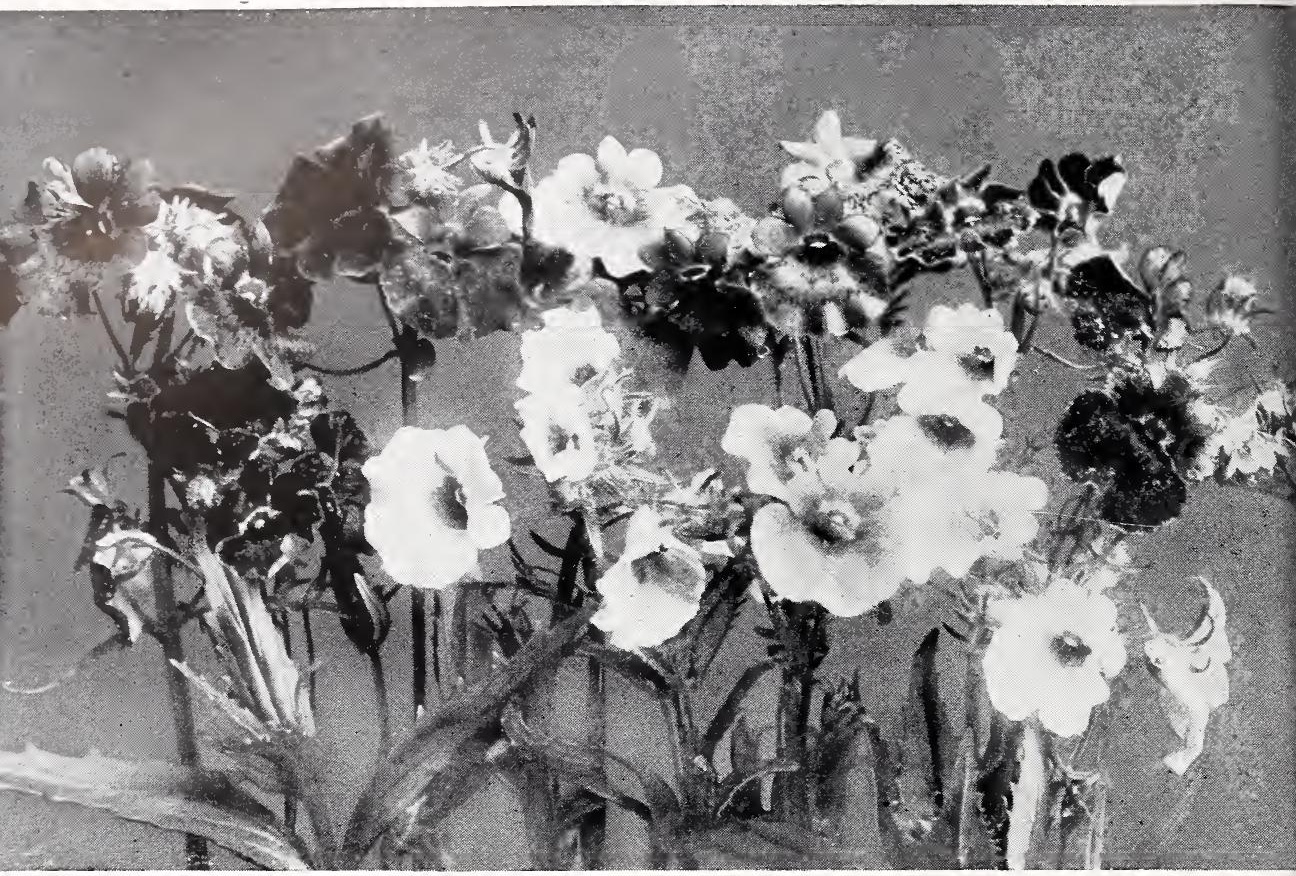

\section{NEMESIAS}

These attractive, charming flowers are grown in England and Scotland as freely as Nasturtiums, coming some 30 years ago from South Africa. They are easily raised from seeds, which germinate quickly when sown in boxes or right in the beds; the plants should be planted about 6 inches apart each way. Pkt.

Sutton's Large-Flowered in mixed colors of white, pale yellow, pink, crimson, and many beautiful intermediate shades. These Nemesias will make

a perfect blaze of gorgeous colors in your garden. 2 pkts. for 25 c...........\$0.15

Hybrid "Blue Gem." This popular dwarf, compact Nemesia is a gem, indeed; very beautiful for edgings or pot culture; a lovely forget-me-not blue. You must try these Nemesias, both the dwarf and Nemesia Suttoni. 2 pkts. for $25 \mathrm{c}$

\section{PHLOX DRUMMONDI GRANDIFLORA}

The annual Phlox is a native of Texas, and is known as "Texa Pride." It occupies a first place as a garden annual, being one of the most brilliant and at the same time one of the easiest and most satisfactory plants which can readily be grown from seed. It will grow and thrive in any kind of soil if given a sunny position, but prefers a light, rich loam. Seed may be sown in the open ground any time after frost is past, and in a few weeks they are a sheet of bloom, remaining so until frost. They may be used in a veriety of ways, such as a carpet to beds of roses, in boxes, vases, etc.; but it is when grown in masses, in beds or borders, that they show to best advantage.

Pkt.

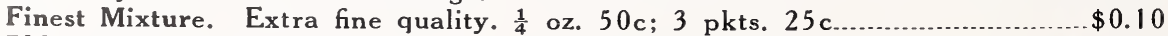

Phlox Drummondii Nana Compacta. Dwarf, compact varieties.

Fireball. Dazzling scarlet. $\frac{1}{8}$ oz. $50 \mathrm{c} ; 2$ pkts. $25 \mathrm{c}$

Carminea Stellata. A mass of brilliant carmine flowers with star shaped center. $\frac{1}{8}$ oz. $75 \mathrm{c} ; 2$ pkts. $25 \mathrm{c}$.

Caerulea Stellata. Light blue with white star shaped center. $\frac{1}{8}$ oz. $75 \mathrm{c}$; 2 pkts. $25 \mathrm{c}$

Phlox Drummondii Nana Compacta Grandiflora, Cecily Mixed. Containing many beautiful colors. $\frac{1}{4}$ oz. $\$ 1.00 ; \frac{1}{8}$ oz. $60 \mathrm{c} ; 2$ pkts. $25 \mathrm{c} \ldots \ldots$ 


\section{PHACELIA-CAMPANULARIA}

A beautiful, lovely annual! the finest of all blue annuals; a rich, deep, gentian-blue. It is not known as it should be; it grows anywhere, is hardy and strong, and makes a lovely border, or a charming bed. Sow it liberally-you will love it. Light soil, sunny position; height 9 in. $\frac{1}{8} \mathrm{oz}$. $35 \mathrm{c} ; \frac{1}{4}$ oz. $60 \mathrm{c} ; 2$ pkts. $25 \mathrm{c}$

\section{SALPIGLOSSIS VARIABILIS SUPERBISSIMA}

\section{(Emperor Painted Tongue)}

The largest flowered and most beautiful of all varieties.

These are one of the very finest annuals, and are of the easiest culture, succeeding in any good ordinary soil and in a sunny position. The plants grow from 24 to 30 inches high, and produce freely from midsummer until frost their attractive Gloxinia-like blossoms in a very large and unusual range of colors. They are splendid for cutting, lasting well. Seed may be started indoors or in a hotbed about the end of March, or sown outdoors when danger from frost is passed and the ground is in good condition. For best results the plants should not be set closer than 12 inches apart.

Mixed-All the finest colors, including blue and gold, golden yellow, crimson gold veined, rich purple, velvety red; all mixed. $\frac{1}{8}$ oz. $75 \mathrm{c} ; 2$ pkts. $25 \mathrm{c} \ldots \ldots 0.15$

\section{DOUBLE ANNUAL SCABIOSUS}

New Tall Large Flowering. This new race marks a great improvement on existing kinds. The plants are stronger growing, and the flowers ever so much larger than anything seen heretofore, and most useful for cutting. A valuable acquisition for your garden.

Peach Blossom. A beautiful shade of peach blossom pink, large size and strong stems; an excellent cut flower. $\frac{1}{8}$-oz., $50 \mathrm{c} ; 2$ pkts. for $25 \mathrm{c} \ldots \ldots . . . . . .$.

Shasta. A pure white of great size, flowers often measuring three and a half inches across with very long stems.

Azure Fairy. Pale blue, very fine and very double. This variety obtained a Reward of Merit from the Royal Horticultural Society of England, a great honor.

Crimson. A beautiful rich shade of deep crimson or carmine. Any of the

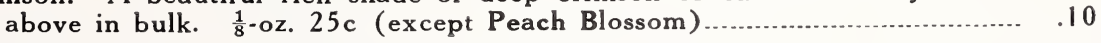

Mixture, containing all the above and other colors. $\frac{1}{8}$-oz., $25 \mathrm{c} \ldots \ldots \ldots \ldots \ldots \ldots \ldots \ldots \ldots . . . . . . . . . . .10$

\section{SCHIZANTHUS-BUTTERFLY FLOWER Scrophulariaceae Family}

The Schizanthus are a very different matter altogether. I have heard of garden makers who sow the seeds in the open and reap rich rewards; but 1 must confess they are more skillful than I. Only seeds carefully sown in sandy seed pans early in the year have brought joy into my garden. These butterfly flowers are so dainty, and at the same time such a delicately tinted mass of bloom, they are well worth extra trouble. Being only half hardy, these seeds need an indoor start. These are much grown as winter hothouse flowers, and they may be potted off at the end of summer to be brought indoors as house plants before frost. They are natives of Chile and worshippers of the sun. Their preference is for a rich garden loam.

Dr. Badger's Hybrids. Large flowered, excellent and very varied colors. Per Pkt. $\frac{1}{16}$ oz. $50 \mathrm{c}$ 


\section{VISCARIA}

If you have never grown this lovely dwarf annual you will certainly be glad to have your attention called to it. The plants bloom all summer long till late in the fall and are most attractive when planted in masses or along paths. Height 6 to 8 inches.

Pkt.

V. Tom Thumb Rosy Gem. The attractive brilliant carmine-rose flowers appear in great profusion. 2 pkts. for $45 \mathrm{c}$

V. Tom Thumb Blue Gem. Bright blue flowers, a charming plant. 2 pkts. $45 \mathrm{c} .25$

V. Choice Mixture, comprising many pretty colors. $\frac{1}{4}$ oz. $25 \mathrm{c}$

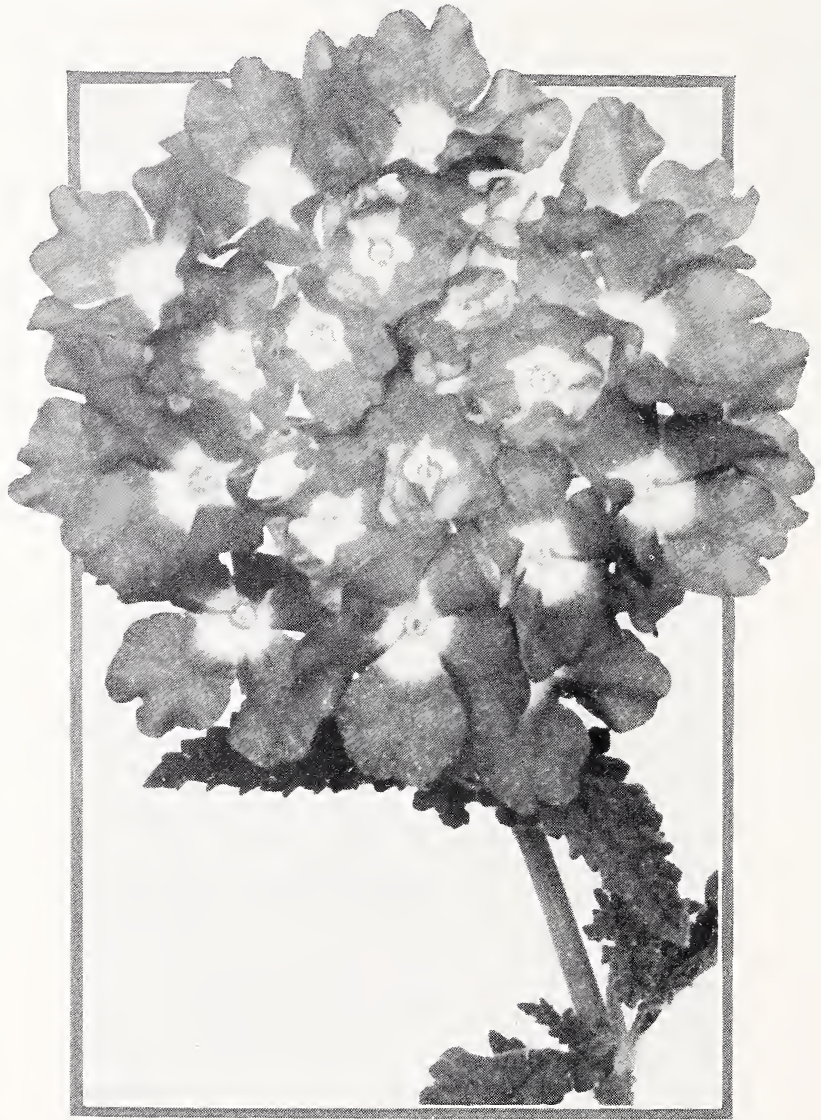

\section{VERBENA-MAMMOTH GOLDEN QUEEN}

As in Asters, a clear Golden Yellow is very difficult to produce in Verbena, but we have, after several years of close application, succeeded in developing GOLDEN QUEEN. The flowers are of medium size and borne on a vigorous vine that is of an ever-bearing nature. It is one of the earliest of flowers and continues to develop throughout the growing season, making it a very valuable plant for bedding purposes where a good yellow is required. It is the deepest yellow on the market.

\section{Carmine Pink}

A new and bright color in the gigantea class. The flowers are large and placed in the trusses as to make them very conspicuous. They are borne on a vigorous growing vine and should make a striking effect when used as a bedder. This is the first Verbena of this particular carmine shade offered and has been accepted by many visitors who have seen it.

Seeds, $\frac{1}{8}$ oz. $50 \mathrm{c} ; 2$ pkts. 25 c. (State which color you want) 


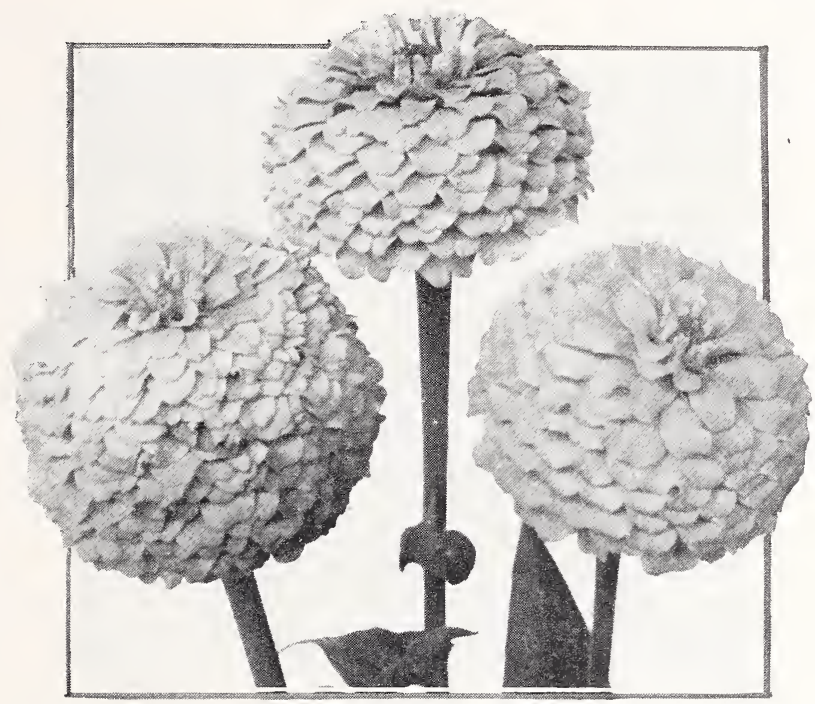

\section{ZINNIA-LILLIPUT IMPROVED}

No type of Zinnia has come into favor so rapidly as the improved strain of LILLIPUT. They are a type of plants of even height for bedding purposes, bearing small, button-like, fully double flowers of gorgeous colors. The plants will throw long stems for cutting and basket work when heavily fertilized. The best colors are: Salmon Rose, Golden Gem, Crimson Gem, Best Mixture. Seeds, $\frac{1}{2}-o z ., 75 c$; $\frac{1}{1}$-oz., $40 c$; 2 pkts., 25c; per pkt., $15 c$.

Delicate Flesh Pink (New), $\frac{1}{4-0 z ., 75 c ; ~ p e r ~ p k t ., ~} 25 \mathrm{c}$.

Meteor. A rich, glowing, deep red and the darkest of all the red shades. Fine form, with good depth of petal.

\section{A LIST OF CHARMING ANNUALS SUITABLE FOR THE ROCKERY}

Annuals in the rockery are not out of place; on the contrary, they fill an urgent want for bright blossoms, when the run of the true perennial rock plants are out of bloom, and they do not in the least interfere with your rock plants.

Give any or all of these suitable annuals a trial in your rockery this season and you will never do without them again.

Phacelia, Nemesias, especially the blue forget-me-not like type.

Viscaria, both lovely colors.

Nemophila, especially the baby-blue-eye.

Leptosiphon, Limnanthes Douglasi, Linum Rubrum, and even the dwarf Tom Thumb

Nasturtiums, are lovely subjects and very showy.

\section{WHY WE PREFER TO SELL MORE SEEDS INSTEAD OF SELLING AND SHIPPING PLANTS}

Chula Vista, California.

"l sent for plants when I wanted quick results, but now one is throwing money away when sending for plants, as the lnspectors are not careful in re-packing, and they are kept too long, so will have to rely on seed."-J. H. B.

This is not only the trouble we meet with in California but in most Eastern States. 


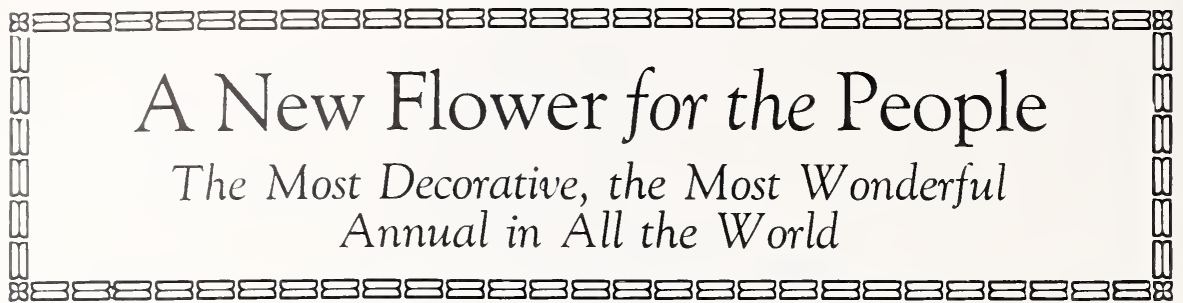

\section{The New California Dahlia-Flowered Zinnias} (Pure BODGER Strain)

In wonderful, true Pastel shades, making them distinct from the ordinary giant Zinnia.

\section{No Other Zinnia Strain Can Compare With Them Awarded the highest honors in America and England.}

\section{$0 \%$}

The large size, fullness of petals, extraordinary color range, and good keeping qualities of this flower have all contributed to its popularity. It is easily grown, and keeps well when cut. It is immune from disease. Equally good as a garden flower and as a florist's specialty, its great popularity will increase with years to come. lt has been truthfully called "A NEW FLOWER FOR THE PEOPLE."

Sow the seeds outdoors thinly in rows when the maples are coming into leaf, or better, since the Zinnias require several months to mature, the seed may be started indoors during March and April.

\section{THE SIX BEST AND DISTINCT COLORS:}

Exquisite-Truly Dahlia-flowered as regards form and size. A light rose with center a deep rose.

Golden State-A very rich orange-yellow; yellow in the bud, turning to an attractive orange when in full bloom.

Crimson Monarch-The largest and best of the red shades. Flowers often eight inches in diameter; very vigorous; a marvellous production of greatest merit.

Oriole-An immense orange and gold bi-color, worthy of the beautiful bird after which it was named.

Meteor-A rich, glowing, deep red and the darkest of all the red shades. Fine form; with good depth of petal.

Buttercup-An immense deep, creamy yellow. A very desirable flower, which should be included in every collection.

PKT. 20c; ANY 3 FOR 50c; THE 6 NAMED VARIETIES FOR $\$ 1.00 ; \frac{1}{8}$-oz., 75c; $\frac{1}{4}$-oz., $\$ 1.00$; $\frac{1}{2}$-oz., $\$ 1.75 ; 1$ oz., $\$ 3.00$.

Special Gold Medal Mixture-Genuine Pure Bodger Strain-A well blended mixture containing all the above novelties and several other equally beautiful novelties. Per pkt. 15c; 2 pkts. for 25 c; 1 -oz., 75c; $\frac{1}{2}$-oz., $\$ 1.50 ; 1$ oz. $\$ 2.50$.

HERE IS OUR ADVICE: These Zinnias make such a gorgeous showing in your garden for weeks and months, and are such satisfactory cut-flower subjects for your house, and are great money-makers as a cut-flower, that you can well afford to buy the seeds by the ounce, half ounce or quarter ounce, the cheapest way to buy them.

\section{ORDER YOUR SEEDS EARLY AND AVOID DISAPPOINTMENT}




\title{
Our Plants and Seeds are Advertised by Our Admiring Garden Friends
}

\author{
Long Beach, California
}

The pansies and delphiniums which 1 raised from your seed last spring were indescribably beautiful.

-Mrs. E. B. B.

Owensboro, Kentucky, May 13, 1929.

Certainly I want your Iris manual. I bought quite a nice list of you last fall, and was delighted with what you sent me, and was greatly pleased when you sent me the lovely Roseway iris, gratis. I mean always to buy my iris of you if possible. Every single thing 1 have bought from you has been grand, and money could not buy better.

-Mrs. O'C. C.

Omaha, Nebraska, May 20, 1929.

1 want to say 1 am delighted with the seedlings. They arrived in excellent condition. Many thanks for the fine plants. 1 am more than satisfied with them.

-Mrs. M. McN.

\section{Statesville, North Carolina}

1 have had some remarkable blooms from delphinium plants from your seed. A florist here told me that she had seen delphiniums at flower shows, but nothing to compare with yours. I got over a hundred plants from a package of seed from $\mathrm{S}$. in England but I would give the lot for one of your exquisite Nora Fergusons. -Miss G. A.

Bound Brook, New Jersey, September 16, 1929

The three dozen delphinium seedlings just received. They are the finest 1 ever had, even from you-not a decayed leaf, but many new ones had grown on the way. Thanking you,

-Mrs. H. M. B.

\section{Ridgefield, Connecticut}

The delphinium seedlings that $I$ ordered from you this spring have been so lovely that 1 feel I must thank you for the pleasure they have given me. A judge of delphiniums said they were "superb." They are much more handsome than any I have ever grown. -Mrs. A. T. O.

\section{Dear Mr. Pudor:}

Oakland, California, July 23, 1929

Last year l sent for seed of your "Prize Winner" and "Private Wrexham Mixture" which arrived, and were planted July 25, 1928. Within twenty-eight days they were transplanted to flats, about 250 plants from 300 seed. Approximately three-fourths have bloomed, some plants the second time, at this date, July 23. They are so lovely I dream of them-after admiring them all day long! There are two plants I wouldn't part with for any consideration, and two of seven whites and ivories that are surpassingly fine-simply invaluable for the locations planned for their permanent placing. All thanks to you! A friend after seeing these plants said there was no need of looking further, and is sending to you for seed this summer. 


\section{JUST A LITTLE CHAT}

We have never understood why Thermopsis Caroliniana is not better known and more use-1. Coming as it does with the delphiniums and growing as high as the tallest of them, they make a splendid combination. It belongs to the pea family and the flowers are pea-shaped and clustered, of a very clear yellow. The foliage is also pea-like and delicate. Orange and white lilies with this and a few delphiniums would be another combination for the yellow garden.

\section{THE FORGET-ME-NOT ANCHUSA}

Not infrequently the forget-me-not anchusa (Anchusa myosotidiflora) is mistaken for a real although large forget-me-not, having exactly the same delicate blue color. The flowers are carried two feet high on stiff, wiry stems. A goodsized group of this alkanet in bloom readily arrests attention, so elegant is its growth and so delicate its color. It is essentially a plant for the mixed border, where it is most effective, grouped in the foreground. Often it seeds freely, seedlings springing up around established plants. The best return, however, is obtained from two-year-old or older plants, which flower profusely. The culture of this anchusa calls for no special treatment, it being a true perennial and perfectly hardy, not rotting away after flowering and leaving blank spaces such as $\mathrm{A}$. italica and its varieties are inclined to do.

\section{ANNUAL LARKSPUR-A Grand Cut FLOWER For Fall}

This is just a reminder that about July 1 is a good time to make a sowing of annual Larkspur outdoors. You want a good rich soil, but sow thinly. Many florists are apt to waste a lot of seed by sowing too thickly, and thereby get poor results later on. The annual Larkspur in particular should have room for development; it will mean better stems and better flowers. Seed sown about July 1 should result in good flowers during September, and with fair weather conditions you will cut away into October. Don't sow mixed seed, have the pink, blue and white separate. These Larkspurs, when in blooin in early Fall, are always useful, no matter how good your Asters or Dahlias may be. Nothing is finer for the filling of baskets, either by themselves or when used in connection with Roses, Carnations or garden flowers. They don't interfere in any way with the perennial Larkspur, but often can be used where the latter may be considered too heavy.

\section{THE PROBLEM OF THE EDGING PLANT}

For the past two seasons my garden has boasted what has seemed to me the handsomest flower edging I have ever seen, and one which I am afraid is going to be copied next summer in half the gardens of the county. I used an ounce of Alyssum seed of the variety known as "Carpet of Snow" and a quarter ounce of Lilac Queen. The lilac sort grows just enough taller than the white to give the edging a delightful irregularity in height, and the color softens and enlivens the deadness of the white, as used alone, into a pleasing tint, sometimes suggesting a delicate soft gray and again a dainty pink. Toward fall the lilac color grows somewhat stronger than earlier, probably because the colored sort holds out much better than the white.

lnnumerable people visit my garden each season, and hardly a garden owner who has seen it recently but has exclaimed over this alyssum edging and has asked the recipe for it. It will be used again this coming summer and indefinitely until the urge for a change seizes me, and then 1 suppose 1 shall turn to Violas or lobelias, for out of all the edging plants 1 have tried, or seen tried, these three come nearest the standard of perfection. (House Beautiful). 


\section{List of Choice Hardy Perennial Plants}

\section{SPECIAL NOTICE!}

All Tiny Seedlings are sent by Post, carefully packed between layers of fine moss, and at the prices quoted they are package and postage free. Some people prefer to have them sent by express, thinking the package will get more air, but the package, of course, is very small.

Owners' Risk. All plants are forwarded at Owners' Risk. The Post Office Department accepts no responsibility for damage or delay, and I certainly can not, and immediately the plants are placed in the mails or in the express office, they are at the sole risk of the consignee or purchaser.

\section{CAUTION!}

Do not order 1 dozen seedling plants to be sent by themselves-they are so small and the package so small, that it is most difficult to pack 1 dozen tiny seedlings in such a manner that they will keep moist enough for long distance shipment.

No PLANT orders are solicited for less than $\$ 1.50$, unless you add $25 \mathrm{c}$ extra for handling charges.

\section{TINY SEEDLINGS OR ADVANCED PLANTS}

Which will you have? The difference is this:-(1) If you are keen and careful, and have some previous experience of pricking out, watering, and tending the early stages of plant growth,- then the TINY SEEDLINGS will be both a JOY and a PROFIT. There is no doubt about them. They reeach you fresh and healthy, and, if you have reasonable facilities, SUCCESS IS CERTAIN. (2) lf, on the other hand, you are easy, or if the circumstances are such that you cannot give critical attention, or have not the elementary knowledge, accommodation, or facilities, - then ADVANCED PLANTS or clumps will be your best investment. These are past the critical stage, and only ordinary care is necessary to insure success, provided they are planted at the proper time.

\section{SPECIAL NOTE}

Seeds and all Unbloomed Seedlings, though offered in Separate Colors, must be accepted as from Mother plants only of the Colors indicated, with no warranty, expressed or implied, that the progeny will be constant to the parent Colors

\section{PLEASE DO NOTE}

The proportion of true Color Shades may vary from 85 to 95 per cent., the balance being recessive types of earlier parentage. If you must have exact color lines, Named Sorts (from Cuttings or Division) alone are absolutely reliable.

\section{ACONITUM (Monkshood)}

Summer- and late Autumn-flowering plants with bold spikes of hood-shaped flowers, thriving in either sun or shade. The roots are poisonous and should not be planted where the tubers might be mistaken for vegetables. Delivery from October 15th to March 15th. Tubers cannot freeze.

Wilsoni. The true variety which we are herewith offering is the late Autumnflowering kind, producing 5 to 6 tall spikes covered with beautiful mauve colored flowers. It is a very rare variety. We advise giving it a little protection during the Winter. 35c each; 3 for $\$ 1.00$. 


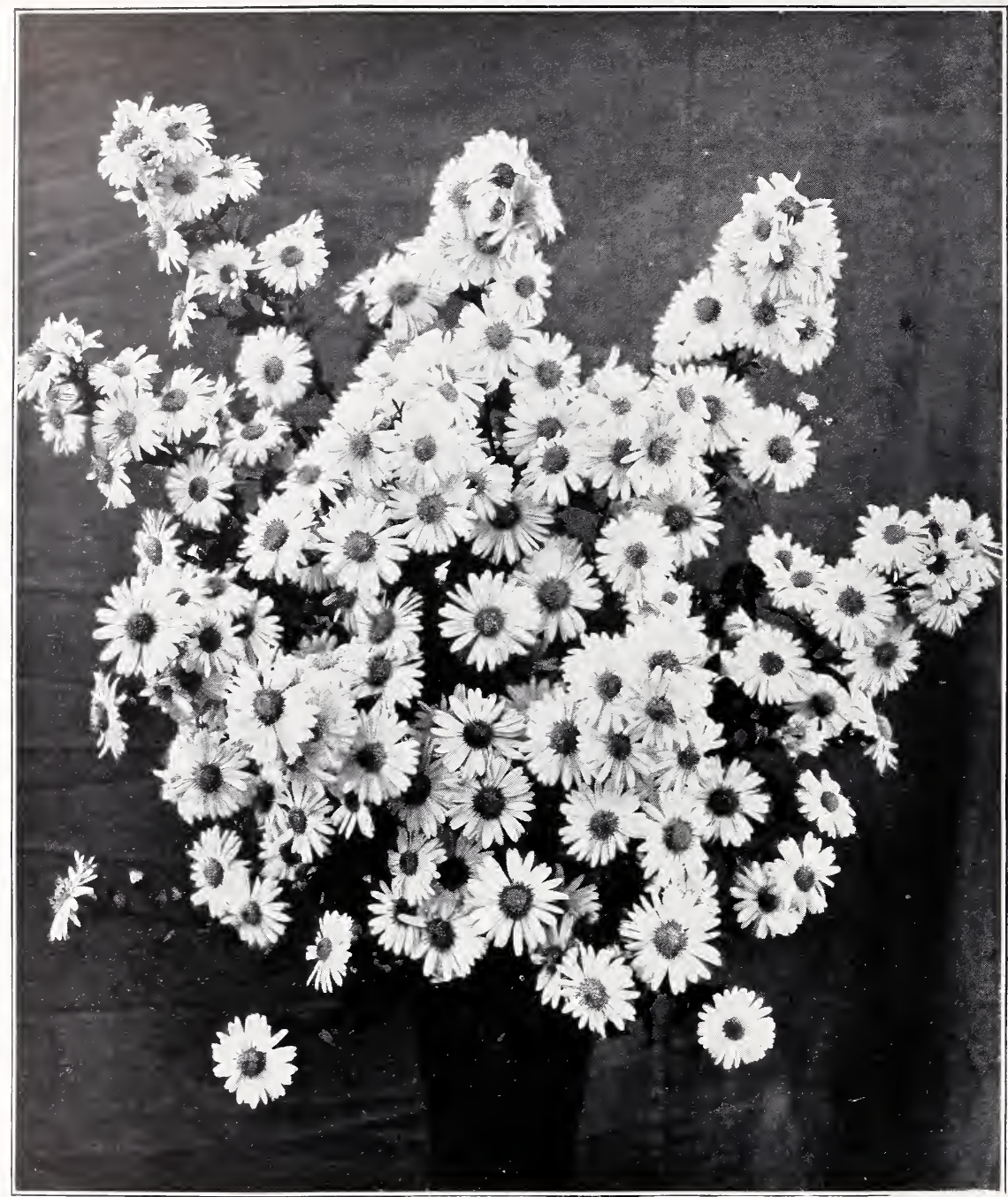

ASTER, "CLIMAX"

\section{ASTERS-PERENNIALS; MICHAELMAS DAISIES (Family: Compositae) \\ Ordinary Soil.}

Very beautiful late-flowering single daisies; they are giving a wealth of bloom during September and October, a season when most other flowers are past, and for the best effects should be planted in masses; they are hardy and grow freely in any soil, multiplying very rapidly. SPRING DELIVERY ONLY.

Novi Belgi Climax (see photo). Plants of strong, vigorous habit, over 5 feet high, fully one-half of which consists of much-branched pyramidical-shaped flower stems filled with light lavender-blue flowers, each $1 \frac{1}{4}$ inches or more in diameter; it blooms from September until the end of October. Strong roots, 25 c each; 5 for $\$ 1.00$. 
Roycroft Purple. A large, deep purple with yellow center; very attractive color and exceedingly showy; blooms in October; a rare and distinct kind. Strong plants in early spring, each $25 \mathrm{c} ; 5$ for $\$ 1.00$.

King George. New. Very large flowers in large trusses of a rich blush violet color. Grows only 2 feet high. Fine for the rockery. Strong roots, 40c each; 3 for $\$ 1.00$.

Elsa. A really grand variety; huge Hlowers that open quite double but finish semidouble; very free flowering and of graceful habit; height, $3 \frac{1}{2} \mathrm{ft}$. The color is a soft, rosy blue. Award of Merit, R. H. S. Strong roots, 40c each, 3 for $\$ 1.00$.

Barr's Pink. A lovely light mallow pink with stiff petals and a brilliant golden center, 3 to $4 \mathrm{ft}$. high. The individual flowers are $2 \frac{1}{2}$ inches in diameter, coming into bloom about mid-September, and are a mass of glowing pink in the garden. 50c each.

\section{A FEW BRIEF HINTS ON THE CULTIVATION OF MICHAELMAS DAISIES}

Mr. Ernest Ballard, of Colwall, near Malvern, the well-known raiser of many new Asters, gives the following advice on the cultivation of his favorite flower:

I cannot too strongly urge growers, if they wish to get the best results, to allow at most not more than three stems on each plant to flower; in some instances one stem is sufficient. Cut out all others and do not allow a score of stems to grow up, one stem will give more blossoms, finer flowers, and better-shaped plants. You do not want a "clump" with many stems.

lt is best to lift all the stronger-growing varieties every autumn or spring and replant only the strongest outside shoots, discarding the middle of the plant; by so doing they are kept vigorous and healthy, and free from disease.

Tying up is of great importance. Use a strong stake for each stem. This should be done early in the summer when they are one foot or two feet high, before the side sprays have developed. In this way the stakes will be hidden.

Give all the room between each plant that is possible, anything up to three feet apart. Keep a sharp look-out for slugs, especially when first planted.

Native Michaelmas Daisies are swamp plants; they are moisture lovers, therefore if possible plant in a damp situation.

They will grow almost anywhere, but prefer a stiff loam or even clay. If, however, only a hot, dry situation is available much may be done by giving the plants a spring mulching of long manure, or anything (mowing grass) that will help to retain moisture and keep the roots cool during the summer. In dry times they will benefit by a thorough soaking of water, but it is not necessary.

One of the finest Michaelmas Daisies in cultivation is seen in the variety KING GEORGE. The flowers are of large size and perfect form, while the colour is a beautiful violet blue. As this Michaelmas Daisy only attains a height of three feet, it is excellent for small gardens.

\section{ANCHUSA MYOSOTIDIFLORA}

A charming plant with the exquisite blue flowers of Forget-Me-Nots and large heart-shaped basal leaves. A clump of this beautiful plant is about a fooi high, as much across, and a more beautiful subject for the cool rock garden or the border is not easy to find. PLANTS, 50c EACH. No seeds until after harvest.

I should like to suggest to "An Amateur of Hardy Flowers" that the reason he fails with Anchusa myosotidiflora is that he plants it in ordinary, perhaps rich, garden soil. I put one or two in the herbaceous border, but quickly took them out as they were practically all leaf. Now I grow quantities in the wilder part of the rock garden. In sandy, dry, poor, very poor, soil, and there the leaves are small, the flowers stand up high above them in sheets of blue, and they last for weeks. They are universally admired. A sloping bank of them with Dielytra formosa below and Grape Hyacinths among the latter forms a charming picture.

-N. S. C.( ln Garden lllustrated). 


\section{ANEMONE-Windflower \\ ANEMONE JAPONICA (Japanese Anemone) \\ For sale only in Late Spring}

Valuable plants suitable for massing or single specimens. They grow rapidly and are profuse in bloom, gaining strength and beauty each year. The blooming period extends from September till mid-November, the large, open flowers furnishing abundant cut flowers and a brilliant field display. Cover plants in Winter. We offer strong, field-grown roots.

Alice. Large flowers of rose-pink, lilac center; excellent new variety. The best and strongest grower of all pink sorts. 3 for $75 \mathrm{c} ; \mathbf{\$ 2 . 5 0}$ per doz.

Queen Charlotte. Abundant semi-double flowers, broad and perfectly formed; "La France" pink. 2 to 3 feet. 30 c each; 3 for 75 ; $\$ 2.50$ per doz.

Whirlwind. Excellent double white flowers. 2 to 3 feet. 25c each; 3 for 60c; $\$ 2.00$ per doz.

Pulsatilla (Pasque Flower). Grows from 9 to 12 inches high and produces violet or purple flowers during April and May. An interesting plant for the rockery or well drained border. 35 c each; 3 for $\$ 1.00$.

\section{AQUILEGIA, COLUMBINE (Family: Ranunculaceae)}

Does well in the shade and loves a moist situation.

Long Spurred Hybrids (Mrs. Scott Elliott's strain). One of the best strains including all shades of blue, pink, yellow, etc. Seedling plants, per doz. 60c, 25 for $\$ 1.00$; individual clumps in two sizes, $25 \mathrm{c}$ each, $\$ 2.50$ per doz., and $40 \mathrm{c}$ each, $\$ 4.00$ per doz.; mixed colors, only, not sold to color.

Rocky Mountain Columbine. We think this is the finest of all Columbines; very long spurs of an exquisite light blue color; not a very strong grower, and rather difficult from seeds, but when once established, a gem. Plants, 25c and 40c each; seedlings, September and October delivery, $75 \mathrm{c}$ per doz. These will bloom the following year.

Owing to the early awakening of the Columbine in the spring in our mild climate, we can not ship individual clumps after April 1st, except seedlings.

\section{THE TIME TO PLANT DELPHINIUMS}

September is best; October is too late (except in milder climates), and they are apt to perish over the winter, and of course we will get the blame. Many growers prefer spring planting, just when they start into growth, and that undoubtedly is an excellent time; this means, with us along the coast, often February and always March. We are not going to send any more "CLUMPS" to the East in April; plants are entirely too large, the stalks will rot or wilt in transit and such a late planting proves often unsatisfactory. If you live in a climate that does not allow planting before April and May, we advise either to plant the clumps in September, or to buy small seedling plants, which we can send as late as May-these little seedlings will bloom the same season in September and October. Yes, Delphiniums will bloom from 4 to 6 months from seed, depending upon the strain.

Dear Sir-I do not agree with the statement in the last number of "Horticulture" that the planting of delphiniums should stop at the end of September. It is true, of course, that delphiniums are easily heaved out of the ground by the alternate thawing and freezing of winter. Nevertheless, if they are planted firmly and given adequate protection they will go through the winter safely, I find, if left until October. Indeed, I consider this a better month than September for such planting operations. -W. N. Craig, in "Horticulture." 


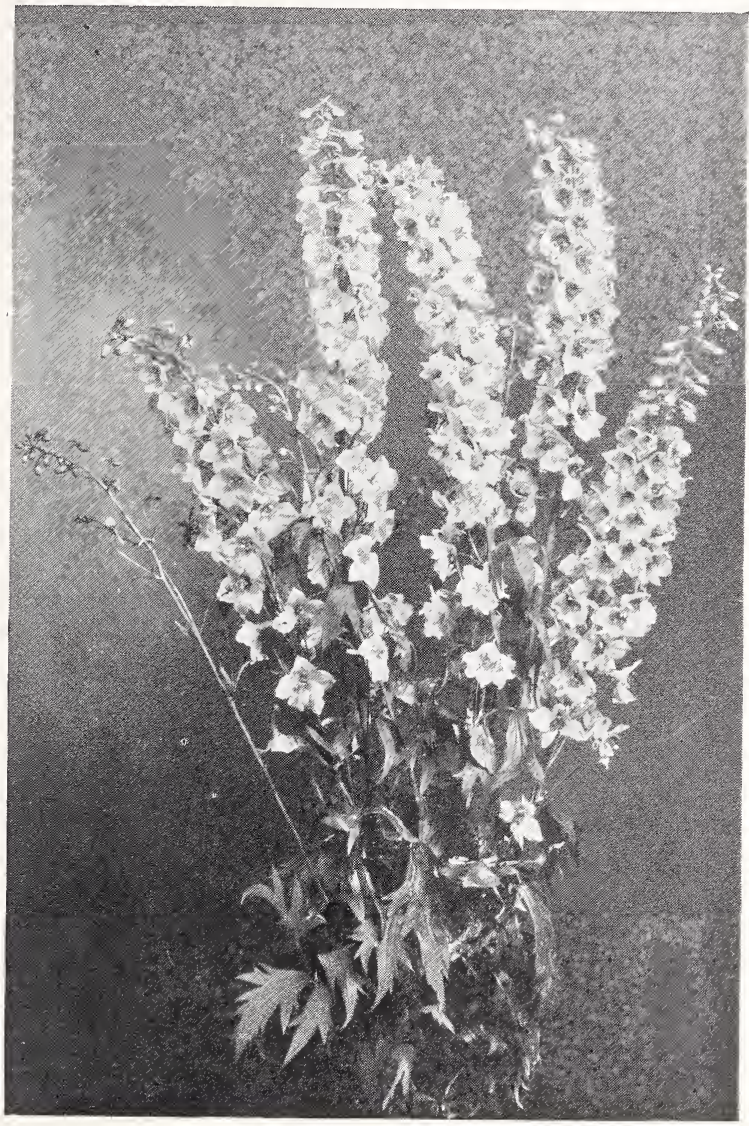

PUDOR'S “GLORY” DELPHINIUMS-I20 Days from Seeds

These magnificent Delphinium spikes, photographed in the early part of September, were grown from our choice Delphinium seeds, sown out-of-doors on April 20th. They bloomed all fall until killed by frosts in the latter part of October, producing magnificent spikes four to six feet tall. The plants themselves, of course, will survive the coldest winters, anywhere, with a little protection, or none at all.

See what a glorious Delphinium display you can have in the late fall, when your large clumps have long passed their glory, by simply sowing the seeds during March and April, and even the first part of May.

Only spring-sown seed of such perennials as Delphiniums, Lupins, Geums, Per. Flax, Scabiosa Caucasia and Siberian Wallflower, will produce their lovely flowers out of season; fall-planted seeds will bloom at the regular time in June or July. 


\section{Delphiniums}

\section{Hardy Perennial Larkspur}

\section{NO MORE TINY, OR SO-CALLED “BABY”, SEEDLINGS IN THE SPRING!}

As this size does not mature early enough to send out till May or June, when the weather often gets quite warm, resulting in heavy losses in transit, WE SHALL DISCONTINUE SENDINIG OUT SMALL SEEDLINGS IN THE SPRING. They will be only available during AUGUST, SEPTEMBER and OCTOBER, when they ship well and the loss is practically nil. These seedlings will be described and priced in our mid-summer Bulb and Seed Catalog, issued by August 1st, of which all our customers will receive a copy.

\section{SEEDLING PLANTS AND CLUMPS}

DELIVERY: FEBRUARY AND MARCH, and if our season is backward, up to April 10th-never any later. Orders coming in too late will be filled in September or fall.

PRICES: IN MIXTURE ONLY OF EITHER WREXHAM OR GLORY OF PUGET SOUND STRAINS (no named varieties and no PRIZE WINNER strain offered this spring).

We will have them in three sizes: 15 c each or $\$ 1.50$ per doz.; 25 c each or $\$ 2.50$ per doz.; and $35 \mathrm{c}$ each or $\$ 3.50$ per doz.

Not less than three of any sold.

Advanced seedlings from our glorious "PRIZE WINNER STRAIN" ready in AUGUST, SEPTEMBER and OCTOBER (NOT this spring) at $\$ 2.50, \$ 3.50$ and $\$ 5.00$ per doz. Get your order in early for this strain.

Advanced seedlings "BLACKMORE \& LANGDON" English strain from their finest named varieties and new outstanding novelties, for sale only in the fall$\$ 2.50$ and $\$ 3.50$ per doz., according to size.

Advanced seedlings from "KELWAYS" finest English named varieties and 1929 novelties, to be had only in the fall at $\$ 2.50$ and $\$ 3.50$ per doz., according to size.

How large are "ADVANCED SEEDLINGS"? Most of them have already bloomed with one stalk in our gardens; they will give you from 3 to 6 blossom stalks in your garden next season, are exceedingly cheap at the price, and really the best size to transplant, better than large clumps.

\section{LARGE CLUMP SIZE}

Many people prefer this size for immediate big effects. From our best "PRIVATE COLLECTION" of the "GLORY OF PUGET SOUND" strain, really lovely, graceful, light and pure blue shades, mostly all double; a fine assortment collected during many years' work and selection. Do not order special shades, or specify color of bee, or single or double varieties; these clumps are only to be had in assortment, at prices of $\$ 1.00$ each postpaid up to six, or $\$ 10.00$ per doz. by express, charges collect. For sale only during February and March and again in September and October.

Mr. Watkin's Samuel Wrexham Strain. Delivery same as above. Prices: 50c each up to six by mail prepaid, or $\$ 5.00$ per doz. by express, charges collect.

Extra Choice Varieties: $\$ 1.00$ and $\$ 2.50$ each.

\section{CLUMP DIVISIONS OF NAMED VARIETIES}

Pudor's Blue Bird Glory. A lovely, dainty, deep blue with double blossoms and very small bee. Per division, \$2.00.

Pudor's Glory of the Sky. A charming, most appealing light blue; like a clear, turquoise sky; fully double with small white bee. Per division clump, $\$ 2.50$. 


\section{NEW ENGLISH "NAMED" BELLADONNAS}

Bella Donna "La Martine." A few years ago we imported from England a number of this variety and we have now a sufficiently large enough stock to sell a limited amount of good, strong divisions that will bloom for you next season. The flowers are of a deep sky-blue with a white center. A very fine and lovely variety and a great bloomer. Habit of the plant is bushy, branching, about $4 \mathrm{ft}$. high. Strong divisions, $40 \mathrm{c}$ each and $\$ 4.00$ per doz. clumps.

Bella Donna Delphiniums, Cliveden Beauty and Fanny Stormonth are almost similar; we will have clumps to spare of these lovely, sky-blue varieties at $40 \mathrm{c}$ each, post paid, or $\$ 4.00$ per doz. by express.

Bella Donna Formosum. Rich, dark blue in clumps at $25 \mathrm{c}$ and $40 \mathrm{c}$ each, $\$ 2.50$ and $\$ 4.00$ per doz.

Chinese Azure Fairy and Blue Butterfly, lovely low growing hardy Delphiniums, are easily and quickly grown from seeds and can be treated as annuals, but we usually have a stock of ready-to-bloom seedlings at $50 \mathrm{c}$ and $75 \mathrm{c}$ per doz.

\section{GEUM, AVENS (Family: Rosaceae)}

Borisii. A beautiful hybrid by King Boris of Bulgaria. New and rare. Single flower of a rich orange scarlet-a rare color; in bloom continuously until after frosts; a good rock plant. 1 foot. For 2 years we have tried to grow this variety from - both imported and our own-but never a plant did we get. Strong rooted division at 75c each; not more than 1 to a customer.

Lady Stratheden. Rich golden yellow, double, a great favorite. Plants, 25c and 40c each.

Mrs. Bradshaw. 2 feet; large brilliant semi-double scarlet; splendid for cutting. Plants, $25 \mathrm{c}$ and $40 \mathrm{c}$ each.

\section{HOLLYHOCKS; ALTHAEA (Family: Malvaceae)}

Newport Pink. Double Pure Yellow. Plants 25c and 40c each. $\$ 2.50$ and $\$ 4.00$ per doz.

\section{HYPERICUM POLYPHYLLUM (St. John's Wort)}

The rock garden is not a very attractive feature during the early days of autumn. Most of the plants have long since ceased to flower. For this reason any lowgrowing plants that will thrive in elevated positions and give us flowers at the season named are sure of a good reception. One such is the charming little Hypericum polyphyllum, a native of Asia Minor.

It forms a neat cushion of pale glaucous leaves, its slender stems having a very decided prostrate habit.

The flowers, which are an inch in diameter, are produced moderately freely, the color being a rich golden-yellow.

lt flowers during May and June, and again in September, when it seems brighter and more attractive.

For clothing the top of a rock or dry wall this plant is excellent, and it will thrive in any soil. Clumps 40 c each, 3 for $\$ 1.00$.

\section{JAPANESE IRIS SEEDLINGS FROM MY CHOICEST SEED}

Ready inMay or June, $60 \mathrm{c}$ per doz.; or advanced seedlings in the fall, $15 \mathrm{c}$ and 25 c each; $\$ 1.50$ and $\$ 2.50$ per doz. The larger ones may be expected to bloom the next season; not sold to colors. 


\section{LAVANDULA (Lavender)}

Nana. Is a very fine new dwarf English introduction. Good for edging and planting between roses. $50 \mathrm{c}$ each, small size, 25c.

Vera. This is the true Sweet Lavender; grows about 18 inches high; delightfully fragrant blue flowers in July and August. 50c each, small clump 25c.

Bowles' Early. A very fine strain of early-flowering lavender, producing long spikes of flowers. $50 \mathrm{c}$ each, small clump, $25 \mathrm{c}$.

\section{LILY OF THE VALLEY}

These lovely flowers are too well known to require a description. Strong fieldgrown clumps for immediate effect, 50 c each; $\$ 5.00$ per doz. Single Pips, $\$ 4.00$ per 100 .

Either fall or very early spring planting; will succeed best in the shade or northern exposure.

\section{LINUM-PERENNIAL FLAX (Family: Linaceae)}

Sibiricum (Perennial Blue Flax). Dainty feathery foliage, slender growing hardy perennial, with light blue flowers; $2 \frac{1}{2}$ feet; lovely for the rockery or among other plants. Strong field-grown plants, 15c each; $\$ 1.50$ per doz. Larger size, 25c each, $\$ 2.50$ per doz.

Of Linum Narbonense we only sell the seeds.

\section{LUPINUS POLYPHYLLUS}

Hardy Perennial Lupines. A valuable race of new hardy perennials that will vie with the Delphinium in popularity; lovely shades of blues, purples, pinks, whites, yellows, apricots and many intermediate shades; in very cold climates it is best to treat them as annuals, sowing the seeds either in the fall in cold frames, or outside early in the spring, when they will make a fine showing during the autumn; but their real blooming season is in May and June from seeds sown the previous year. With some protection in very cold climates they will live year after year, the clumps getting larger and finer from year to year. Our large field of 3-year-old plants of the new English Hybrids: Downer's, Elliott's and Harkness Regal Strain, was such a glorious sight during the latter part of May and up to the fifteenth of June that thousands of visitors from neear and far pronounced it the most wonderful and gorgeous sight they ever beheld. All the varieties and colors were planted together, and it was a color symphony of the rarest beauty, indeed. ln growing these hardy lupins, you must bear two things in mind: Give them only little fertilizer and some lime, and when dry weathe rcomes and during their growing season, they must not suffer for water. Our field is planted in a moist, stiff clay soil, and here they grow to perfection. We have one planting in very sandy soil, and here they do as well, but do not grow as tall, not producing as fine flower stalks as on heavier, moist land. We never irrigate or sprinkle them because we can't.

These Lupins bloom with the Iris, and in a home garden wonderful color combinations can be made with these two flowers. They fade just when the Delphiniums come into bloom, but by removing the faded blossom-stalks about a foot or two from the ground, they will burst again into bloom in August, blooming until cut down by frost. Plants ship very well, both baby seedlings and large plants, but owing to the early growth, as with clumps of Delphiniums and Columbines, no plants can be sent after April 1 st. 


\section{ADVANCED LUPINE SEEDLINGS}

These have not yet bloomed; they will only partially come true to color-the rich apricots and rare yellows are especially hard to get; most of the pinks will come true with a wonderful range of pink shades; but even the rogues will be of wonderful shades: we are trying hard to eliminate all the undesirable purple and blue shades, but there are some wonderful blues, and some very desirable rich plum purples.

Mixed Seedlings in two sizes, $75 \mathrm{c}$ and $\$ 1.00$ per doz. Larger plants, 25c each. None have bloomed yet.

Clumps in Separate Colors. Owing to a very large demand the past season, we are sold short on all colors, except the "MIXED VARIETIES," and we will be unable to supply you with any pinks, blues, purples, yellows, apricots and Rosy-Morn until the fall of 1930 ; seeds only this spring.

\section{NEPATA MUSSINI (Catnip)}

An excellent plant for any position, but especially useful in the rock garden. Of dwarf, compact habit, producing masses of bloom. The soft, lavender shade of the flower and pleasing gray of the foliage, make this an attractive plant. lt thrives in dry, sandy soils, and remains in beauty over a very long period. The plant may be easily increased by division in the autumn or spring. Strong plants, 25c and 40c each; $\$ 2.50$ and $\$ 4$ per doz.

\section{RUDBECKIA (Cone Flower)}

R. Maxima. A rare and attractive variety, growing here in our garden 6 to 8 feet tall, with large glaucous green leaves and bright golden yellow flowers, 4 to 6 inches across, with a green cone an inch or more high; in profuse flower during September. Plants, 25c each; $\$ 2.50$ per doz.

\section{SCABIOSA CAUCASICA}

A very large percentage of failures with Scabiosa caucasica may be traced to late transplanting. On soils which are light, gritty, well-drained, and in situations where spring droughts are frequently trying, it is prudent to plant this Scabious during the second half of August or the first half of September. There are few gardens where it is wise to transplant Scabious in October or November, but often, when it is an item in a hardy plant border of miscellaneous character the Scabious arrives with the Heleniums, Phloxes and other plants which have no fastidious whims, and it requires no more than the average November and December conditions for the crowns and roots of the Scabious to decay in the ground.

Where soil inclines to heaviness, or the situation is low-lying and damp, it is infinitely safer to transplant in April, and, assuming the season is normal, April is better than either March or May, because the roots will be just active enough to take hold of the fresh soil without delay, and top growth will not be far enough advanced to suffer as it sometimes would be in May.

The popular belief is that a good, strong clump of any plant stands a better chance of success than a small one, but I would infinitely prefer quite a young plant of Scabiosa caucasica with one crown and a goodly number of young fibrous roots. Such plants become re-established without difficulty, whereas the big clump is generally an old one with a hard, woody root-stock and few fibrous roots. Such are the plants which become half rotten before they have been able to develop enough roots to set up a proper flow of sap.

There is no gainsaying the plants raised from seeds transplant with greatest safety, but reliance upon seedling plants frequently means that one has to be content with flowers of mediocre quality, for Scabiosa caucasica is extremely variable in form, substance and color.

Stock of first-class forms or distinct varieties is propagated by offsets or single crown divisions, and it is such plants which, transplanted in April, will yield the finest results.-A. J. Macself, in the Gardeners' Chronicle. 


\section{SCABIOSA-PINCUSHION FLOWER (Family: Dipsaceae)}

S. Caucasica. Isaac House's finest Hybrids. Hardy perennial; many new shades of lilac and deep blue; prized for cuttings; 12 to 18 inches. $35 \mathrm{c}$ each; 3 for $\$ 1.00 ; \$ 3.50$ per doz.

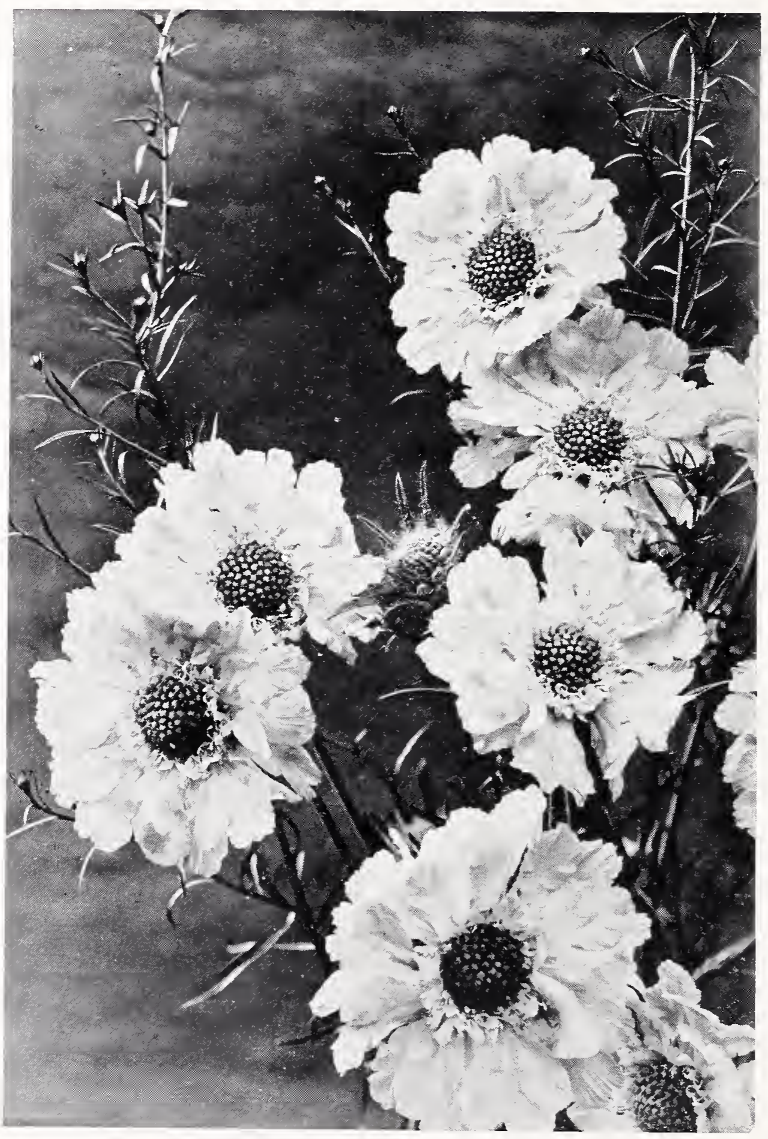

SCABIOSA CAUCASICA

The New Isaac House's Hybrids, in Many Shades of Blue.

\section{SPECIAL NOTE}

Seeds and all Unbloomed Seedlings, though offered in Separate Colors, must be accepted as from Mother plants only of the Colors indicated, with no warranty, expressed or implied, that the progeny will be constant to the parent Colors. 


\section{THERMOPSIS (False Lupine; Buffalo)}

Caroliniana. A showy, tall-growing plant, attaining a height of 3 to 4 feet, producing long spikes of yellow flowers in June and July. 50 c each; 3 for $\$ 1.25$.

\section{THYMUS (Thyme)}

The charming Mountain Thymes make a perfect, close, fragrant carpet on hot, dry, sunny banks where grass is difficult to establish; they are a sheet of blossom in June and July. Excellent for carpeting patches of Spring-flowering bulbs.

Citriodorus. The golden yellow form of the well known "Lemon Thyme." 30c each; 3 for $75 \mathrm{c}$.

Serpyllum Album. (White Mountain Thyme). Forms dense mats of dark green foliage and clouds of white flowers. 3 to 4 inches. June-July. $35 \mathrm{c}$ each; 3 for $\$ 1.00$.

Serpyllum Coccineum. Plants become completely covered with brilliant crimsonscarlet flowers. 35c each; 3 for $\$ 1.00$.

\section{TRITOMA (Red Hot Poker; Flame Flower; Torch Lily)}

Pfitzeri. The free and continuous blooming qualities of this variety have made it one of the great bedding plants. Hardy if given protection, but the most satisfactory method of wintering is to bury the roots in sand in a cool cellar. In bloom from August to October, with spikes 3 to 4 feet high, and heads of bloom of a rich orange-scarlet producing a grand effect either planted singly in the border or in masses. 40c each; 3 for $\$ 1.00$.

\section{R. VIOLAS-Violet Family-(N. O. Violaceae)}

The Viola is a very popular flower for bedding purposes; being practically hardy in character, they are easily cultivated, and when planted in bold groups or masses of distinct colors give a splendid effect, in many cases lasting throughout the entire summer. They are also suitable to harmonize with any other select bedding plants and make an excellent ground work for standard roses. To insure the best results, the dead flowers should be removed regularly.

R. Viola Sutton's Apricot. A charming and unusual apricot color. Rare. Plants, 35 c each.

R. Viola Hybrida. Jersey Gem. A lovely, most remarkable chance seedling, originated in the garden of Mr. A. T. Weston, New Jersey. The blooms, which are as large as a violet, are slightly scented, and of a pure violet color, born on stiff stems 6 inches long. Jersey Gem is said to be a more vigorous than the true Viola Cornuta, with better foliage and larger and better flowers. It is easy to grow in a rich soil, in an open situation. A large bed containing some 120 plants in the originator's garden was never without flowers throughout July and August, and over 1000 blooms were picked each week. This plant is a gem indeed. Strong plants, $25 \mathrm{c}$ and $35 \mathrm{c}$ each; $\$ 2.50$ per doz. Small divisions for the border, $\$ 15.00$ per 100 . Ours came direct from the originator; they are not seedlings, which vary in color and habit. Be sure and get the true and original JERSEY GEM.

Viola Hybrida. Jersey Jewel. New. Finer and larger than J. Gem. Original plants (not seed!ings), 50c each.

\section{VERONICA}

Veronica Rupestris (Creeping Speedwell). Rock or border plant. A prostrate creeping plant with almost evergreen foliage, and myriads of gentian blue flowers in spring. Height 2 inches. Hardy and a rapid grower, but does not become a weed. Prefers sun or semi-shade.. Excellent for borders of garden beds, steep terraces, paved walks, rockeries, etc. $25 \mathrm{c}$ and $40 \mathrm{c}$ each; $\$ 2.50$ per doz. 


\section{SPECIAL NOTICE!}

All Tiny Seedlings are sent by Post, carefully packed between layers of fine moss, and at the prices quoted they are package and postage free. Some people prefer to have them sent by express, thinking the package will get more air, but the package, of course, is very small.

Owners' Risk. All plants are forwarded at Owners' Risk. The Post Office Departments accepts no responsibility for damage or delay, and I certainly can not, and immediately the plants are placed in the mails or in the express office, they are at the sole risk of the consignee or purchaser.

\section{OTHER PUBLICATIONS}

“MISSOURI BOTANICAL GARDEN BULLETIN," entitled "GROWING PLANTS FROM SEEDS," handsomely illustrated with 29 photographs, showing the whole process of sowing seeds to the transplanting of the seedlings. It is by far the best bulletin on the subject we have ever seen. Through the courtesy of the Botanical Garden we were given special permission to reprint this bulletin. Price $\mathbf{1 5}$ c. Ask us for it.

Please send stamps or coin, or include amount with your order, (except the U. S. Departmental bulletins; write for these direct to Washington, D. C.)

\section{DELPHINIUMS AND HOW TO EXCEL WITH THEM}

An interesting and practical 20-page illustrated booklet on the propagation, cultivation and exhibition of these popular and beautiful flowers. It was written by Mr. A. J. Macself, the Hon. Secretary of the National Hardy Plant Society of London, England, an authority on Delphiniums. The price is 25 cents, and no refund. We have this for sale.

\section{A MOST EXCELLENT 90-PAGE PLANT BULLETIN}

Handsomely illustrated. Write to Washington, D. C., U. S. Department of Agriculture, for Bulletin No. 1381 (free) entitled "Herbaceous Perennials." All your troubles and questions are answered and solved in this most excellent publication. Don't ask us for this bulletin.

\section{INSECT ENEMIES OF THE FLOWER GARDEN}

Kill them dead. U. S. Department of Agriculture, Farmer's Bulletin No. 1495 will tell you how. Send $15 \mathrm{c}$ in coin (not stamps) to the Superintendent of Documents, Government Printing Office, Washington, D. C. Do not send to us for it 


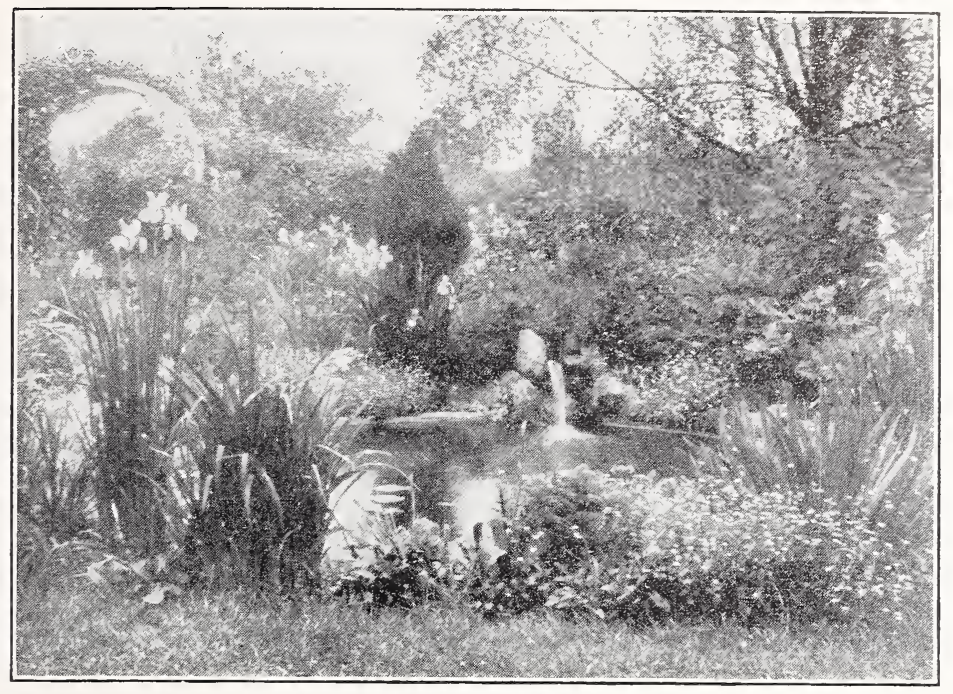

CREATE SOMETHING LOVELY.

BUILD A POOL AND PLANT IRIS AROUND ITS MARGINS.

\section{THE BEST SEASON FOR TRANSPLANTING IRISES}

W. R. Dykes was long one of the most prominent lris growers of England and the author of several books which are standard the world over. He was killed in an accident and his widow has continued his gardens and his collection, which was very large. In a recent issue of "The Garden" Mrs. Dykes discusses the much mooted question of the best time to transplant Irises. In the couse of her article she says:

If lrises are only to be moved from one place to another in the garden and the plants not kept out of the ground for more than a few minutes one can proceed to do this immediately after the plants have flowered, or even when the plants are still in flower. If carefully handled the young roots will suffer no damage, and soon push out again into new soil. If, however, plants have to be kept out of the ground for some time, as in the case of sending out plants by post, etc., it is best to wait till August, or even September. By this time the root fibres will be mature and less liable to injury through exposure or rough treatment.

July is not a good month for moving Bearded Irises, as most of these form their embryo buds for the following year in this month, and, if disturbed, they are likely to be checked and will not flower the following year. Plants which are moved quickly immediately after flowering or during the months of August and September, but not later, usually flower freely the following year. My husband moved all his Irises from the John lnnes Horticultural lnstitute at Merton to this garden during the first fortnight in September. There were thousands of plants, and some had to be left unplanted for several days, but in spite of this more than two-thirds of them flowered the following year.

Last year 1 transplanted a good many lrises in September and they flowered exceptionally well this year. Among them were Amber, Aphrodite, and Moonlight, and I have never seen these flower more freely.

Irises need to be transplanted every third year if they are to do really well, as they are shallow-rooted and increase very rapidly, but when once planted they need very little attention beyond occasional hand-weeding and loosening of the surface soil. In the Autumn, when the leaves begin to wither, these should be removed from time to time when they come off easily, but on no account should the leaves be cut short in order to make them look tidy. 


\section{DUTCH, ENGLISH AND SPANISH IRIS BULBS}

These can only be planted during August and September, up to October 15thnot later-the earlier the better, as the Spanish lris bulbs make a leaf growth in the late fall. With protection, these can be raised anywhere. A customer in Toronto having assured us that he winters them successfully in that cold country by mulching the beds heavily. For description and prices of these bulbs, see our lris Catalog or our Special Summer Seed and Bulb Booklet.

\section{PERENNIALS IN THE SOUTH}

The long, hot, and dry summers in the South are severe for perennials, and for several years all my efforts to grow them were a complete failure. I sowed the seed as the directions advised me to do-in the fall. Very few of them germinated, and those that did, did not live. I planted them the next year in May. These came up nicely but did not live long. In Mississippe we had an unusually hot, dry June that year, and there was no suitable weather for transplanting.

Next, 1 tried planting them in boxes in the house in midsummer. They germinated well, but the plants were spindling, and l felt that they could not bear transplanting. l was almost ready to give up and buy my plants. But as plants are rather expensive, l determined to make one more effort.

Last year about the middle of February l sowed the seeds in a hotbed, just as l do my tender annuals, delphiniums, columbines, digitalis, platycodons, hardy pinks, and hollyhocks. 1 kept them well watered, and they came up nicely. 1 gradually exposed them to the air. l found that they were hardier than the annuals and could stand more exposure.

l had two rows well prepared in my garden, and as soon as they were large enough, 1 transplanted them to these rows. This was about the first of April, and all danger of frost was over. All of them were not large enough, but I reset the better plants to give the remainder a chance to grow.

I kept them well cultivated all summer. At the approach of very hot and dry weather, l mulched in the middle of the rows, almost up to the plants, with straw and leaves. This helped to retain the moisture in the ground, and the dry weather did not seem to hurt them. Several of them bloomed, and all of them are large, sturdy plants and ready to be set out in their permanent places.

1 am very much delighted with my success, and 1 shall plant some other varieties this spring. Now 1 think 1 can be successful in growing many kinds of perennials. -Mrs. J. G. Nelson, in Better Homes and Gardens.

\section{COLORED SLIDES FOR GARDEN CLUB MEETINGS}

Over fifty Garden Clubs throughout the States showed our colored Delphinium and flower slides last year; there are some 35 of them in a set, including a little talk on the cultivation of Delphiniums, thrown on the screen and read aloud by the operator; there is also other reading matter, the whole making it a sort of an illustrated lecture. Time required for showing, about 30 to 45 minutes. We have three sets going all the time, and it is well to make application three to four weeks ahead of your meeting. Each club must pay the transportation charges of the slides to the next place, which average about a dollar each way-nearby points much less. They must be most promptly returned.

Vincennes, lndiana, October 12, 1929

Pudor's, lnc.

Puyallup, Washington

Dear Sirs:

Your slides were shown last night in our club house to a most interested group of Garden enthusiasts. The pictures were lovely and very inspiring. We grow delphiniums in this part of the country but l have never seen such beautiful specimens as you show. 


\section{For Brighter Autumn Gardens Why Not Dahlias?}

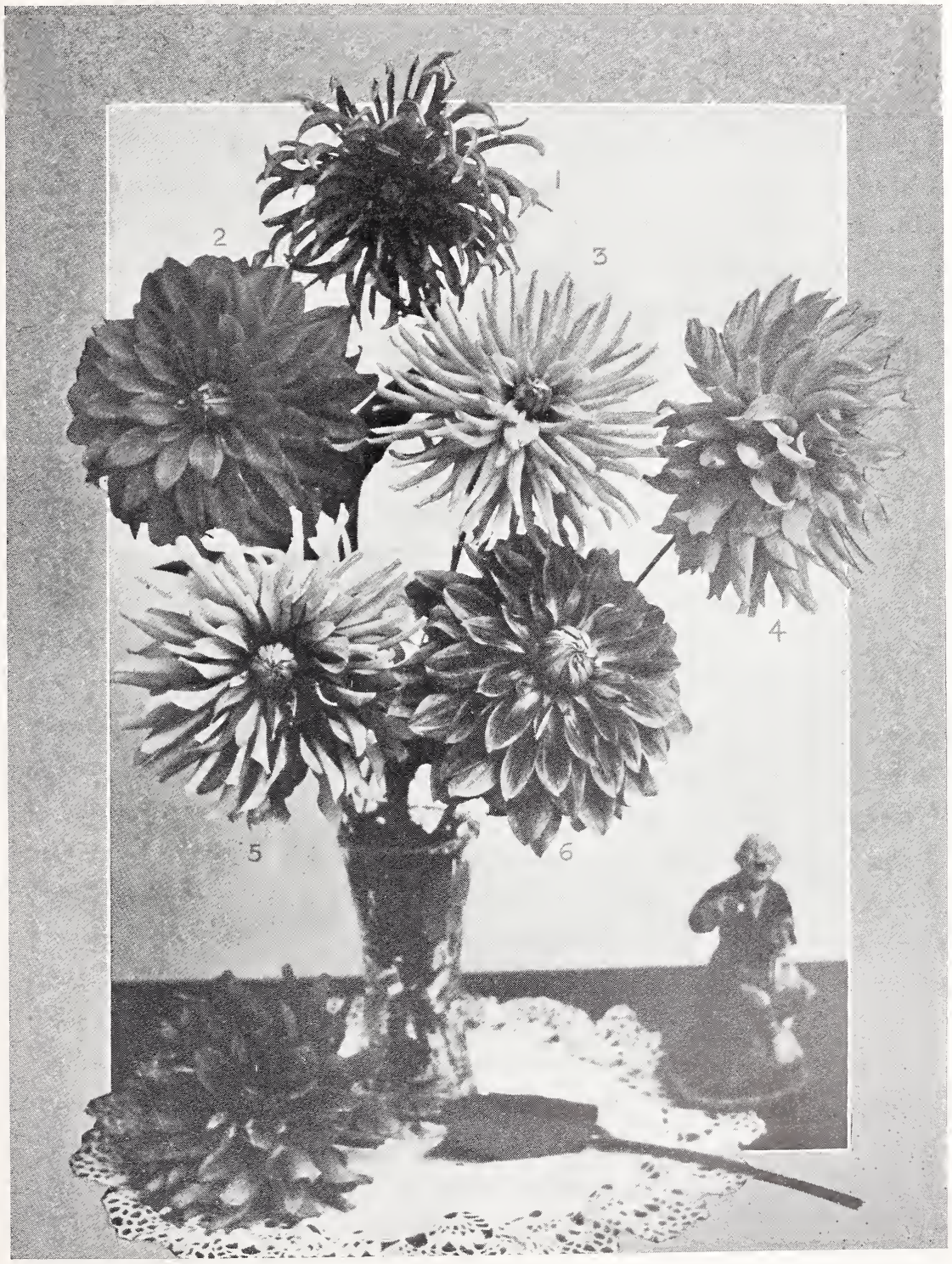

No. I Cactus variety (Rheinischer Frohsinn), No. 2 Decorative variety (SequoiaGigantea), No. 3 Cactus variety (Mrs. Edna Spencer), No. 4 Hybrid Cactus (Vivian Lanter), No. 5 Hybrid Cactus variety (Mariposa) No. 6 Decorative (Champagne). 


\section{DAHLIAS OF QUALITY AND DISTINCTION}

HOW TO PLANT. Tubers should be planted in trenches or holes six inches deep, laid flat down (not on end) and covered with earth not over two inches in depth, filling in as the plant develops. Do not plant the roots in or over any quantity of compost or hot manure. The rows should be from four to five feet apart and the plants in the row from two to three feet apart, or from six to ten square feet should be allowed for each plant. A novel way to plant is to place your stakes $4 \times 5$ feet apart, and plant a tuber or plant on each side of the stake giving room to walk between and care for your plants, and also get as many in a given area as if planted twice as close. Different varieties will not mix by growing them together. Also should one plant fail there will be no blank places.

CULTIVATION. By cultivating at least once a week, and as soon after a rain as the ground can be worked, the weeds will be held in check and a soil mulsh formed which will conserve the moisture and lessen the need of irrigation.

As the plant develops and the feed roots come toward the surface, the ground should be worked rather shallow around the hill for the radius of at least a foot, still work the balance of the ground rather deep, and bring fresh soil to plant at each cultivation, giving the plant a new supply of food and protecting the surface roots from the heat of the sun. Have the hills mounded five or more inches by the middle of September. This will help support the stalks.

\section{PUDOR'S DAHLIAS OF REAL MERIT THE BEST OLD AND NEW}

Cac. stands for the cactus variety. H. C. for Hybrid Cactus. Dec. for Decorative. Sh. stands for the popular show variety.

Alice Whittier (H. C.) One of the finest primrose yellow Hybrid Cactus, 5 to 6 in ches deep and fully 9 inches across, on long erect stems. Plants, 6 to

7 feet tall. Awarded Certificate of Merit by the A. D. S.........................\$1.50

Ballet Girl (Boston). Beautiful flowers of immense size; color, orange tipped white, some flowers pure orange, with other variations on same bush............

Bob Pluese (H. C.) Dark velvety crimson at base to half the length of petals, balance tipped pure white, making a very showy flower. Blooms are large and stems are strong and upright. Keeps well when cut and plants bloom profusely. A prize winner many times.

Champagne (Dec.) Not only is this dahlia wonderful for its size and rigid stem, but its distinct coloring, unique form and freedom of flowering make it very popular. Color, golden champagne with chamois shadings. A great favorite.

garette (Boston). Creamy white, heavily edged orange with color variations. Some flowers come all orange red. Petals are long and narrow, inclined to roll. Blooms large, on excellent stems, and of good substance. Good for cutting.

Daddy Butler (H. C.) A rosy carmine or tyrian rose, the reverse of petals a lighter tint. Has splendid stems; a very profuse bloomer, and a fine cut flower which keeps extra well.

Dictator (Dec.) Soft lavender rose, suffused with fawn; very large, fluffy

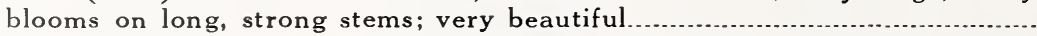

Dorothy Castle (Dec.) A huge bloom on perfect stems. Color, golden cream, edge of petals have a line of apricot, something new in color and very beautiful. Blooms early and profusely.

dith Carter (Cac.) Light yellow, tipped heavily with bright carmine; very erect habit and stems. An old variety but a fine cut flower............................

Elite Glory (Dec.) One of the newer eastern varieties that has proved to be a wonderful prize winner. Color is a radiant bright red; one of the largest dahlias we have ever grown; stems are very strong and upright. Always attracts attention in the garden or on exhibit. 
F. W. Fellows (Cac.) Flowers of phenomenal size, composed of numerous long narrow petals of a lively orange scarlet. A good exhibition and commercial variety

Golden Emblem (Dec.) A clear golden yellow of large size. Very graceful formation and high centers, the petals are long and wavy, of good substance, keeping well when cut; stems are long and strong and plants bloom profusely. An attractive flower in the garden or on exhibit.

Golden Opportunity (Sh.) Large, deep rich yellow; very strong, rigid stems

Golden West (H. C.) One of the best varieties for cut flowers and is a good keeper; color clear primrose yellow, blooms held erect on good stems

Jean Chazot (H. C.) A very beautiful French dahlia; color autumn shades of golden bronze suffused with nasturtium red; splendid stems; profuse blooming and good cut flower.

Jersey's Beauty (Dec.) One of the most beautiful true pink dahlias we have ever grown; a clear pink, large, of perfect form on long, erect stem; has won many gold medals and prizes, and we heartily recommend it.

Kalif (H. C.) Color, rich strawberry red, or carmine. The mammoth flowers are borne in great profusion. An old favorite and a good cut flower.

Maid Marion (H. C.) New. A very large full flower of a beautiful shade of rose pink; petals curl and twist forming a graceful bloom; stems are good and it blooms profusely. A new dahlia that will be a great favorite.

Mariposa (H. C.) A gigantic flower of great depth, perfect form with incurved petals. A beautiful pink shading darker at center with a violet suffusion which adds to the effect. A sturdy grower and a great favorite....

Marmion (Dec.) One of the very largest dahlias. Color is pure golden yellow with bronze suffusion on reverse of petals and the deeper bronzy tone on the high, full center, and an outline of same shade around each petal enhances the beauty of the flower. Petals are long and wavy and eliminate any hint of coarseness. The long, cane-like stems hold the huge blooms erect. Scored 90 in Northwest Trial Garden. One of the big prize winners

Miss California (Pelicano) (Dec.) Won the Santa Barbara Trophy in 1926. Blooms are 6 to 9 inches across held well above the foliage on strong, erect stems. Color described as an oriental fuchsia. A fine early bloomer good for commercial or exhibition uses..

Mrs. Carl Salbach (Dec.) Although not as deep as Jersey's Beauty, this dahlia is very similar in petal formation, stem and keeping qualities, all of which are ideal. Color: lilac rose shading to white at base of petals, giving it a general tone of soft rose...

Mrs. Edna Spencer (Cac.) A beautiful shade of orchid lavender and white; flowers are large and are held well above the foliage on long strong stems. Exceptionally free bloomer, and keeps extra well when cut.

Mrs. W. E. Estes (H. C.) Large pure white.

Mrs. Eleanor Martin (Dec.) One of the largest dahlias grown; color is a blending of rose and rich mulberry; an unusual color and a very wonderful dahlia; stems are strong an dupright. One of the favorites in the garden or exhibits

Patrick O'Mara (Dec.) The color is an unusually soft and pleasing shade of orange-buff. The flowers are borne on long, strong stems held rigidly erect. One of the most lasting cut flower dahlias, 5 to 6 inches across.

Pride of California (Dec.) A large crimson red, with full dark center on good stems. Fine for garden and exhibition; an excellent cut flower.

Rheinischer Frohsinn (Cac.) Not a new dahlia, but a very popular one with our customers. Color is white at base of petals, quickly blending to bright carmine rose. Petals incurved. Stems good, and it is free blooming.......

Roman Eagle (Fisher \& Masson). This popular 1926 introduction is an uncommon autumn shade decorative of a brilliant burnished copper. Scored 89 at the D. S. of N. J. Trial Grounds. A real winner. 
Sequoia Gigantea (Dec.) A large, deep yellow decorative, noted for its vigor; strong stems

Shudow's Lavender (Boston). Silvery lavender with white shadings, of beautiful formation. Plants are tall and robust, producing immense flowers on long stems. A general favorite.

Uncle Tom (Reed-Adams) (Dec.) The deepest garnet dahlia that we have ever seen, nearly black. Rich and artistic with petals like the very finest velvet. Flowers are very large, held erect on long stiff stems. A good keeper and a color needed to finish the dahlia garden

Vivian Lanter (H. C.) Very large, lavender pink. Very free blooming, and stems are long, strong and upright. A fine cut flower and good keeper....

Time was when most gardeners believed that the first of June was quite early enough to plant dahlia tubers. As a result, many varieties did not come into flower until almost September, and the display would be cut off by frost at its very height.

But costoms change. Today, in an average season and where a well drained, fully sunlit site is used, dahlias can be planted early in May. Their growth may not be so rapid as later on, but by the time really warm weather comes they will have gained a big lead over their June-planted brothers.

\section{INSTRUCTIONS FOR PLANTING DAHLIA SEED}

Plant dahlia seed in shallow boxes which have been filled three-quarters full of good soil. Sow the seed on top and cover half an inch with light soil. Seed may be started indoors, in a hot house or in frostless belts, outdoors.

Water well and keep moist while the young plants are growing. Some of the seeds will sprout in a week or ten days, others require five or six weeks.

When the plants are four or five inches tall and all danger of frost is over they should be transplanted to the open ground. These may be planted in single rows or in double rows, alternating positions, the plants in either case being at least $1 \frac{1}{2}$ feet apart. Allow two to three feet between the rows.

Practically all will make large plants that will produce a profusion of blooms the first year. They will make small clumps of tubers which should be lifted after the plants are cut down by frost. Store the clumps for the winter in a dry, frostproof, ventilated cellar.

\section{DAHLIA SEEDS}

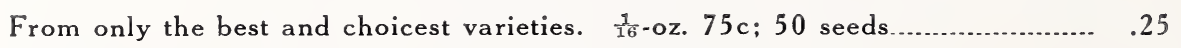

Cactus. From finest named. Mixed, $\frac{1}{16}$-oz., \$1.00; per pkt. 50

SEEDS NEW BEDDING DAHLIAS COLTNESS GEM AND HYBRIDS

Offered on page 5 . 


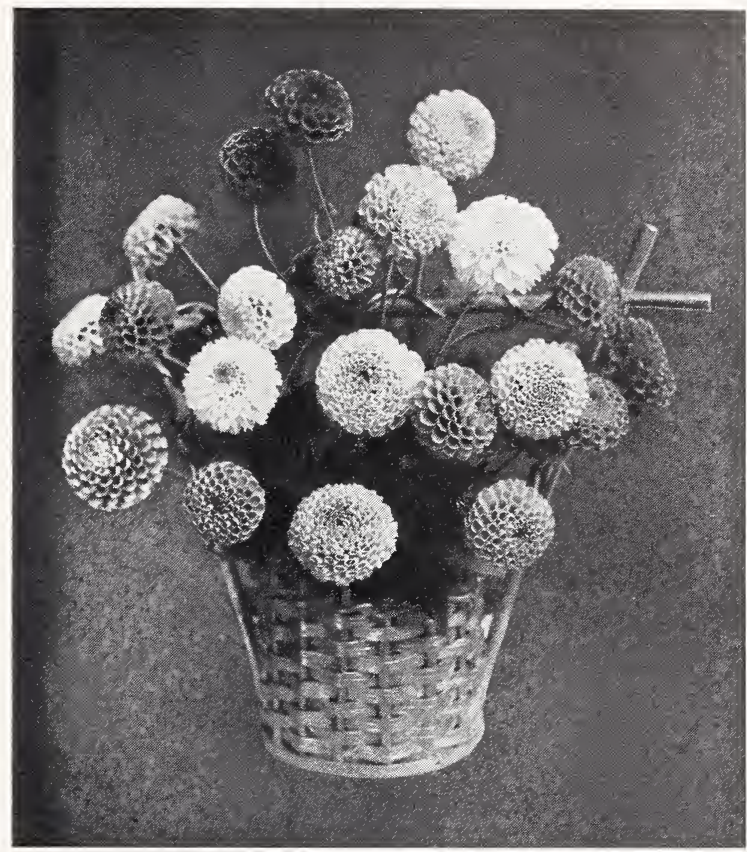

A BASKET OF POMPON DAHLIAS

Aimee. A lovely small bronze

Amber Queen. Golden amber and orange.

Bronze Beauty. Beautiful golden apricot; a free bloomer good for cutting, as all pompoms are

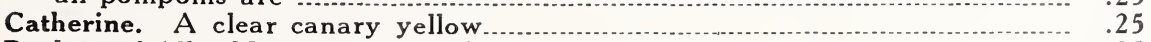

Darkest of All. Maroon, very dark

Dee Dee. Very small. Pale lilac, fine for exhibition $\quad .50$

Elizabeth. New, golden yellow edged brownish red..........

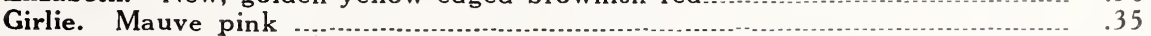

Joe Fette. A splendid pure white.........

Little David. New small orange scarlet.........

Rosea. A rosy lavender; a perfect flower

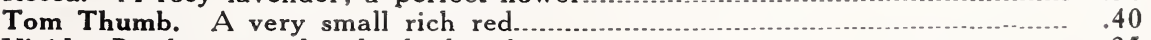

Vivid. Brightest scarlet; bush dwarf

COLLECTION: The above 13 best POMPONS for $\$ 4.00$. Regular list price $\$ 4.95$. 


\section{FERTILIZERS}

\section{NATURE SOIL IMPROVER}

for Vegetable Growers, Horticulturists, Home Gardens, Nurserymen, Florists.

\section{IMPORTED GRANULATED} PEAT MOSS

A few of the many purposes for which which Peat Moss is used:

Fertilizer Carrier, Mulching, Cold Frames, Lawns, Improving Soils, Propagating, Cuttings, Landscape Work, Benches (Greenhouse), Golf Courses, Packing, Storing Bulbs, Potting, Layering, Seed Beds.

Peat Moss improves the physical structure of the soil. It absorbs ten times its weight in water, or more, conserving it, releasing it for the plants in periods of drought.

Peat Moss makes soils favorable to beneficial soil bacteria, necessary to good vegetative growth. Plants consume humus and so do the bacteria in their operation of transforming air nitrogen into valuable plant food. Peat Moss tends to increase the humus content of the soil.

Peat Moss consists chiefly of decomposed vegetable or organic matter. It is free from weed seeds and detrimental fungi. It is produced from highlevel moorland, consisting chiefly of sphagnum moss of high quality, light in color and weight. It is light and has superior moisture absorbing and retaining qualities.

Peat Moss is clean, odorless, easily stored and handled. It promotes root development, resulting in strong, robust plants.

Sxज seed sown in so:l mixed with Peat Moss germinates more quickly than seeds in soil alone.

Peat Moss is valuable for use on greenhouse benches, in hotbeds and coldframes, in potting and bench soil, as a soil improver in garden and field, for propagating and as a mulch in the flower and vegetable garden, around trees, shrubs and hedges. lt is valuable for use on the lawn.

Peat Moss is packed in bales of standard size and bulk, with minimum moisture content. The material in a bale will cover 340 square feet one inch deep.

ln making new lawns, apply from three to six inches of Peat Moss and work it into the so:l. An even ger- mination of the grass seed will be obtained and a thick turf will soon clevelop.

Price per bale, $\$ 3.25$, f. o. b. Seattle or Puyallup.

Average weight per bale, $175 \mathrm{lbs}$.

In less quantities, $4 c$ per lb., f. o. b.

If you want a fine green lawn or an abundance of the best flowers, feed them with

\section{PULVERIZED DRY SHEEP GUANO}

Clean and convenient to handle.

$A$ cheap and efficient fertilizer.

Pulverized Sheep Guano has no rival.

This we guarantee to contain plant food as follows:

Nitrogen 1.84. As Ammonia..... 2.25

Water Soluble Potash K-2O ......... 3.00

Total Phosphoric Acid................. 1.25

Available Phosphoric Acid

Prices: 10 lbs., 30c; 25 lbs., 60c;

50 lbs., $\$ 1.00 ; 100$ lbs., $\$ 1.50$

Per ton, \$25.00.

These prices are f. o. b. Puyallup or Seattle.

\section{How Do You Buy Your Bone Meal?}

For immediate and complete assimilation by the roots of your flowers, fruit, and vegetable crops, you need a really pure bone meal; one guaranteed to contain no residue or added matter of any kind. Carsten's 100\% pure bone is rich in phosphoric acid, $(22 \%)$ phosphate, nitrogen, (3\%) and lime; has all the constituents of a perfectly natural fertilizer, and no waste or slowly disintegrating matter. Unequalled for all horticultural purposes.

Prices: $\$ 50$ per ton; $100-$ lb. sack, $\$ 3$; per lb. (not less than 10 lbs. sold), 4c. All prices less carriage.

\section{WASHINGTON PURE GYPSUM: SUPERIOR TO LIME.}

For Your Irises and Delphiniums.

Prices: Per ton, $\$ 18 ; 100$-lb. sack, $\$ 1$.

F. O. B. Seattle or Puyallup.

Parcel Post Maximum Wt.: $\mathbb{1}$

Not more than 80 lbs. in first three zones, and 50 lbs. in others. 


\section{A SPRAY CHART FOR THE GARDEN (From The Canadian Horticulturist)}

Before one can intelligently combat the insect and fungus pests of the garden, he must have a fairly accurate knowledge of both the nature of the pest and the properties of the materials recommended for their control. It is not the purpose of this chart to go exhaustively into the question of pest control but rather to set for information which will be of assistance to the gardener in keeping his crops free from insects and fungus diseases.

Remedies for insects are determined largely by the nature and habits of the insect to be controlled. In the case of those forms which eat the leaves, the usual method of control is to cover the plant with some material which will be harmless to the plant itself, but which will kill the insect when taken into its body. Most common of all materials used for this purpose is arsenic in its various forms.

\section{POISONS FOR BITING INSECTS}

Paris Green: This is one form of arsenic. It may be used either as a liquid spray or as a dry dust. When prepared as a liquid, use $\frac{1}{2}$-ounce to five gallons of water. lnclude in the mixture a couple of handfuls of fresh hydrated lime to prevent burning of the foliage. When used dry, mix $\frac{1}{4}$-pound of the chemical with five pounds land plaster or hydrated lime.

Arsenate of Lead: This material, while not so rapid in its action as paris green, is preferred by many because it adheres to the leaves much more firmly and causes no burning of the foliage. Use it at the rate of one ounce to slightly more than a gallon of water. For use as a dust, mix one part of the poison with ten parts of hydrated lime.

\section{SPECIAL CASES}

These arsenical poisons are effective against such insects as the green cabbage worm, the potato beetle, budworms of different kinds, tent caterpillars, leaf tyers, tussock moths, tomato worms, rose slugs, saw flies, rose chafers, etc. Insects of this type which require special treatments are cut worms and grasshoppers. For the former, an effective poisoned bait may be made by mixing one part of white arsenic or paris green, with 20 parts of bran. This should be moistened with molasses diluted with four parts of water. The mixture should be made in small quantities since it is only effective when fresh. It should be applied about sundown. Scatter it lightly along the rows of newly set plants or emerging seedlings. In the case of grasshoppers, the molasses may be omitted from the mixture and a little salt added. The bait should be scattered freely along the outer edges of the garden.

Caution should be observed in the use of poisoned baits. Do not use them where chickens, cattle or other animals are liable to get at them as they are just as deadly to animals as to the insects.

\section{POISONS FOR SUCKING INSECTS}

Insects which come under this class are quite different from the leaf-eating forms. These types do not eat the foliage but puncture the tissues and suck the juices from the plant. Consequently it is of no avail to spread poison on the leaves in order to kill these pests.

Contact poisons are those which kill by coming in contact with the insects body must be resorted to in order to control these insects.

Nicotine Sulphate: This is a concentrated extract of tobacco. It is prepared and put on the market in different forms by various manufacturers. Directions for use are printed on the containers, and if these are followed carefully, good results should follow.

Tobacco dust is sometimes used as an insecticide. It is of uncertain strength, however, and it is rather more effective as a repellant than as a killing agent.

Kerosene Emulsion: For many years this has been used as an effective remedy against soft bodied sucking insects. A stock solution is made from one gallon of coal oil, half a gallon of rain water and a quarter pound of laundry soap. The soap should be cut into fine shavings and dissolved in the heated water. The soap solution should then be removed from the fire and the coal oil added and the whole mixture churned violently for about five minutes until a thick,creamy emulsion is formed. On cooling, the mixture thickens into a stiff jelly which should be diluted 
with nine times its volume of warm water before using. Aphids are readily controlled by the use of this material.

Soap Washes: A fairly satisfactory remedy for many sucking insects is made by dissolving half a pound of laundry soap or better, fish oil or whale oil soap in three gallons of boiling water. Such preparations should only be used on plants with hardy foliage or if used on other plants, should be washed off again a few hours after applying.

Pyrethrum Powder: A brownish powder, derived from the blossoms of the pyrethrum plant. It may be used either as a dust, diluted with cheap flour, hydrated lime or some similar powder or as a liquid at the rate of two ounces to three gallons of water. This will kill insects as soon as it touches them, but has also the advantage of being non-poisonous to humans. Consequently it may be used with perfect safety on plants which are to be eaten shortly after the spray is applied. It is a valuable remedy for green worms on cauliflowers and cabbages after the heads have formed.

Corrosive Sublimate: A highly poisonous material which is sometimes used as a killing agent against root maggots. It should be prepared in a wooden or earthenware vessel, never in a metal one, at the rate of one ounce to ten gallons of water. Dissolve the poison in a little hot water then dilute to the required strength as it dissolves very slowly in cold water. For use against maggots which attack the roots of cabbages, cauliflowers and kindred plants, it should be applied at the rate of about half a cupful per plant, just after the first signs of egg laying have been observed. A second application about ten days after the first is worthwhile as a means of killing late laid eggs and any maggots which escaped the first dose. Great care must be observed in the use of this material since it is very poisonous and quite fatal to humans and animals even in small doses.

Other Insecticides: There are many other insecticides to be found on the market under different names. The majority of these will give very satisfactory results if the directions are followed carefully. They are usually more expensive than the home-made remedies, but involve less trouble and for this reason are preferred by many people.

\section{FUNGUS DISEASE REMEDIES}

Garden plants are subject to attacks from a number of fungus pests which may cause considerable damage if remedial measures are not taken promptly. Many of these troubles gain entrance through the leaves and the disease is confined to a large extent in this part of the plant. Fungus diseases spread by means of tiny spores which float through the air, lodge on the plant and if conditions are favorable germinate and begin to grow on the plant, bringing about a diseased condition. Since there is no way of preventing the spores from lighting on the leaves, the only alternative is to prevent their growth if possible. This may be done by covering leaf surfaces with a protective coating that will cause the death of any spores which happen to light there. Sulphur and copper compounds have long been recognized as effective remedies against fungus diseases. There are many forms in which these materials are used, but only the more common ones will be mentioned here.

Bordeaux Mixture: This is a standard remedy for fungus troubles which is made of copper sulphate and lime. The copper is the active ingredient. It can be made by dissolving three pounds of copper sulphate or bluestone in water, mixing six pounds of hydrated lime with water; diluting each with about 20 gallons of water and then mixing them. The result will be a barrelful of Bordeaux Mixture ready for spraying. For those who do not care to go to the trouble of making their own solution, ready-made mixtures are available in the market.

Bordeaux can be used with safety on practically all types of foliage. If any tendency toward burning of the leaves is noticed, increase the proportion of lime in the mixture. In order to give good results, the mixture must be applied as a fine spray so that it will cover every part of the plant. Rain will wash the Bordeaux off but on no account should spraying be deferred until after the rain, as it is during the time when the air is filled with moisture that infection takes place most readily.

Bordeaux can also be used as a dry dust in which form it is placed on the market by various manufacturers.

Ammoniacal Copper Carbonate: This is another fungicide in which copper is the active ingredient. It has an advantage over Bordeaux in that it does not dis- 
color foliage. One ounce of the copper carbonate mixed with water to make a paste along with three pints of strong ammonia diluted with water, when mixed together and diluted with 25 gallons of water will make a satisfactory fungicide which may be used in place of Bordeaux.

Lime Sulphur: A compound of sulphur and lime which has strong fungicidal properties. It is best to buy the concentrated solution from dealers and dilute according to directions.

Sulphur Dust: Finely ground sulphur makes a valuable remedy for mildews and other fungus troubles. When nine parts of fine sulphur are thoroughly mixed with one part of lead arsenate, the resulting mixture will adhere to the leaves much better than sulphur alone, and will have the addition advantage of controlling leaf eating insects.

Mixtures: It is often desireble to use a spray which will control both insects and fungus troubles. This is particularly true in the case of fruit crops. Where it is desired to combine such fungicides as Bordeaux or lime sulphur with an arsenical poison, the arsenical should be added in the same proportions os if used with water alone. Nicotine sulphate may also be included in the mixture to make a three-fold spray. Do not attempt to combine kerosene emulsion with any other spraying material.

\section{AVOID DAMPING OFF}

One of the most annoying experiences which any gardener can have is to lose a fine batch of seedlings as a result of damping off. This term has been used rather loosely in the past to designate the rotting of young plants and cuttings close to the ground. In reality the trouble is caused by one or an other of a group of related fungus organisms which attack the tissues just at the ground level and destroy them, thus causing the young plant to die. Invariably the trouble is associated with high humidity and lack of ventilation, so the first move in controlling the trouble is to avoid these conditions as far as possible.

The disease producing organism lives in the soil from year to year and frequently draws its nourishment from rotting wood, old manure and any other organic matter which may be in the soil. Soil in which seed is sown should be as free as possible from any of these materials, but should be open and porous so as to permit rapid and thorough drainage. Many gardeners find it a paying proposition to sterilize the soil in which cuttings are to be planted or seed sown. This may be done either with heat or by the use of some chemical such as formalin.

While sterilization is certainly of value, it will not take the place of proper treatment of the seedlings or cuttings. As stated above, high humidity is needed for the development of the disease. On no account should seedlings be sown thickly and then allowed to crowd and become drawn up before they are transplanted. Always aim to keep the leaves and stems dry, particular during the night. Watering should be done early in the day so as to give the plants a chance to dry thoroughly before night comes. Where plants are being grown in a hot bed be sure to give plenty of ventilation. It is better to have the temperature fall somewhat than to keep the frames closed tightly and have the plants suffer for lack of fresh air.

\section{STALK BORERS}

Several species of caterpillars have the insidious habit of boring and tunneling through the stalks and stems of fleshy and thick-stemmed plants such as dahlia, aster, zinnia, lily, hollyhock, peony, goldenglow, phlox, and delphinium.

The stalk borer is the chief offender in the flower garden. Before it is discovered, its work usually progresses to the point where wilting and breaking over of the plant occur. A close examination of plants so affected will disclose a small round hole in the stem, which is the entrance to its burrow. Splitting the stalk lengthwise, one may find the culprit, a slender striped caterpillar which, when fullgrown, is an inch long. The parent months occur in late summer and leave a pupalcase in the burrows. They deposit eggs for the next season's brood on burdock and ragweed, as well as on a variety of other plants.

There is no effective way of poisoning this caterpillar, as it is an internal feeder. The best remedy is clean cultivation and the burning of all stems, roots, and plantremains which are likely to harbor overwintering eggs. The growth of large weeds, specially the giant ragweed, should be prevented or they should be cut, raked together, and burned before the caterpillars contained within them can escape and migrate to garden-plants. 


\section{PUDOR'S \\ Great Iris Price Reductions for 1930 of 50 Finest and Newest Iris Varieties}

\section{When making out your wants notice the following lower prices from our 1929 Iris catalog}

\begin{abstract}
Each
Ambassadeur, reduced to......\$0.50 3 for $\$ 1.00$.

Ann Page, reduced to.......... 1.00 3 for $\$ 2.50$.
\end{abstract}

Asia, reduced to............. 1.50

Avalon, reduced to........... 1.00 3 for $\$ 2.50$.

Apache, reduced to........... 2.00 (We are finding this an exceptionally strong grower.)

Ballerine, reduced to......... .50

Cretonne, reduced to.......... .25

Crusader, reduced to.......... .35

3 for $\$ 1.00$.

Georgia, reduced to........... .35

3 for $\$ 1.00$.

Grevin, reduced to............ . .25

Lady Foster, reduced to........ .50

Lent. A. Williamson, reduced to .35 3 for $90 \mathrm{c}$.

Lord of June, reduced to....... .60

Lord Lambourne, reduced to..... 2.00

Mademoiselle Schwartz ........ $\quad .75$ 3 for $\$ 2.00$.

Mady Carriere, reduced to..... .25

Medrano, reduced to........... .50 3 for \$1.25.

Mildred Presby, reduced to..... 1.00 3 for $\$ 2.50$.

Morning Splendor, reduced to... 1.50

Prospero, reduced to......... .50 3 for $\$ 1.00$.

Queen Caterina, reduced to..... .35 3 for $90 \mathrm{c}$.

Robert W. Wallace, reduced to... 2.50

Roseway, reduced to........... .25 6 for $\$ 1.00$.

San Gabriel, reduced to......... 1.00

Seminole, reduced to.......... .35

3 for $90 \mathrm{c}$.
Shekinah, reduced to........ .25 3 for 50 c.

Sweet Lavender, reduced to...... .50 3 for $\$ 1.00$.

\section{REDUCTION IN THE LIST OF NEW AND OUTSTANDING VARIETIES and}

WILLIAM MOHR'S SEEDLINGS offered on pages 24-A and 25.

HOWEVER, THESE ARE NOT FOR SPRING DELIVERY BUT FALL ONLY.

Each

Aphrodite, reduced to ........\$2.50

Cardinal, reduced to.......... 7.50

Bruno, reduced to........... 5.00

Citronella, reduced to........ 2.50

Conchobar, reduced to........ 4.00

Duke of Bedford, reduced to.... 5.00

Evadne, reduced to........... 2.50

Frieda Mohr, reduced to....... 7.50

Germaine Perthuis, reduced to... 3.00

Gold Imperial, reduced to....... 1.50

Glowing Embers, reduced to.... 2.00

Imperator, reduced to......... 1.00

Mrs. Marion Cran, reduced to... 2.50

Ophelia, reduced to.......... 5.00

Purissima, reduced to ......... 15.00

Souv. De Laetitia Michaud,

reduced to .............. 2.50

Pioneer, reduced to......... 2.50

\section{WM. MOHR'S SEEDLINGS}

Each

Conquistador, reduced to........ $\quad .75$

Ramona, reduced to........... .75

Santa Barbara, reduced to...... 2.50

William Mohr, reduced to...... 9.00

\section{DISCARDED}

Minnehaha, Celeste, Gertrude, Pauline, Zua, Mrs. Neubronner, Caprice Black Knight (or Black Prince)

Blue Boy, Storm Cloud, Ed. Michel, Mme. Paquette, Sherwin Wright, Blue Bird, Trianon, Zouave and Turco. 


\section{INDEX}

Pl. stands for plants

Aconitum (S.)

Aconitum (Pl.)

Aethionema

Ageratum

Alyssum, Annual (S.)

Alyssum, Perennial

Anagallis ( $\mathrm{S}$. )

Anemones (S.)

Anemones (Pl.)

Anchusa (S.)

Anchusa (Pl.)

Antirrhinum ( $S$. )

Aquilegia (S.)

Aquilegia (Pl.)

Armeria (S.)

Aster, Annual (S.)

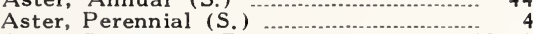

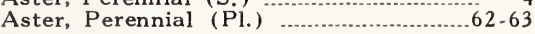

Butterfly Flowers .................................. 55

Browallia (S.) ..................................... 44

Calendula (S.) ....................................... 45

California Poppies .............................. 47

Campanulas ..................................... 10 to $12-40$

Candytuft, Perennial ................................... 10

Candytuf, Annual (S.) ......................... 46

Canterbury Bells (S.) ......................... 10

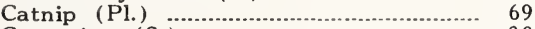

Carnation (S.) (....................................... 30

Cheiranthus (S.) ............................... 0 -40

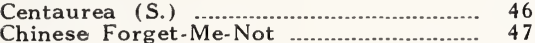

$\begin{array}{ll}\text { Chinese Forget-Me-Not ............................ } & 47 \\ \text { Chinese Lantern (Pl.) } & 35\end{array}$

Clarkia (S.) 45

Columbine

Coneflower-Rudbeckia ......................... 69

Coreopsis (S.) ..................................... 12

Coral Bells (S.) ..................................... 32

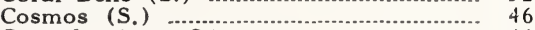

Cynoglossium (S.) ................................. 46

Dahlia Seeds .............................................. 79

Dahlia Tubers ......................................76 to 79

Delphinium Lore .....................................

Delphiniums (S.) .................................22 to 29

Delphiniums (Pl.) ..................................66-67

Dianthus 6-30-40

Didicus-Lace Flowers .......................... 49

Digitalis-Foxglove (S.) ......................... 30

Dimorphotheca (S.) .............................. 47

Eschscholtzia (S.) ................................. 47

Fertilizers ............ 80

Flax, Perennial (S.) ................................ 30

Flax, Perennial (Pl.) .............................. 68

Flax, Annual (S.) 47

Forget-Me-Nots (S.) ........................... 52

Foxglove (S.) ....................................... 30

Gaillardia (S.) ................................... 31

Galega (S.) ........................................... 3

Geum (S.)

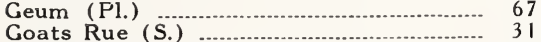

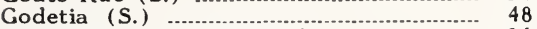

Gypsophelia, Perennial (S.) ................... 31

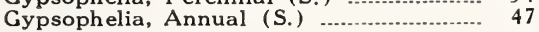

Helianthemum (S.) ............................... 31

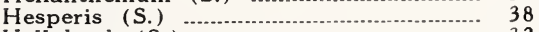

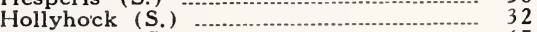

Hollyhock (Pl.) ...................................... 67

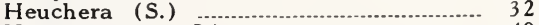

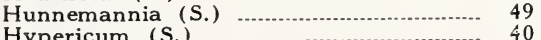

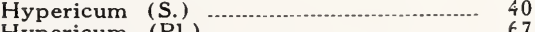

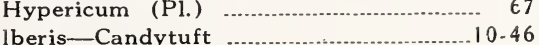

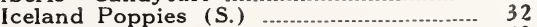

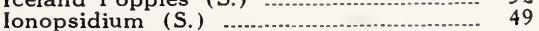

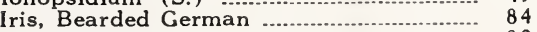

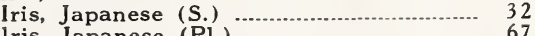

lris, Japanese (Pl.)
S. stands for seeds

Laceflower (S.) 49

Larkspur, Annual (S.)

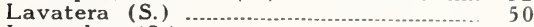

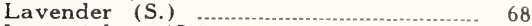

Leptosiphon (S.) 49

Lily Seeds-Regale ......................... 32

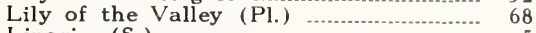

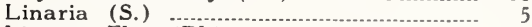

Linum-Flax (Pl.) ................................ 68

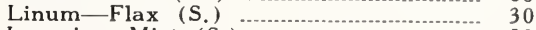

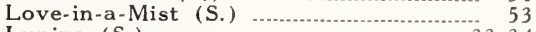

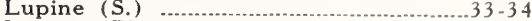

Lupine (Pl.) ........................... 69

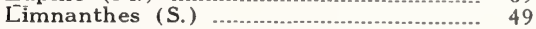

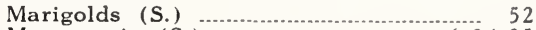

Meconopsis (S.) 6-34-35

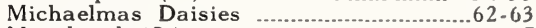

Monshood (S.) .................................... 7

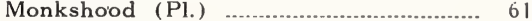

Myosotis (S.) .......................................... 52

Nasturtiums ......................................... 53

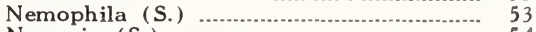

Nemesia (S.) 54

Nepata Mussini (Pl.) ............................... 69

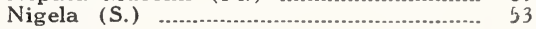

Pansy (S.)

Papaver-Poppies (S.) 35-40

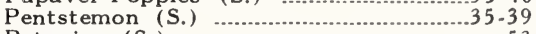

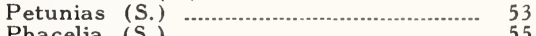

Phacelia (

Phlox, Annual (S.) .............................. 54

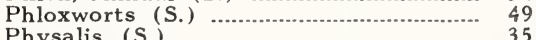

Physalis (S.) …..................................... 35

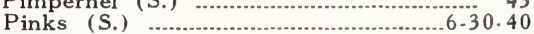

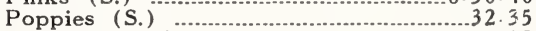

Pyrethrum (S.) .................................... 35

Red Hot Poker (Pl.) ........................... 71

Regal Lily (S.)

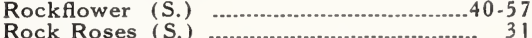

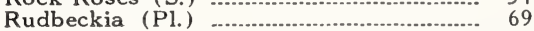

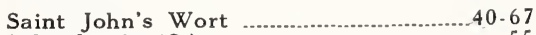

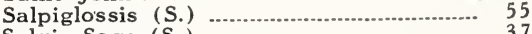

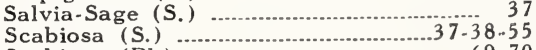

Scabiosa (Pl.)

$69-70$

Schizanthus (S.)

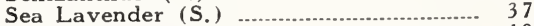

Siberian Wallflower (S.) ......................... 10

Snapdragon (S.) .................................... 8

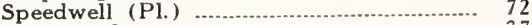

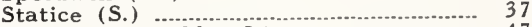

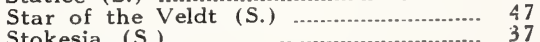

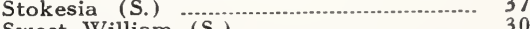

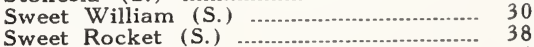

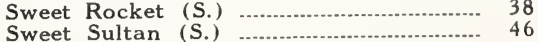

Thalictrum (S.) 37

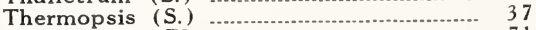

Thermopsis (Pl.) .................................. 71

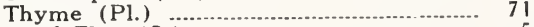

Toad Flax (S.) 5

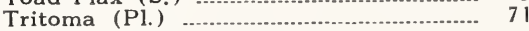

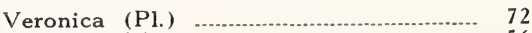

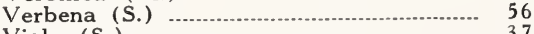

Viola (S.)

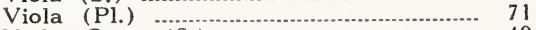

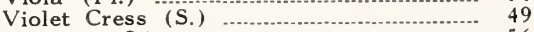

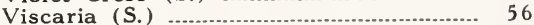

Wahlenbergia (S.) 37

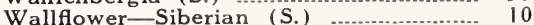

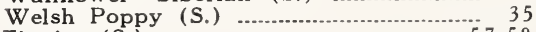

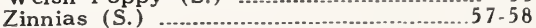




\section{FOR YOUR NOTES}




\section{ORDER SHEET PUDOR'S, Inc. \\ PUYALLUP, WASH.}

PERENNIAL PLANTS-SEEDS AND BULBS

SPECIALIZING IN IRIS, DELPHINIUMS AND LUPINS

Date . . . $\quad \begin{gathered}\text { Please Do Not } \\ \text { Write Here }\end{gathered}$

Your Name

St. and No.

Post Office

County

State

No.

Re'd

Remittance Sent :

State how much money you enclosed

Postage Stamps $\$$

Cash - - $\$$
Money Order \$

Check - - $\$$

By Mail or Express?

When Shall We Send Your Order?

\begin{tabular}{l}
\hline QUANTITY \\
\hline \\
\hline \\
\hline \\
\hline
\end{tabular}

NAME OF PLANTS

PRICE 


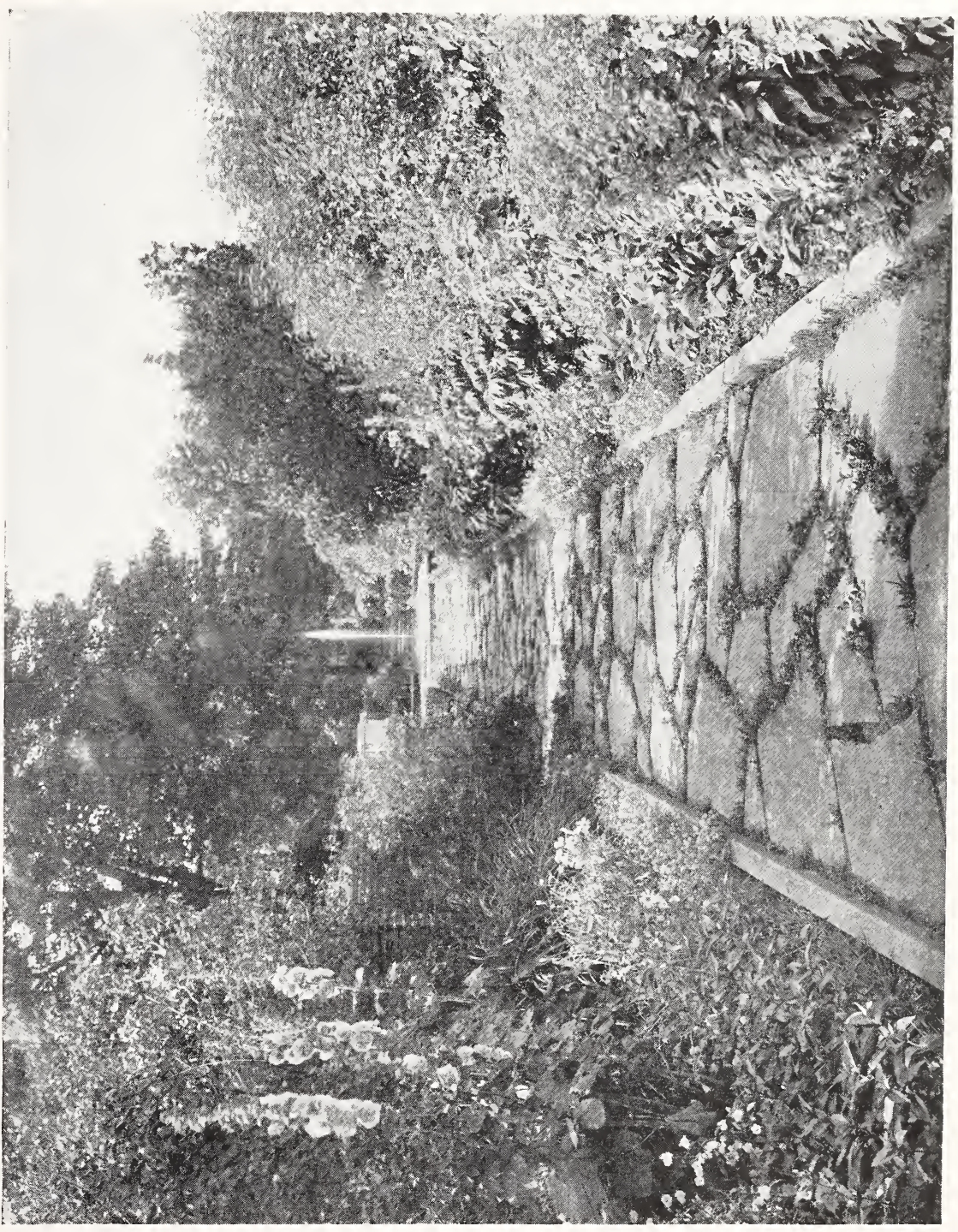

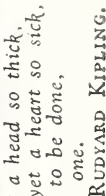

궁

के हैํํㄹ

ปै⿲二丨匕口

ज渮

हีํํ음

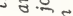

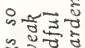

ơ

ㄷํㅇ है

जह

$\because$ 주

पह

है हु

:

है

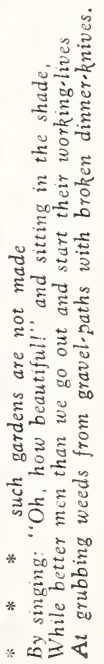




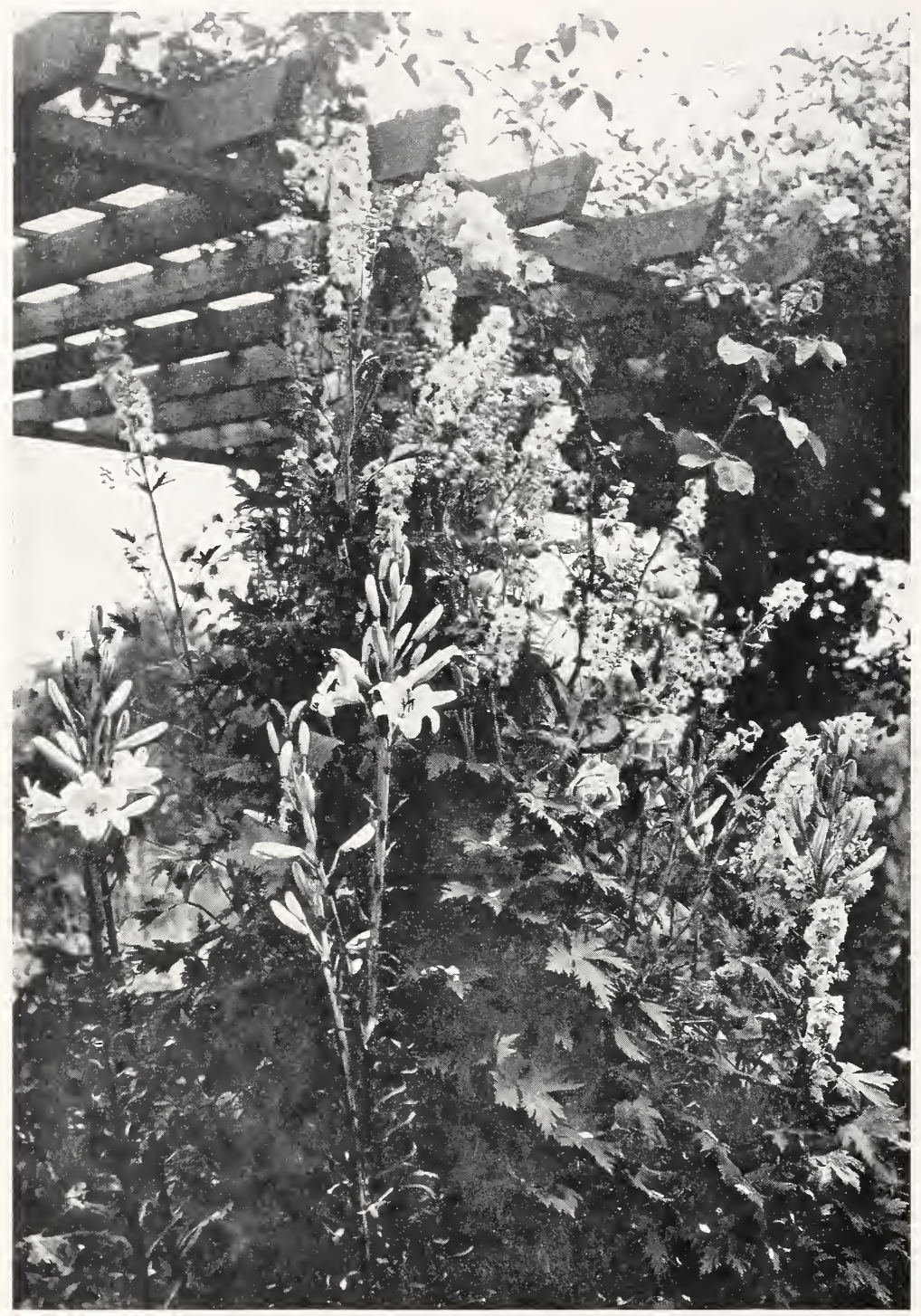

THE best things are nearest - breath in your nostrils, light in your 1 eyes, flowers at your feet, duties at your hand, the path of God just before you. Then do not grasp at the stars, but do life's plain common work as it comes, certain that daily duties and daily bread are the sweetest things of life. 